$1-2013$

\title{
Revolution without Reform: A Critique of Egypt's Election Laws
}

Sahar F. Aziz

Texas A\&M University School of Law, saziz@law.tamu.edu

Follow this and additional works at: https://scholarship.law.tamu.edu/facscholar

Part of the Law Commons

\section{Recommended Citation}

Sahar F. Aziz, Revolution without Reform: A Critique of Egypt's Election Laws, 45 Geo. Wash. Int'I L. Rev. 1 (2013).

Available at: https://scholarship.law.tamu.edu/facscholar/93

This Article is brought to you for free and open access by Texas A\&M Law Scholarship. It has been accepted for inclusion in Faculty Scholarship by an authorized administrator of Texas A\&M Law Scholarship. For more information, please contact aretteen@law.tamu.edu. 


\title{
REVOLUTION WITHOUT REFORM? A CRITIQUE OF EGYPT'S ELECTION LAWS
}

\author{
SAHAR F. AZIZ*
}

\begin{abstract}
This Article compares Egypt's election laws before and after the January 25 Revolution to determine whether the changes are sufficient to produce the structural reforms Egyptians demand. This Article concludes that Egyptian elections processes and institutions remain insufficiently transparent, fail to produce results reflecting the diversity within Egyptian society, and fail to offer all Egyptians-especially women and religious minorities - an equal opportunity to actively participate in governance of their country.

The Article critically assesses recent changes in Egypt's electoral regime and considers whether Egypt had a revolution without reform. The thesis is twofold. First, the post-revolution amendments worsen prospects for Egyptian women and Coptics to be elected to office, thereby further marginalizing them in the public sphere. Such adverse consequences are troubling in light of the significant contributions Egyptian women and Coptics made to the revolution. Second, the limited post-revolution reforms made to election laws are insufficient to produce the sustainable and meaningful democracy sought by Egyptians. Existing post-revolution laws fail to create transparent and independent processes that facilitate a level playing field among candidates and voter confidence in election outcomes.

Nonetheless, in this early stage of the post-revolutionary phase, there is reason for cautious optimism. While Egyptian election laws have been amended for the better since the revolution, more legislative reforms are needed to ensure that future elections are fair, free, and accessible to all Egyptians. Sound election laws are the bedrock of a democracy insofar as they ensure that a dominant party does not extend its rule against the will of the people. As witnessed with the National Democratic Party under the Mubarak regime, laws can be manipulated to guarantee certain electoral outcomes benefitting the dominant party.
\end{abstract}

* Associate Professor, Texas Wesleyan School of Law. Member of the Texas and the District of Columbia bars. J.D., University of Texas School of Law; M.A. in Middle Eastern Studies, University of Texas. Ms. Aziz also serves as the president of the Egyptian American Rule of Law Association, where she supports rule of law projects focused on supporting the Egyptian legal community in post-revolution transitions to democracy. Ms. Aziz thanks Professors Cherif Bassiouni, Tamir Moustafa, Nathan Brown, Mohamad Arafa, Kristen Stilt, and Leila Hilel for their insightful feedback on earlier drafts of this Article. She also thanks Shareif Abdelwahab, Rusty Roeger, Chuck Hill, and Christina Gigliotti for their diligent research assistance in the completion of this Article, as well as the diligence and professionalism of the editors of The George Washington International Law Review. 
In the end, Egypt is at the initial stages of a protracted transition from entrenched authoritarianism to democracy uniquely tailored to Egyptian cultural and religious norms. One year after their historic revolution, Egyptians have made great strides toward that common goal. Whether post-revolution reforms will be structural and produce a complete upheaval of a corrupt political system, as called for by most Egyptians, or merely superficial changes under the false guise of reform will determine the success of this transition. While it is still too soon to predict the outcome, one thing is quite clear-future political leaders who seek to impose authoritarianism do so at their own peril.

\section{Table of Contents}

I. INTRODUCTION.

II. Summary of Egyptian Election Laws and the Electoral Framework.

III. A COMPARISON OF ELECTION LAWS BEFORE AND AFTER

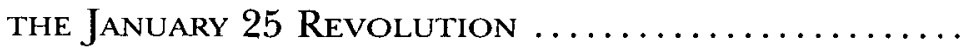

A. Political Rights and the High Elections Commission before the Revolution-Law No. 73 of $1956 \ldots \ldots \ldots$

B. Post-Revolution Amendments to Political Rights and the High Elections Commission-Law No. 73 of 1956....

1. Limited Reforms to the HEC's Membership.

2. Expansion of the HEC's Mandate ...........

C. The People's Assembly before the Revolution-Law No.

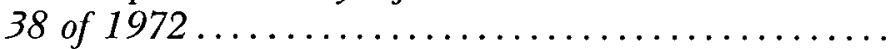

D. Changes to the People's Assembly after the RevolutionLaw No. 38 of 1972 ........................

1. The Proportional Party Representation

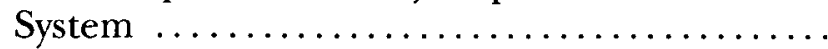

2. The Independent Candidate System ........

3. Creation of a Mixed Electoral System for Parliamentary Elections ...............

E. Minimal Changes to the Shura Council after the Revolution-Law No. 120 of 1980.

1. A Powerless Legislative Body ...............

2. The Same Shura Council after the

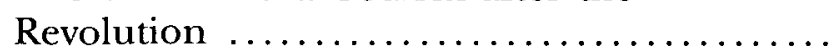

F. Presidential Elections before the Revolution-Law No.

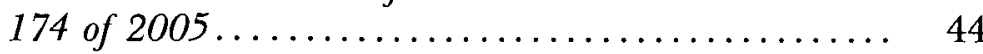

1. The Presidential Nomination Process ....... 44

2. The Presidential Elections Commission ...... 48

G. The Post-Revolution Presidential Elections Law-Law No. 174 of $2005 \ldots \ldots \ldots \ldots \ldots \ldots \ldots \ldots \ldots \ldots . \ldots \ldots$

IV. The Case for Election Reforms in Egypt ........ 55 
A. Inadequate Representation of Women and Coptics in

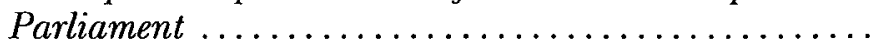

1. Proactive Measures Are Necessary to Ensure Gender Parity in Politics .................

2. Ensuring Proportional Egyptian Coptic Representation in Parliament ..............

B. Bolstering the Independence and Transparency of the Elections Commissions ........................

1. Judicial Elections Commissions Jeopardize the Judiciary's Independence..................

2. A Nontransparent Deliberation Process ...... 70

3. The Need for an Independent Elections Commission Subject to Judicial Review ...... 74

C. Training Judges and Educating Voters ............ 77

V. Conclusion .................................

\section{INTRODUCTION}

Revolution without reform is meaningless. ${ }^{1}$ In the case of Egypt, its people overcame decades of fear and oppression and sacrificed their lives for more than merely overthrowing a dictator. Rather, Egyptians sought to upend an entrenched system of cronyism, nepotism, and pervasive corruption that squandered the future of an entire generation. Millions of youth protested in droves, demanding reforms to the dilapidated education system that required students to bribe public teachers to teach, expressing rage at their inability to obtain employment despite their college degrees, and calling attention to the troubling rise of poverty that was paralyzing their future. ${ }^{2}$ Over the course of a historic eighteen-day revolution, beginning on January 25, 2011 (the January 25 Revolution), ${ }^{3}$ millions of Egyptians took great risks to demand a complete upheaval of the broken system that had failed them.

1. Chibli Mallat et al., Revising Egypt's Constitution: A Contribution to the Constitutional Amendment Debate, 52 HaRv. INT'L L.J. ONLINE 182, 183 (2011) ("A constitutional transition after the ousting of the dictator is the most important task for sealing in law the future of Egypt and the region and for ensuring peaceful political change.").

2. See, e.g., Dina Shehata, The Fall of the Pharaoh: How Hosni Mubarak's Reign Came to an End, ForeigN AfF., May-June 2011, at 26, 26-29 (noting that youth unemployment is highest among those with more education); Raghda El Halawany, A Lesson Learnt the Hard Way in Egypt, Gulf News (Dec. 17, 2010), http://gulfnews.com/news/region/egypt/a-lessonlearnt-the-hard-way-in-egypt-1.729820 (reporting the number of Egyptian students that supplement their education with private tutoring because it is the only way to ensure high performance on exams).

3. See Shehata, supra note 2, at 28-31. 
In a mere eighteen days, Egyptians overthrew the oppressive yoke of a thirty-year despot and dismembered Hosni Mubarak's corrupt National Democratic Party (NDP). ${ }^{4}$ This is just the first step on a long path towards meaningful reform, without which Egypt's January 25 Revolution will be but a glimmer of light in Egypt's long history of authoritarianism. The fight for Egypt's future has now moved from the streets to the mechanisms and structures that promote self-governance, government transparency and accountability, and a society governed by the rule of law. ${ }^{5}$

Most recently, the revolution has moved to the courts as the Muslim Brotherhood ${ }^{6}$ and the Supreme Council of the Armed Forces (SCAF) - which assumed executive power for eighteen months in Egypt following Mubarak's fall-compete to co-opt the judiciary to execute their respective agendas. ${ }^{7}$ For example, Egyptians viewed with suspicion the Supreme Constitutional Court's (SCC) ${ }^{8}$ June 12, 2012, ruling calling for the dissolution of a Muslim Brotherhooddominated parliament. ${ }^{9}$ Many Egyptians suspected the SCAF had improperly meddled with the Court's deliberations. ${ }^{10}$ Regardless

4. See id. at 26-27, 29-32.

5. See Mallat et al., supra note 1 at 183-84, 187.

6. The Muslim Brotherhood began as a social and political movement in 1928 that initially accepted the use of violence to implement its political and religious ideology wherein government policies and practices are based on Islamic principles and values. See Profile: Egypt's Muslim Brotherhood, BBC (June 26, 2012), http://www.bbc.co.uk/news/ world-middle-east-12313405. During the 1980s, the Muslim Brotherhood denounced violence as a political tool and instead attempted to work through the political system as another stakeholder in the political process. See id. Following Mubarak's resignation in February 2011, the Muslim Brotherhood formed the Freedom and Justice Party and ran political candidates for parliament. See id. After decades of state sponsored suppression, detention, and torture of Muslim Brotherhood officials, the Freedom and Justice Party won nearly half of the seats in the People's Assembly in the first post-revolution parliamentary elections, and their 2012 presidential candidate, Mohamed Morsi, was elected to the presidency. See id.

7. David D. Kirkpatrick, Blow to Transition as Court Dissolves Egypt's Parliament, N.Y. Times (June 14, 2012), http://www.nytimes.com/2012/06/15/world/middleeast/newpolitical-showdown-in-egypt-as-court-invalidates-parliament.html (discussing Supreme Council of the Armed Forces' (SCAF) possible involvement in the Supreme Constitutional Court's (SCC) ruling to dissolve parliament).

8. The SCC serves as the highest court of the land in Egypt. Mohamed S.E. Abdel Wahab, An Overview of the Egyptian Legal System and Legal Research, § 6.2, GLobaLex (Oct. 2012), http://www.nyulawglobal.org/Globalex/Egyptl.htm. The Court is empowered to: (1) determine the constitutionality of laws and regulations; (2) decide on jurisdiction disputes between judicial bodies; and (3) interpret the laws issued by the Legislative Authority and the decrees issued by the Head of the State in case of any divergence with respect to their implementation. Id.

9. See Kirkpatrick, supra note 7 (reporting that the SCC's ruling to dissolve parliament was "condemned as a 'coup' by Islamists, liberals and scholars").

10. See id. 
of the veracity of such claims, the SCC's credibility and independence has been called into question. Indeed, in an act of defiance, President Morsi directly challenged the ruling by instructing the parliament to resume its work. ${ }^{11}$ Meanwhile, Morsi appealed the SCC's decision to the Highest Administrative Court (HAC). ${ }^{12}$ Although the HAC dismissed the appeal for lack of jurisdiction, as required by law, the case triggered increased suspicions about the independence of the judiciary and more specifically the sitting judges' loyalties to the former Mubarak regime and the SCAF. ${ }^{13}$

This Article examines the recent changes to Egypt's electoral regime in order to assess whether Egypt is experiencing a revolution without reform or a revolution that is shifting the country's trajectory towards a meaningful democracy. The Article's thesis is twofold. First, the post-revolution amendments worsen prospects for Egyptian women and Coptics (Copts) to be elected to office, thereby further marginalizing them in the public sphere. ${ }^{14}$ Such adverse consequences are troubling in light of the significant contributions Egyptian women and Copts made during the revolution. Second, the limited reforms made to election laws post-revolution are insufficient to produce the sustainable democracy sought by Egyptians. Existing post-revolution laws fail to create an adequately transparent and independent process that facilitates a level playing field among candidates and voter confidence in the political system. ${ }^{15}$

11. Mohamed Fadel Fahmy, Egyptian Parliament to Convene Tuesday, Official Says, CNN (July 9, 2012), http://www.cnn.com/2012/07/08/world/meast/egypt-politics/index.html (explaining that Morsi's order to reinstate parliament puts him at odds with the SCAF).

12. Int'l Found. for Electoral Sys., Elections in Egypt: Implications of Recent Court Decisions on Electoral Framework 7 (2012), available at http://www.ifes.org/ / media/Files/Publications/White\%20PaperReport/2012/Egypt_SCC_Decisions_August9. pdf (explaining the process of appeals surrounding the dissolution of parliament).

13. See id.; Kirkpatrick, supra note 7 .

14. In a statement, U.S. Ambassador for Global Women's Issues Melanne Verveer said the following:

[I]n Egypt women have pretty much been precluded from even the transitional governance that has been going on there. There has been a taking back of the quota that would have had more women in the parliament. And there is the potential that so much of the progress that they have made will be rolled back.

Amar C. Bakshi, Global Women's Ambassador on the Arab Spring, Islam, Politics and Contraception, CNN WORLD (Mar. 8, 2012), http://globalpublicsquare.blogs.cnn.com/2012/03/08/ state-department-official-defends-access-to-family-planning-abroad/.

15. See, e.g., Leila Fadel \& Ingy Hassieb, Official Results Confirm Egyptians Face a Stark Choice in Presidential Election, WasH. Post (May 29, 2012), http://www.washingtonpost. $\mathrm{com} /$ world/middle_east/official-results-confirm-egyptians-face-a-stark-choice/2012/05/ 28/gJQA30fxwU_story.html (expressing concerns with voter rigging and improper interference by the military in favor of Ahmed Shafiq). 
In this early stage of the post-revolutionary phase, there is reason for cautious optimism. However, while Egyptian election laws have been amended for the better since the revolution, more legislative reforms are needed to ensure that future elections are fair, free, and accessible to all Egyptians. ${ }^{16}$ Sound election laws are the bedrock of a democracy insofar as they ensure that a dominant party does not extend its rule against the will of the people. As witnessed with the NDP under the Mubarak regime, laws can be manipulated to guarantee certain electoral outcomes that further entrench the dominant party. ${ }^{17}$

Accordingly, this Article posits that post-revolution amendments to Egypt's election laws, while a step in the right direction, remain insufficient to produce a society where parliament represents all Egyptians, including women and Copts. The Article examines how the laws governing elections for the lower house of parliament (the People's Assembly), the upper house of parliament (the Shura Council), and the president affect the citizenry's ability to monitor elections and challenge electoral irregularities. Integral to this examination is a critique of the laws that govern Egypt's two election monitoring and regulation oversight authorities-the High Elections Commission (HEC) and the Presidential Elections Commission (PEC).

This Article compares the laws before and after the revolution to determine whether the changes implemented thus far are suffi-

16. Mallat et al., supra note 1 , at 185-86 ("[SCAF] aspires to guarantee a peaceful transition of authority within a free and democratic system that allows for the assumption of authority by a civilian and elected authority to govern the country and the building of a democratic and free state.") (statement by SCAF in its Communique Number 4 on February 12,2011$)$.

17. See, e.g., Heba Saleh, Egyptian Steel Magnate Jailed for Corruption, Fiv. Times (Sept. 15, 2011), http://www.ft.com/cms/s/0/8dc45c06-dfa2-1 le0-845a-00144feabdc0.html\# axzzloGct3i3L (highlighting the case of Ahmed Ezz, who monopolized the steel industry by holding more than $60 \%$ of the market share). Ahmed Ezz was a close associate of Gamal Mubarak, the influential son of the former president who was widely seen to be preparing to succeed his father. Id. Commentators often described him as "the engineer of succession"-a reference to his presumed role in preparing the grounds for the son's political ambitions. Id. In 2011, an Egyptian Criminal Court sentenced Ezz to ten years in prison on corruption charges. Mohamed A. Arafa, Towards a Culture for Accountability: $A$ New Dawn for Egypt, 5 Phoesix L. Rev. 1,12 n.60 (2011). In 2012, he was convicted before a second Egyptian Criminal Court on charges of money laundering and sentenced to an additional seven years in prison and fined nearly twenty billion Egyptian pounds (approximately three billion dollars). Egyptian Steel Magnate Ahmed Ezz Convicted, BBC (Oct. 4, 2012), http://www.bbc.co.uk/news/world-middle-east-19830922; see also Mallat et al., supra note 1, at 182, 184 (highlighting Mubarak's use of Article 139 on January 29, 2011 to appoint a vice-president after three decades of not having one to preempt the Speaker of the People's Assembly from using Article 84 to demote Mubarak from the presidency). 
cient to produce the structural reforms Egyptians demand. At first blush, some of the post-revolution changes appear constructive; however, a more in-depth analysis reveals the structural flaws in the purported reforms. A prime example is the transition of the HEC and PEC's membership to judges. ${ }^{18}$ While judges are preferable to politicians, who were historically handpicked by the former NDP, their immersion into the trenches of the electoral process jeopardizes their independence. Rather than serving as front line arbitrators in partisan electoral disputes, judges should be limited to reviewing decisions issued by independent elections commissions. Judicial review can be one of the many checks that ensure the elections commissions are in fact independent. Moreover, appellate review of HEC and PEC findings may be viewed as less credible when it involves review of fellow judges' announcements of election results as opposed to an independent election commission. ${ }^{19}$ The Article concludes that Egyptian electoral processes remain insufficiently transparent, fail to produce results reflecting the diversity within Egyptian society, and fail to offer all Egyptians, especially women and religious minorities, an equal opportunity to actively participate in governance of their country.

\section{Summary of Egyptian Election Lawis and the ELECTORAL FramewORK}

Four statutory laws and two constitutional provisions govern Egypt's complicated electoral process. ${ }^{20}$ Article 88 of the abrogated 1971 Egyptian Constitution, as adopted and amended in Article 39 of the 2011 Constitutional Declaration, establishes the legal framework for Egypt's electoral system. ${ }^{21}$ Article 39 stipulates

18. See infra Parts III.B, III.F for a detailed discussion of the post-revolution changes to the HEC and PEC, respectfully.

19. Foutouh El Chazl \& Karim El Chazli, Euro-Mediterranean Human Rights Network, EGYPT: The INDEPENDENCE OF THE Judiclary 27-29 (Susan Sharpe trans., 2010) (noting some reform-minded judges' fears prior to the revolution that the falsification of electoral results would make people lose confidence in the judiciary if the judges were constitutionally obliged to oversee the electoral process).

20. See generally Democracy Reporting Int'L, Comprehensive Assessment of Ecypt's Electoral Framework 4-7, 9-27 (2011) [hereinafter Democracy Reporting Int'L, ComPREHENSIVE AsSESSMENT] (describing post-revolution changes to Egyptian election law through July 11, 2011 in detail).

21. See Constitutional. Declaration of the Arab Republic of Egypt art. 39, Mar. 30, 2011 [hereinafter Constitutional Declaration], translated in Constitutional Declaration 2011, Ecyptian Gov't Servs. Portal, www.egypt.gov.eg/english/laws/constitution/ default.aspx (last visited Jan. 7, 2012) (adopting Article 88 in part); ConSTITUTION OF THE Arab Republic of Egrpt art. 88, Sept. 11, 1971, as amended, May 22, 1980, May 25, 2005, March 26, 2007. 
"the law shall determine the conditions that must be met for members of the People's Assembly and Shura Council and shall stipulate electoral and referenda provisions." ${ }^{22}$ It mandates passage of legislation that regulates the electoral process, including the establishment of the HEC to supervise parliamentary elections. ${ }^{23}$ Similarly, Article 76 of the abrogated 1971 Egyptian Constitution, as amended in 2005 and adopted in part as Article 28 of the 2011 Constitutional Declaration, establishes the PEC to supervise presidential elections. ${ }^{24}$ Laws No. 173 and 174 of 2005 delineate the authority the HEC and PEC, respectively, as supervisory electoral bodies. ${ }^{25}$ In addition, Law No. 38 of 1972 governs elections to the People's Assembly, ${ }^{26}$ while Law No. 73 of 1956 defines voter rights and responsibilities. ${ }^{27}$

This constitutional framework was dissolved when the SCAF suspended Egypt's 1971 Constitution on February 13, 2011.28 In its place, the SCAF adopted a Constitutional Declaration on March 30, 2011, which serves as Egypt's interim constitution until a new one is drafted by a one-hundred-member constitutional committee selected by parliament. ${ }^{29}$ The Constitutional Declaration adopts

22. Constitutional Declaration, supra note 21 , art. 39.

23. See id.; Int'l Found. for Electoral Sys., Elections in Egypt: Structure and Responsibitities of the Higher Elections Commission, and Other Issues Concerning Electoral Operations 2-3 (2011), available at http://www.ifes.org/Content/Publications/White-Papers/2011/ /media/Files/Publications/White\%20PaperReport/2011/ 2011_Egypt_Briefing_Paper_III_Political_Rights.pdf [hereinafter STRUCTURE AND RESPONSibilities of the Higher Elections Commission] (explaining that the High Elections Commission (HEC) is responsible for elections of the People's Assembly and the Shura Council and referenda, as established through legislation in Article 3 bis of Law 73/1956).

24. Kristen A. Stilt, Constitutional Authority and Subversion: Egypt's New Presidential Election System, 16 IND. INT'L \& Comp. L. Rev. 335, 343-44 (2006).

25. Id. at $350,353,363-65$. Law No. 173 of 2005 replaced the previous law regulating the HEC, Law No. 73 of 1956 . See id. at 353 n.78.

26. See Law No. 38 of 1972 (Concerning the People's Assembly), Al-Jarida Al-Rasmiyya, 28 Sept. 1972 (Egypt).

27. Democracy Reporting Int'L, Comprehensive Assessment, supra note 20, at 9.

28. Nathan J. Brown \& Kristen Stilt, A Haphazard Constitutional Compromise, CARNeGie Endowment for INT'L PEACE (Apr. 11, 2011), http://carnegieendowment.org/2011/04/ 11/haphazard-constitutional-compromise/2q1 (criticizing SCAF for unilaterally abrogating the 1971 Constitution through an announcement on Facebook despite a referendum held two weeks earlier that approved eight amendments to the 1971 Constitution instead of abrogating it completely); Mallat et al., supra note 1, at 182, 184 (discussing SCAF's proclamation announcing that it was suspending the Constitution and governing the country for six months or until elections were held for the People's Assembly, Shura Council, and President); see also Arafa, supra note 17, at 18-21.

29. For an in-depth analysis of the Constitutional Declaration, see Brown \& Stilt, supra note 28. See also Nathan Brown, U.N. Dev. Program, Constitutional Rebirth: Tunisia AND Egypt Reconstruct Themselves 5-7, 12-14, 17-20 (2011), available at http://www. arab-hdr.org/publications/ahdr/Tunisia\&Egypt.pdf. For an in-depth analysis of the Tem- 
Articles 39 and 76, among others, of the abrogated 1971 Constitution as Articles 39 and 27-28, respectfully, thus leaving intact the pre-revolution electoral framework and attendant laws. ${ }^{30}$ It is worth noting that the Constitutional Declaration was unilaterally issued by the SCAF absent any public debate on the numerous provisions not included in Egypt's March 2011 public referendum. ${ }^{31}$ Notwithstanding the serious legitimacy concerns arising from such an undemocratic process, Egyptians have begrudgingly accepted it with the understanding that a new constitution will soon replace it through a democratic process. ${ }^{32}$ While the legitimacy of the Constitutional Declaration is relevant to electoral laws, it is beyond the scope of this Article, and thus will not be addressed in depth. ${ }^{33}$

Much of the debate about post-revolution elections reform is centered on amendments to four laws governing elections and elections monitoring. ${ }^{34}$ Accordingly, Part III of this Article describes post-revolution changes to these laws to provide the reader a comparative framework with which to assess Egypt's electoral system. Part IV then provides a critique of these post-revolution changes as a segue to specific recommendations for further

poral Constitutional Declaration and the eight constitutional amendments, see Arafa, supra note 17, at 18-21. But see Constitutional DECLARATION, supra note 21, art. $60 \mathrm{~B}$ (authorizing SCAF to appoint the constitutional committee and "if the constituent assembly encounters an obstacle that would prevent it from completing its work, the SCAF within a week will form a new constituent assembly to author a new constitution within three months from the day of the new assembly's formation").

30. See Constitutional. Declaration, supra note 21 (adopting Articles 1, 2, 3, 4, 8, $40,41,42,44,45,46,47,48,54,55,56,57,58,61,66,67,68,69,71,72,73,75,76$ (in part)), 77 (in part), 88 (in part), 148 (in part), 189 (in part)).

31. Michael Wahid Hanna, Mapping Egypt's Electorate, Foreign Policy (May 15, 2012), http://mideast.foreignpolicy.com/posts/2012/05/15/mapping_egypts_electorate (offering context for the public's growing impatience with the transition and the illegitimacy and undemocratic adoption of the SCAF's March 2011 Constitutional Declaration); see also Kristina Kausch, The Muslim Brotherhood, Post-Election Scenarios and Policy Options in Egypt: A European Perspective, in E.U. Inst. for Sec. Studies, Egyptian Democracy and the Muslim BrotherhoOd 6, 10 (Esra Bulut Aymat ed., 2011) (reporting that SCAF's adoption by decree of new electoral legislation contradictory to amendments approved by the referendum without any consultation led to a public outcry by political groups and parties).

32. Kausch, supra note 31, at 10.

33. Id.; see also Donald J. Kochan, You Say You Want a (Nonviolent) Revolution, Well Then What? Translating Western Thought and Institution Building for Freedom in Governments Emerging Out of Peaceful Chaos, 114 W. VA. L. Rev. 897, 902 (2011) (stating that one risk is that democratic elections do not follow a nonviolent revolution and instead some nondemocratic regime emerges).

34. Mallat et al., supra note 1, at 188 (arguing that either the Constitutional Amendment Committee or the SCAF should be encouraged to confirm that the transition to democracy and the holding of free and fair elections will be led by the judiciary). 
reforms necessary to transform elections into a fully transparent, fair, and accessible process for all Egyptians.

While post-revolution changes to election laws are an improvement, they fail to ensure religious minorities and women are adequately represented in elected office in accordance with its international commitments. ${ }^{35}$ Egypt is a state party to the International Covenant on Civil and Political Rights, the International Covenant on Economic, Social and Cultural Rights, the UN Convention on the Elimination of all Forms of Discrimination Against Women (CEDAW), and the African Charter on Human and Peoples' Rights. ${ }^{36}$ By signing these treaties, Egypt has committed to providing equal opportunity for women and minorities to get elected into office. ${ }^{37}$ Specifically, Article 7 of CEDAW obligates Egypt to:

$[\mathrm{T}]$ ake all appropriate measures to eliminate discrimination against women in the political and public life of the country and, in particular, shall ensure to women, on equal terms with men, the right: ...

(b) to participate in the formulation of government policy and the implementation thereof and to hold public office and perform all public functions at all levels of government. ${ }^{38}$

In February 2010, the UN Committee on the Elimination of Discrimination Against Women, in its concluding observations called on Egypt "to adopt temporary special measures . . . in order to accelerate the full and equal participation of women in public and political life ... [and] to take the necessary measures to secure the participation of women in the various phases of the electoral process," and "to modify, or repeal, without delay and within a clear

35. Khaled A. Beydoun, Fast Tracking Women into Parliamentary Seats in the Arab World, 17 Sw. J. INr'L L. 63, 73 (2011) (referencing the opposition and ultimate elimination of the quota for women in post-revolution parliament seats).

36. Ratification of International Human Rights Treaties: Egypt, U. Minn. Hum. RTs. Libr., http://www.umn.edu/humanrts/research/ratification-egypt.html (last visited Jan. 8, 2013).

37. For example, Article 3 of the Convention on the Elimination of all Forms of Discrimination Against Women (CEDAW) states the following:

$[P]$ arties shall take in all fields, in particular in the political, social, economic and cultural fields, all appropriate measures, including legislation, to ensure the full development and advancement of women, for the purpose of guaranteeing them the exercise and enjoyment of human rights and fundamental freedoms on a

basis of equality with men.

Convention on the Elimination of All Forms of Discrimination Against Women art. 3, Dec. 18, 1979, 1249 U.N.T.S. 13, 19 I.L.M. 33 (1980). Egypt became a signatory party to CEDAW on July 16, 1980. Id.

38. Id. art. 7 . 
time frame, discriminatory legislation." ${ }^{39}$ In response, Egypt adopted a quota to appoint sixty-four women in the People's Assembly, as discussed in more detail in Part IV(A)(1).

In addition, current laws fail to create a transparent and independent process that facilitates a level playing field and voter confidence in the system. ${ }^{40}$ Thus, the record high voter turnout for the 2011 and 2012 parliamentary elections, attributed mostly to the optimism from Egypt's historic revolution, is likely to decline as enthusiasm fades and Egyptians embark on the difficult project of nation-building and navigating the transition to democracy. ${ }^{41}$ Accordingly, the parliament should reform the laws to ensure all Egyptians are fully enfranchised and have an equal opportunity to partake in political life.

\section{A Comparison of Election LaWS before AND AFTER the JANUARY 25 ReVOLUTION}

For the most part, Egypt's pre-revolution electoral system remains intact. The electoral system that allowed Mubarak and the NDP to retain a three-decade grip on power continues to determine how the president and members of parliament are elected. ${ }^{42}$ Despite repeated calls for systemic changes to Egypt's electoral framework, ${ }^{43}$ the SCAF has limited reforms to minor, incremental changes. ${ }^{44}$ While any progress towards reforming Egypt's laws is a

39. Concluding Observations of the Committee on the Elimination of Discrimination Against Women, para. 16, 30, U.N. Doc. CEDAW/C/Egy/Co/7 (Feb. 5, 2010) [hereinafter Concluding Observations].

40. Mallat et al., supra note 1 , at 184 (arguing for transparency).

41. Stilt, supra note 24, at 337; Frank Richardson, Rule of Law: An Elusive Panacea, INT'L BAR Ass'n, http://www.ibanet.org/Article/Detail.aspx?ArticleUid=e780194c-fa58-47 27-a964-19945729c282 (last visited Jan. 8, 2013); Mallat et al., supra note 1, at 183 ("All Egyptians in good faith, and those who support them on the bumpy and difficult road to democracy, are seeking to build institutional change into the neglected and distorted promise of the Constitution.").

42. Stilt, supra note 24, at 335-36 (discussing the leverage Mubarak had in the elections based on the election laws that he helped draft).

43. Khalil Al-Anani, Egypt's Souring Transition, Open Democracy (Oct. 19, 2011), http://www.opendemocracy.net/khalil-al-anany/egypt\%E2\%80\%99s-souring-transition;

Egypt Panel Proposes Limit to Presidential Term, Al Arabrya News (Feb. 26, 2011), http://www. alarabiya.net/articles/2011/02/26/139356.html (noting that SCAF instructed Constitutional Amendment Committee to "amend all articles as it sees fit to guarantee democracy and the integrity of presidential and parliamentary elections" in reforming the 1971 Constitution); Mallat et al., supra note 1, at 190.

44. See Law No. 38 of 1972 (Concerning the People's Assembly), Al-Jarida Al-Rasmiyya, 28 Sept. 1972 (Egypt); Decree Law No. 120 of 2011 (To Amend Provisions of Law No. 38 of 1972 on the People's Assembly and Law No. 120 of 1980 on the Shura Council), 27 Sept. 2011 (Egypt). 
welcome change after three decades of stagnation, current postrevolution reforms do not go far enough. The entities tasked with election oversight and monitoring still lack sufficient independence and authority to function in a manner that ensures all Egyptians are adequately represented in the parliament. ${ }^{45}$ As such, current election laws adversely affect women and religious minorities by denying them meaningful opportunities to be elected to the parliament. Accordingly, this Section provides a comparative framework through which to examine pre- and post-revolution election laws.

Section A summarizes the pre-revolution laws regarding voters' political rights and the role of the HEC in monitoring parliamentary elections. Section B summarizes the post-revolution amendments to these laws and their impact on election transparency, accessibility, and oversight of the electoral process. Of the various post-revolution changes to election laws, those pertaining to the HEC are arguably the most progressive towards ensuring independent elections oversight - a crucial prerequisite for avoiding abuse by prospective dominant parties.

Sections C and D analyze how post-revolution amendments changed the process by which candidates run for office. While some of the most significant shortcomings in the laws remain unchanged, the introduction of a closed list system ${ }^{46}$ steers voters towards electing political parties that presumably select candidates competent to hold office, if only to increase the chances of the political party winning the next election. This is a welcome change in a country where political office historically went to those with wealth and political connections, instead of experienced candidates committed to public service.

Section E compares the pre- and post-revolution laws governing Shura Council elections to illustrate the minimal changes made to Law No. 120 of 1980. Due to a lack of legislative authority, the Shura Council is often criticized as an unnecessary, elitist institution. ${ }^{47}$ It remains to be seen whether the Shura Council will transition into a traditional higher chamber of parliament that works in conjunction with the lower house to promulgate laws. ${ }^{48}$

45. Chazli \& Chazli, supra note 19 , at 29.

46. Democracy Reporting INT'L, Comprehensive Assessment, supra note 20, at 20-22 (noting and elaborating on introduction and complications of the closed list system).

47. Mallat et al., supra note 1 , at 203.

48. At the time of the writing of this Article, reforming the Shura Council is not a priority in Egypt's national reform agenda. Brown \& Stilt, supra note 28 ("The declaration also keeps the Consultative Council (Majlis al-Shura), the upper house of the Egyptian 
Sections $\mathrm{F}$ and $\mathrm{G}$ examine the presidential nomination and election process in place before and after the January 25 Revolution, respectively. For over three decades, the laws governing this process highly favored the ruling NDP, virtually guaranteeing each Mubarak victory. ${ }^{49}$

\section{A. Political Rights and the High Elections Commission before the Revolution-Law No. 73 of 1956}

In 1952, a military committee of junior army officers, known as the "Free Officers Movement," overthrew the monarchy of King Farouk, ending nearly a century of British colonial rule and ushering in a new era in modern Egyptian politics. ${ }^{50}$ The Free Officers Movement, led by Lieutenant General Mohamed Naguib and subsequently by Gamal Abdel-Nasser, imposed a new Egyptian Constitution in 1956.51 The 1956 Constitution established a republican system of government with a "National Assembly" as its unicameral parliament. 52

The National Assembly passed Law No. 73 of 1956, which defines the rights and responsibilities of citizens and government entities in the electoral process. ${ }^{53}$ Law No. 73 of 1956 also establishes the HEC. ${ }^{54}$ The HEC is a public institution legally recognized as a

parliament created in 1980 with few functions other than to serve as a check on the lower People's Assembly in the unlikely event it began to show independence. And yet the declaration does not include the list of legislative areas that require the Consultative Council's approval before the People's Assembly can act, suggesting the Council has no binding power vis-à-vis the People's Assembly.").

49. Stilt, supra note 24, at 348-53 (detailing the ways Mubarak and the National Democratic Party (NDP) entrenched the presidential election process via the ways to become a candidate and election monitoring).

50. See Tamir Moustafa, Law Versus the State: The Judicialization of Politics in Egypt, $28 \mathrm{~L}$. \& Soc. Inquiry 883, 888 (2003). The British colonized Egypt in 1882. See Richardson, supra note 41.

51. See Michele Dunne, Carnegie Endowment for Int'l Peace, Evaluating EgypTIAN REFORM 4 (2006), available at http://www.carnegieendowment.org/files/CP66. Dunne.FINAL.pdf.

52. Constitution of the Arab Republic of Egrpt, 23 June 1956. The National Assembly was subsequently turned into a bicameral parliament following the enactment of Law No. 120 of 1980, creating the upper-house Shura Council. See Law No. 120 of 1980 (Concerning the Shura Council), Al-Jarida Al-Rasmiyya, 3 July 1980 (Egypt).

53. Law No. 73 of 1956 (Concerning the Exercise of Political Rights), Al-Jarida AlRasmiyya (Egypt).

54. Article 1 of Law No. 73 of 1956 grants all Egyptians age eighteen years and older, except those serving as police and military personnel, the right and duty to vote in all presidential, parliamentary, and local council elections. Id. art. 1. Article 2 prohibits certain persons from voting, including persons (1) convicted of a criminal act, unless they have been rehabilitated; (2) whose property was confiscated under a judgment by the Court of Ethics, for a period of five years after issuance of the confiscation order; (3) 
juridical person domiciled in Cairo. ${ }^{55}$ The HEC supervises elections of the People's Assembly, Shura Council, and national referenda. ${ }^{56}$ In theory, the HEC is supposed to serve as an independent body comprised of judges and politically unaffiliated individuals who ensure that parliamentary elections are free, fair, and transparent. Pursuant to this mandate, the HEC's pre-revolution authority included: (1) promulgating rules for developing election rosters and their revision, screening, and updating methods; (2) recommending rules for determining electoral constituencies; (3) promulgating general rules for regulating election campaigns; (4) increasing public awareness and orientation efforts pertaining to elections; (5) developing guidelines for the electoral process; (6) monitoring compliance with codes of ethics related to elections; (7) declaring the results of elections and referenda; and (8) issuing opinions on draft laws relating to elections. ${ }^{57}$

Before the revolution, the HEC was comprised of the following members: (1) the Minister of Interior, as chair; (2) three serving members of the judiciary with a rank of deputy heads of the Supreme Court of Cassation or its equivalent; and (3) six public figures not affiliated with any political parties, four of whom are chosen by the People's Assembly, including at least two former members of the judiciary. ${ }^{58}$ The High Judicial Council selected the three serving judiciary members and three additional equally ranked judges as reserve members. ${ }^{59}$ The Shura Council selected the final two members, at least one of whom had to be a former member of the judiciary. ${ }^{60}$ Both chambers of parliament selected six public figures as reserve members, according to the criteria set for the serving members. ${ }^{61}$ All six individuals served a six-year

sentenced to prison for specified crimes; and (4) dismissed from the civil service or public sector "for disgraceful reasons," for a period of five years after dismissal. Id. art. 2. Article 3 suspends the political rights of persons (1) placed under interdiction; (2) treated for mental illnesses, during their treatment; or (3) declared bankrupt, for five years as of the date of declaration, unless they were previously rehabilitated. Id. art. 3.

55. Id. art. 3(bis) (a).

56. Id. art. 3 (bis) (f) (1).

57. Stilt, supra note 24 , at 364-65.

58. Democracy Reporting Int'l, The Arab Republic of Ecypt: Assessment of the Electoral Framework 26 (2007) [hereinafter Democracy Reporting Int'l, The Arab RePUblic of EGYPT].

59. Id.

60. Id.

61. See Law No. 73 of 1956 (Concerning the Exercise of Political Rights), Al-Jarida AlRasmiyya, art. 3(bis) (Egypt). 
term. ${ }^{62}$ The six public figures were historically loyalists to the NDP whose partisanship undermined the credibility of the HEC. ${ }^{63}$

After significant pressure from civil society organizations and a landmark SCC ruling in 2000 that mandated judicial supervision of elections, ${ }^{64}$ Egyptian parliamentary elections were required by law to be monitored by judges. ${ }^{65}$ Not to be thwarted by the SCC, the Mubarak regime assigned oversight of the judicial monitors to the Ministry of Interior and the Ministry of Justice, both directly controlled by the executive. ${ }^{66}$ To make matters worse, the judicial personnel assigned to monitor polling stations were from the prosecutor's office and the State Lawsuits Authority, both of which are controlled by the executive branch. ${ }^{67}$ Thus, the executive branch sought to use the judiciary's reputation and prestige to validate sham elections. ${ }^{68}$ Based on this checkered history, the membership of the HEC was overhauled after the revolution to make it a purely judicially-run entity that oversaw other judges monitoring the polls. ${ }^{69}$

Pre-revolution, Law No. 73 of 1956 required the HEC to establish a permanent Technical Secretariat with an independent budget whose "terms of reference" (i.e., its structure and objectives) are determined by the HEC chair. ${ }^{70}$ The HEC's Technical Secretariat held significant influence because it reviewed nomination applications and vetted potential candidates to ensure they met the legal requirements for running in parliamentary elections. ${ }^{71}$ Article 16 of Law No. 73 required that an Interior Ministry appointee manage the Technical Secretariat. ${ }^{72}$ The appointment of a political figure as head of the Technical Secretariat gave the ruling NDP party considerable influence in selecting its political

62. See id.

63. Democracy Reporting Int'l, The Arab Republic of Egypt, supra note 58, at 26-27 (noting that the structure gave the NDP overriding control and led opposition figures to question the independence and impartiality of the HEC).

64. Tamir Moustafa, The Struggle for Constitutional Power: Law, Politics, and EConomic Development in Egypt 191 (2007).

65. Id. at 192-93. Meanwhile state security blockaded entire streets to prevent voters from reaching the polls. Id. at 197.

66. Moustafa, supra note 50, at 921 .

67. Moustafa, supra note 64, at 193.

68. Id. at 194 .

69. Chazli \& Chazli, supra note 19, at 26.

70. Law No. 73 of 1956 (Concerning the Exercise of Political Rights), Al-Jarida AlRasmiyya, art. 3(bis) (a) (Egypt).

71. Structure and Responsibilities of the Higher Elections Commission, supra note 23 , at 16 .

72. Id. at 6 . 
opponents for a given election and deterred it from objectively investigating voting irregularities. Opposition parties, civil society leaders, and political activists cited this undue influence as evidence of the HEC's lack of independence. ${ }^{73}$

Under the pre-revolution version of Law No. 73 of 1956, the Egyptian president had sole authority to appoint members of the Technical Secretariat. ${ }^{74}$ Consequently, the HEC was politicized and favored members of Mubarak's NDP in parliamentary elections. ${ }^{75}$ Before the revolution, the HEC's politicization allowed the ruling NDP to staff the supervisory body with pro-NDP partisans, limiting the potential avenues for opposition parties to seek redress for demonstrated vote rigging, fraud, and voter intimidation. ${ }^{76}$ Moreover, the HEC's structure enabled the NDP to craft the rules and electoral parameters of the elections by granting the NDP de facto control of the HEC's power to promulgate electoral rules and guidelines. ${ }^{77}$ Without independent oversight, elections were subjected to improper interference by the dominant NDP at the expense of other candidates. This dubious history led to demands for post-revolution reform of the HEC membership selection process.

\section{B. Post-Revolution Amendments to Political Rights and the High Elections Commission-Law No. 73 of 1956}

The abrogation of the 1971 Constitution on February 13, 2011, created a constitutional vacuum in Egypt, ${ }^{78}$ depriving elections of constitutional legitimacy. A committee of jurists appointed by the SCAF proposed a referendum to amend Article 88, which governs the rules and procedures for parliamentary elections and candi-

73. Gamal Essam El-Din, Desperately Seeking the HEC, Al-Ahram Weekly (Sept. 30, 2010), http://weekly.ahram.org.eg/2010/1017/eg6.htm.

74. $I d$.

75. See id.

76. Int'l Found. for Electoral Sys., Elections in Egypt: Analysis of the 2011 Parllamentary Electoral System 3 (2011) [hereinafter Analysis of the 2011 Parliamentary Electoral System].

77. Democracy Reporting Int'l, The Arab Republic of Egypt, supra note 58, at 27.

78. Mariam Fam, Maram Mazen \& Ahmed Namatalla, Egypt Constitution Suspended, Parliament Dissolved, Military Council Says, Bloomberc (Feb. 14, 2011), http://www.bloomberg. $\mathrm{com} /$ news/2011-02-14/egyptian-military-says-protests-harming-the-economy-may-threatensecurity.html (explaining that the army suspended the constitution and would be meeting demands made by the opposition movement that forced Mubarak from office, and additionally would rule Egypt until elections are held); see also Kochan, supra note 33, at 902 (asserting that power vacuums often follow nonviolent revolutions because the revolution creates a void). 
date selection monitoring. ${ }^{79}$ Under the amended articles, an alljudge HEC would administer and supervise elections and results announcements. ${ }^{80}$ The referendum culminated after a fervent public debate about whether elections should occur before drafting a new constitution. ${ }^{81}$

Advocates of a "no" vote wanted to draft a new constitution instead of amending what they perceived as a highly flawed 1971 Constitution. ${ }^{82}$ The "no" voters sought to postpone parliamentary and presidential elections until a new constitution was drafted via a public and transparent process that incorporated the desires of Egyptians seeking structural reforms. ${ }^{83}$ The "yes" voters wanted to merely amend the 1971 Constitution to remove the NDP's grip on power in order to give new political parties an opportunity to win elections. ${ }^{84}$ The "yes" voters were willing to hold off drafting a new constitution until a new parliament and president were elected. ${ }^{85}$ They believed this order of events would provide a more stable transition from authoritarianism to democracy. ${ }^{86}$ With a record high $41 \%$ voter turnout in the referendum, $77 \%$ of voters approved the amendment of the 1971 Constitution and postponement of drafting a new constitution until after the parliamentary

79. See Constitution of the Arab Republic of Egypt art. 88, Sept. 11, 1971, as amended, May 22, 1980, May 25, 2005, Mar. 26, 2007 ("The Law shall determine the conditions which members of the Assembly must fulfill as well as the rules of election and referendum, while the ballot shall be conducted under the supervision of the members of a judiciary organ.").

80. See Noha El-Hennawy, Commission Announces Proposed Changes to Egyptian Constitution, EGYPT INDEP. (Feb. 26, 2011), http://www.egyptindependent.com/news/commissionannounces-proposed-changes-egyptian-constitution.

81. Egypt Referendum Strongly Backs Constitution Changes, BBC (Mar. 20, 2011), http:// www.bbc.co.uk/news/world-middle-east-12801125; Mallat et al., supra note 1, at 190-92 (including a lengthy discussion of all the choices debated regarding when to hold elections and when to draft a new constitution).

82. Yasmine El Rashidi, Egypt's First Vote, N.Y. Rev. Books (Mar. 24, 2011), http:// www.nybooks.com/blogs/nyrblog/2011/mar/24/egypts-first-vote/; Mallat et al., supra note 1 , at 190 (advocating complete redrafting of constitution before parliamentary elections).

83. Rashidi, supra note 82; Mallat et al., supra note 1, at 191.

84. Demands to disqualify NDP candidates from parliamentary elections continued into the winter of 2011. See, e.g., Tamer Mohamed, HEC Urged to Ban All Egypt NDP Affiliates, Egrptian GazeTTe (Nov. 13, 2011) http://213.158.162.45/ egyptian/index.php? action=news\&id=22213\&title=HECurgedtobarallEgyptNDPaffiliates (noting demands by The Free Front for Peaceful Change, a political group formed after the revolution).

85. Mallat et al., supra note 1, at 191 (emphasizing the minimization of time the military was in control).

86. Id. at $191-92$. 
elections. ${ }^{87}$ Twenty-three percent of voters opposed amending the abrogated 1971 Constitution. ${ }^{88}$

In the March 2011 constitutional referendum, Egyptians voted to amend Article 88, in addition to other articles, of the abrogated 1971 Constitution. ${ }^{89}$ The referendum reinstituted judicial supervision of elections, which was abolished in $2007,{ }^{90}$ by amending the following provision of Article 88, ${ }^{91}$ declaring in pertinent part:

A higher commission with full judicial composition shall supervise elections and referenda and voter registration until the declaration of the result, all of which shall be in accordance with the regulations of the law. Balloting and counting shall be undertaken under the supervision of members of judicial bodies nominated by the supreme councils thereof whose selection shall be decreed by the higher committee. ${ }^{92}$

Pursuant to this new constitutional provision, the SCAF issued Decrees No. 46 and No. 110 of 2011 to amend thirty-two articles of Law No. 73 of 1956, most of which concern the structure, membership, and responsibilities of the HEC. ${ }^{93}$ Parliamentary appointments to the HEC are now prohibited. ${ }^{94}$ Instead, the HEC is composed solely of senior judges, ${ }^{95}$ including: (1) the president of the Cairo Court of Appeals as chair; (2) the two most senior depu-

87. Int'l Found. for Electoral Sys., Elections in Egypt: Lessons from the 2011 Constitutional Referendum and Constitutional Declaration 4 (2011), available at http://www.ifes.org/Content/Publications/White-Papers/2011/ /media/Files/Publications/White\%20PaperReport/2011/2011_egypt_briefing_paper_II.pdf.

88. Alex Kireev, Egypt. Constitutional Referendum 2011, Electoral Geography, http:// www.electoralgeography.com/new/en/countries/e/egypt/egypt-constitutional-referendum-2011.html (last visited Jan. 8, 2013). As of the writing of this Article, Egypt has yet to draft a new constitution.

89. The public referendum also concerned amendments to articles $75,76,77,93$, 139, and 149 and cancellation of 179. Gregg Carlstrom, Egypt's Proposed Constitutional Amendments, Al JAzEerA (Mar. 15, 2011), http://www.aljazeera.com/indepth/spotlight/ anger-in-egypt/2011/03/20113156309594476.html.

90. Gregg Carlstrom, Explainer: Inside Egypt's Recent Elections, AL Jazeera (Nov. 15, 2011), http://www.aljazeera.com/indepth/spotlight/egypt/2011/11/2011111388371569 49.html.

91. Fact Sheet: Amendments to the Law on the Exercise of Political Rights, Egypt STATE INFo. SERV., http://www.sis.gov.eg/En/LastPage.aspx?Category_ID=1169 (last visited Jan. 8, 2013) (explaining the principal reforms include direct judicial composition and supervision).

92. Constitution of the Arab Republic of Egypt art. 88, 11 Sept. 1971, as amended, May 22, 1980, May 25, 2005, Mar. 26, 2007, Mar. 30, 2011 (English translation) (emphasis added).

93. Analysis of the 2011 Parliamentary Electoral System, supra note 76, at 4.

94. Structure and Responsibilities of the Higher Elections Commission, supra note 23 , at 2 .

95. Id. at 3 (construing Constitution of the Arab Republic of Egypt arts. 166, 168, 11 Sept. 1971, as amended, May 22, 1980, May 25, 2005, Mar. 26, 2007). 
ties of the president of the Court of Cassation; (3) the two most senior deputies of the president of the State Council; and (4) the two most senior presidents of the Court of Appeals after the president of the Cairo Court of Appeals. ${ }^{96}$ The Supreme Councils of the courts from which the HEC chair and members are drawn select a reserve member for each position based on seniority. ${ }^{97}$ Moreover, HEC members cannot serve on other bodies that supervise elections or referenda. ${ }^{98}$

Although the amendments were well-received by Egyptians seeking to strengthen the independence of the HEC, the HEC is not as independent as it appears. Egypt's president appoints the senior judges in the highest courts thereby granting him indirect control over the judicial elections commissions. ${ }^{99}$ The president also influences senior judges through lucrative placements in Egyptian state agencies and coveted consulting assignments abroad. ${ }^{100}$ Similarly, appointments to the election commissions are remunerated with a sizeable bonus, further compromising the independence of the judge who seeks to retain his appointment. ${ }^{101}$ Indeed, some senior judges adjudicating cases where the state was a party were criticized for perceived leniency in favor of the executive branch. ${ }^{102}$ Hence, an Egyptian judge interested in such opportunities is unlikely to cross the executive branch in cases involving high profile political disputes. ${ }^{103}$ As discussed below in more detail in Part IV(C), a judi-

96. Id. at 12 .

97. Id. at 3 .

98. Id.

99. Chazli \& Chazli, supra note 19, at 30. The executive branch has power to appoint the president of the SCC, president of the Court of Cassation, president of the State Council, Public Prosecutor, High Court presidents, and deputies at the Ministry of Justice. $I d$. at 29.

100. Id. at 32-33. These temporary appointments of judges to governments abroad or international organizations are known as "secondments." Id. They involve attractive compensation packages as well as opportunities to live abroad in more developed countries. See also Moustafa, supra note 64, at 79 (highlighting the lucrative legal consulting positions distributed to judges with critical positions in exchange for tacit compliance with government interests in sensitive cases); Abdullah Khalil et al., Cairo Inst. For Human Rights Studies, Towards Establishing a Vision for the Independence and Impartiality of the EGYPTIAN JUDiCIARY 15 (2011) (recommending transferring the authority to transfer, assign, or detail judges from the president to the High Judicial Council).

101. Moustafa, supra note 64, at 193.

102. Id. at 193-94; see also Egyptian Policeman Jailed over Activist Death, AL Jazeera (Oct. 26, 2011), http://www.aljazeera.com/news/middleeast/2011/10/2011102614381282471. html.

103. This was certainly the case in the 2000 and 2005 parliamentary elections. See MoustaFA, supra note 64, at 193 (highlighting that judicial personnel participating in election monitoring in the 2000 elections received a large bonus, causing reformers to suspect 
cially composed elections commission also entails risks to both the electoral process and the independence of the judiciary.

\section{Limited Reforms to the HEC's Membership}

The permanent HEC Technical Secretariat, whose members were previously appointed by the president of the republic, was abolished by the post-revolution amendments. ${ }^{104}$ In its place, the HEC chair creates a permanent General Secretariat headed by one of the deputies of the president of the Court of Cassation. ${ }^{105}$ In contrast to the pre-revolution model, the HEC-instead of the president-now determines the composition and responsibilities of the General Secretariat. ${ }^{106}$ The HEC delineates the Secretariat's objectives and governing regulations. ${ }^{107}$ Members of the General Secretariat consist of an unspecified number of judges selected by the High Judicial Council, in addition to representatives of the Ministers of Interior, Communications and Information Technology, and Local Development. ${ }^{108}$ Notwithstanding the removal of direct presidential control over the HEC, it remains to be seen whether the appointed representatives of the executive agencies will unduly politicize the HEC in favor of their respective political parties.

The HEC membership selection process begins with the presidents of the Court of Cassation, State Council, and Court of Appeals nominating their two most senior deputies to the Minister of Justice. ${ }^{109}$ The Minister then recommends these individuals to the president of the republic, who issues a decree naming them as HEC members. ${ }^{110}$ This new structure anticipates deference by the Minister of Justice and the president to the nominating judges' selection of HEC members. Because approval by the Minister of Justice and president is a mere formality, the new process transfers control of the HEC from the executive branch to the judicial branch, thereby depoliticizing oversight of parliamentary elections.

the bonus was used to assure cooperation with the Ministry of Interior and the Ministry of Justice).

104. Structure and Responsibilities of the Higher Elections Commission, supra note 23 , at 23 .

105. Law No. 73 of 1956 (Concerning the Exercise of Political Rights), Al-Jarida AlRasmiyya, art. 3(bis) (a) (Egypt).

106. Id.

107. Id.

108. Strlcture and Responsibilities of the Higher Elections Commission, supra note 23 , at 3 .

109. Id.

110. Id. 
Consistent with its responsibility to supervise parliamentary elections and national referenda, the HEC forms a committee in each governorate to regulate elections, ${ }^{111}$ implement elections monitoring, and receive reports and grievances relating to the electoral process. ${ }^{112}$ Each committee, chaired by the president of the Courts of Appeals, includes (1) a State Council justice; ${ }^{113}$ (2) the president of the Court of First Instance; ${ }^{114}$ (3) a deputy president of the Administrative Lawsuits Authority; ${ }^{115}$ and (4) a deputy president of the Administrative Prosecution. ${ }^{116}$ These significant changes to the composition of the HEC further contribute to the depoliticization of the election process by shifting election oversight from the executive branch to the judicial branch. ${ }^{117}$ However, as previously noted, the current executive appointment of senior judges coupled with the hierarchical structure of the judiciary still grants the executive branch significant control over the elections commissions, albeit indirectly.

So long as the Egyptian judiciary maintains its independence, ${ }^{118}$ which is arguably at risk if the executive branch can unilaterally

111. Law No. 73 of 1956 (Concerning the Exercise of Political Rights), Al-jarida AlRasmiyya, arts. 23-26 (Egypt).

112. Id. art. 3 (bis) (e), (f).

113. Also known as the Administrative Courts, the State Council presides over any administrative disputes in which any administrative body is a party. Wahab, supra note 8 , $\S 6.10$. The State Council has its own judicial structure and hierarchy, where the Supreme Administrative Court sits at the apex of that structure. Id.

114. The Courts of First Instance are the trial courts in Egypt. Id. $\$$ 6. The Courts' jurisdiction includes presiding over civil suits brought before them by private parties. Id. $\S 7$.

115. The Egyptian State Lawsuits Authority is an Egyptian judicial institution that was established in 1874, nine years before the Egyptian national courts were established in 1883. Id. $\$ 6.8$. Despite being recognized as a judicial institution, the Authority does not perform any actual judicial function. Id. Instead, the Authority's role is confined to representing the State before national and international courts and arbitral tribunals. Id. It has the legal authority to plead on behalf of the State. Id.

116. Structure and Responsibilities of the Higher Elections Commission, supra note 23 , at 4 .

117. Mallat et al., supra note 1 , at 187.

118. Dina Zayed, Analysis: Egypt's Judges Shoulder Hopes for Democracy, Reuters (Nov. 2, 2011), http://www.reuters.com/article/2011/11/02/us-egypt-judiciary-idUSTRE7A13XR2 0111102. Zayed described the Egyptian judiciary as follows:

One of the first Arab states to establish a judiciary, Egypt has a legacy of judicial independence that endured even after a 1952 coup ushered in successive military rulers. For decades, the Supreme Constitutional Court (SCC) and other courts provided avenues for opposition parties, rights groups and activists to meaningfully challenge authorities.

Id. For an in-depth analysis of Egypt's judicial system, see generally Nathan J. Brown, The Rule of Law in the Arab World: Courts in Egypt and the Gulf (1997). See also MousTAFA, supra note 64, at 91-104 (summarizing the SCC's refusal to succumb to co-optation by the executive branch). 
appoint senior judges to the highest courts, ${ }^{119}$ these reforms are an improvement. That said, the judiciary's direct supervision of elections and arbitration of election disputes in the first instance exposes it to undue politicization. Political parties will inevitably challenge unfavorable HEC and PEC rulings on political disputes and directly challenge the legitimacy of the judiciary. Indeed, this occurred in April 2012 when the judges on the PEC disqualified ten presidential candidates. ${ }^{120}$ Opponents of the ruling questioned the legitimacy of the PEC. ${ }^{121}$ Placing judges in the direct line of fire in political disputes ultimately compromises the judiciary's independence, leading to much larger governance problems. Additionally, the executive branch may pressure judges, as it did prior to 2007 when the political-appointee-run elections commission was created, to legitimize sham election results. ${ }^{122}$ Therefore, the HEC and PEC should be transformed into independent (nonjudicial) elections commissions whose decisions are subject to judicial review, thereby preserving the legitimacy and independence of the judiciary.

\section{Expansion of the HEC's Mandate}

In addition to changing the composition of the HEC, SCAF Decrees 46 and 110 of 2011 expand the HEC's scope of authority. ${ }^{123}$ Before the January 25 Revolution, the HEC's mandate was limited to recommending rules for election regulation and guidelines for the electoral process. ${ }^{124}$ Critics often highlighted that the pre-revolution HEC had little authority to resolve election irregularities. ${ }^{125}$ For example, a ruling in 2010 by the Supreme Administrative Court, Egypt's highest court for settling disputes between

119. To offset the staunchly independent members of the judiciary, Mubarak appointed a number of judges loyal to the NDP and President Mubarak. Nathan Brown, Egypt's Judges in a Revolutionary Age, Carnegie Endowment for InT'L Peace (Feb. 2012), http://egyptelections.carnegieendowment.org/2012/02/22/egypt\%E2\%80\%99s-judgesin-a-revolutionary-age.

120. Rana Khazbak, Election Commission's Disqualifications Dubious, Say Experts, EcyPT INDEP. (Apr. 18, 2012), http://www.egyptindependent.com/news/elections-commissionsdisqualifications-dubious-say-experts.

121. Id.

122. Brown, supra note 119.

123. Decree Law No. 46 (Concerning Amendments to Law No. 73 of 1956) (Egypt); Decree Law No. 1110 (Concerning Amendments to Law No. 73 of 1956) (Egypt).

124. Structure and Responsibilities of the Higher Elections Commission, supra note 23 , at $4-5$.

125. Democracy Reporting Int'l, The Arab Republic of Egypt, supra note 58, at 27. 
citizens and state bodies, ${ }^{126}$ invalidated parliamentary election results following widespread voting fraud and voter intimidation. ${ }^{127}$ In its ruling, the Supreme Administrative Court held that the HEC failed to safeguard election sites and investigate voting irregularities. ${ }^{128}$ Furthermore, the Supreme Administrative Court held that the HEC's selection of judges to supervise more than 200 general polling stations violated the Judicial Authority Law, ${ }^{129}$ which granted the authority to the General Assembly of the Courts. ${ }^{130}$ In invalidating the election results, the Court strongly condemned the HEC's lack of independence from the Interior Ministry and the HEC's systematic disregard for the law, the constitution, and previous court rulings. ${ }^{131}$ Such outcomes were inevitable given that the HEC's politicized membership was composed of NDP operatives tasked with ensuring the NDP retained its dominance in both houses of parliament. ${ }^{132}$

Post-revolution, the HEC was granted new powers to investigate complaints of electoral irregularities. Declaration No. 120 of 2011 amended articles $40,43,45,46,47,48,49$, and 50 of the Law on the Exercise of Political Rights to impose punitive measures for engaging in violence, bribery, and religious sloganeering in elections. ${ }^{133}$ The HEC is also responsible for ensuring a level playing field among political parties to avoid repeating past favoritism towards the majority party. ${ }^{134}$ Notably, the HEC is now responsible for managing Egyptian and international election observers ${ }^{135}-\mathrm{a}$ positive indication that Egypt recognizes that independent observers facilitate free and fair elections. The HEC, however, limited

126. The Supreme Administrative Court has jurisdiction over appeals in administrative disputes in which any administrative body is a party in a matter. Wahab, supra note 8 , $\$ 6.10$. Administrative courts have jurisdiction over the settlement of administrative or public law matters governed by the jus imperii. Id. $\$ 7$.

127. Elections Held in 2010, Inter-Parliamentary Union, http://www.ipu.org/parlinee/reports/arc/2097_10.htm (last visited Jan. 8, 2013).

128. See id.

129. Law No. 142 of 2006 (Concerning the Judicial Authority).

130. Democracy Reporting Int'L, The Arab Republic of Egrpt, supra note 58, at 27.

131. See Elections Held in 2010, supra note 127.

132. See supra Part III.A.

133. M. Cherif Bassiouni, Egyptian Am. Rule of Law Ass'n, Chronicles of the Egyptian Revolution of 25 January 2011: Legislative and Presidential Elections 17, 24-28 (2012), available at http://www.earla.org/userfiles/Egypt\%20Update\%20\%20Thirteenth $\% 20(13 \% 20-\% 20$ Cherif\%20Bassiouni).pdf.

134. Democracy Reporting Int'l, The Road to Elections in Egypt: Electoral. REFORMS SinCE FEBruary 2011, at 3 (2011) (stating that legislative amendments requiring judges compose the HEC will improve public confidence in the electoral process because of historical public trust in the independence of the judiciary).

135. Id. at 3-4. 
the role of international monitors and media to participating in "following" the elections as opposed to "observing" the elections, ${ }^{136}$ invoking Egypt's sovereignty to justify their decision. ${ }^{137}$

Additional new post-revolution powers include the ability to: (1) appoint members and secretaries of the general election, polling, and counting committees; (2) supervise the preparation, content, method of review, editing and updating, registration, and correction of voter lists from the National ID database; (3) promulgate rules for regulating electoral campaigning, including "equal-time" rules for TV and radio advertising; (4) develop a system of electoral symbols for political parties and independent candidates; and (5) declare the results of elections and referenda and determine the time for run-off elections. ${ }^{138}$ Whether the HEC effectively enforces its broader mandate is yet to be determined and is beyond the scope of this Article. ${ }^{139}$

However, the HEC also lost powers. The HEC can no longer: (1) propose constituency-defining rules; (2) contribute to raising awareness of elections and developing rules to guide that process; or (3) monitor adherence to an election code of ethics. ${ }^{140}$ Political analysts predict these changes will impair the political process because no other governmental entity is tasked with educating voters about the electoral process. ${ }^{141}$ These changes, coupled with voter fatigue arising from the complicated voting process, are likely to adversely impact voter turnout in future elections. ${ }^{142}$

Meanwhile, many ambiguities in the electoral laws remain unresolved. For instance, while the amended version of Law No. 38 of 1972 envisions the formation of political coalitions, it does not provide any details on how coalitions may register. ${ }^{143}$ Without a clear and accessible coalition-forming process, smaller parties are disadvantaged because they rely on coalitions to pool their

136. Bassiouni, supra note 133 , at 18 .

137. Id.

138. Structure and Responsibilities of the Higher Elections Commission, supra note 23 , at 13 .

139. But see Ernesto Londono \& Ingy Hassieb, Allegations of Fraud Cloud Egypt Runoff, $\mathrm{W}_{\mathrm{ASH}}$ Post, May 27, 2012, at A17 (documenting allegations of violation of election finance laws by Shafiq).

140. Structure and Responsibilities of the Higher Elections Commission, supra note 23 , at 5 .

141. Democracy Reporting Int'l, Egypt's Elections: Greater Transparency to Strengthen Confidence 2 (2011) [hereinafter Democracy Reporting Int'l, Greater TRANSPARENCY].

142. Id.

143. Law No. 38 of 1972 (Concerning the People's Assembly), Al-Jarida Al-Rasmiyya, 28 Sept. 1972 (Egypt). 
resources to compete against the larger parties for seats in the parliament. ${ }^{144}$ Law No. 38 of 1972 also fails to specify how to distribute votes garnered by a coalition among its various political parties. ${ }^{145}$ These details are necessary to determine which specific parties meet the minimum number of votes needed for a parliamentary seat. Without clear rules governing coalitions, political disputes among coalition members seeking a seat in the parliament are inevitable. As a result, Law No. 38 deters formations of coalitions, thus disfavoring smaller parties. ${ }^{146}$

Despite the shortcomings of post-revolution amendments to Law No. 73 of 1956, they signify a positive development towards democracy. By removing control over election monitoring from the executive branch and placing it squarely under the purview of the judiciary, the post-revolution amendments shift Egypt's electoral framework towards a more transparent and independent processso long as the judiciary is independent. ${ }^{147}$ The HEC's expanded authority increases the likelihood that election irregularities will be adequately and promptly redressed. While it is too soon to conclude whether these reforms are sufficient to establish a sustainable democracy in Egypt, they are certainly a positive step in the right direction.

\section{The People's Assembly before the Revolution-Law No. 38 of 1972}

The overthrow of the British-backed monarchy in 1952 by Egyptian military officers ushered in a series of political reforms that came to be known as "pan-Arab socialism." ${ }^{48}$ Introduced by President Gamal Abdel-Nasser, pan-Arab socialism sought to politically enfranchise peasants and rural farmers-two lower classes long

144. See Decree Law No. 108 of 2011 (Concerning Amendments to Law No. 38), art. XV (Egypt).

145. See id.

146. A Look at the Major Alliances for Egypt's Parliamentary Elections, VoICE AM. (Nov. 27, 2011), http://blogs.voanews.com/breaking-news/2011/11/27/a-look-at-major-alliancesfor-egypts-parliamentary-elections. In the 2011-2012 parliamentary elections, political parties formed four major coalitions: (1) The Democratic Alliance for Egypt; (2) Islamist Alliance; (3) Egyptian Bloc; (4) Completing the Revolution Alliance. BAssiouni, supra note 133 , at $24-28$.

147. See Mallat et al., supra note 1 , at 187 (identifying the judiciary as the only group with the necessary expertise and detachment from executive and legislative positions to supervise); Brown, supra note 119 (noting that Sadat and Mubarak undid Nasser's policies that compromised judicial independence by granting leading judicial bodies-the administrative court systems, for instance, as well as the regular court system-considerable autonomy in their own affairs).

148. See Takeshi Hayashi, The Developing Economies 88 (1964). 
neglected under the monarchy. ${ }^{149}$ Following the dissolution of Egypt's political union with Syria in 1961, a new provisional constitution was created in 1964, establishing an elected 350-member unicameral parliament known as the National Assembly. ${ }^{150}$ To enfranchise peasants and farmers, the provisional 1964 Constitution required that "workers" and "farmers" make up at least onehalf of the National Assembly and delegated to the president the power to appoint ten members. ${ }^{151}$ Both practices were incorporated into the permanent 1971 Constitution and the election process for the People's Assembly-the successor to the National Assembly. ${ }^{152}$

Law No. 38 of 1972 established a 454-member People's Assembly. ${ }^{153}$ It allocated ten seats for presidential appointment with the remaining 444 members elected through a two-round system. ${ }^{154}$ The 444 elected members consisted of two candidates elected from each of Egypt's 222 electoral districts by a simple majority vote. ${ }^{155}$ Additionally, pursuant to Article 87, at least one winning candidate in each district had to be a "worker" or a "farmer."156 Thus, Law No. 38 of 1972 required that ballots identify candidates as

149. Id.

150. Moustafa, supra note 50 , at 889 .

151. See id.

152. Brown \& Stilt, supra note 28 , at 3.

153. Law No. 38 of 1972 (Concerning the People's Assembly), Al-Jarida Al-Rasmiyya, 28 Sept. 1972 (Egypt).

154. Id. art. 2. Law No. 38 of 1972 does not explicitly define "professionals." See id. This term, however, likely refers to individuals working in an occupation with a professional syndicate. See Donald M. Reid, The Rise of Professions and Professional Organizations in Modern Egypt, 16 Comp. Stud. Soc'y \& Hist. 24, 24, 28, 48 (1974) (noting occupations with a professional syndicate include doctors, lawyers, engineers, pharmacists, teachers, and journalists).

155. Law No. 206 of 1990 (Concerning Political Constituencies of the People's Assembly and Shura Council), Al-Jarida Al-Rasmiyya (Egypt). For a detailed discussion of the history of Egypt's elections and attempts to adopt the proportional representation system, see Moustafa, supra note 64, at 96-103.

156. Article 2 of Law No. 38 of 1972 defines "farmer" as a "person whose sole work and main source of living is cultivation, and resides in the countryside, providing he, his wife and minor children shall not own or lease more than ten feddans [acres]." Law No. 38 of 1972 (Concerning the People's Assembly), AlJarida Al-Rasmiyya, 28 Sept. 1972, art. 2 (Egypt). Moreover, it defines "worker" as a "person who depends mainly on his income from manual or mental work in agriculture, industry or services ... [who is] not . . a member of a professional syndicate, or recorded in the commercial register, or a holder of a high academic qualification." Id. 
"worker/farmer" 157 or "professional." 158 Under this system, a candidate won a seat by obtaining a simple majority of all valid votes cast in the two-member district in the first round. ${ }^{159}$ The occupational requirements under Article 87 of the 1971 Constitution, however, significantly complicated the means for casting votes and the process of determining the winning candidates. ${ }^{160}$

The following hypotheticals illustrate the byzantine nature of the system: (1) if only one candidate obtained a simple majority, and he or she was a professional, then the top two worker/farmer candidates competed in a second round; (2) if only one candidate obtained a simple majority, and he or she was a worker/farmer, then the next two candidates with the highest number of votes (regardless of category) competed in the second round; (3) if two candidates were elected in the first round and both were professionals, then only the candidate with the highest vote total was elected, and the top two worker/farmer candidates competed in a second round; and (4) if no candidate obtained a simple majority, a second round would be held consisting of four candidates, with two worker/farmer candidates. At least one seat had to be awarded to the top worker/farmer candidate. ${ }^{161}$ Predictably, these convoluted rules created a fertile environment for election fraud where candidates mischaracterized themselves as farmers or workers to increase their chances of securing a parliamentary seat. ${ }^{162}$

Through the 1980s, Egypt used a proportional representation system for both national and local elections. ${ }^{163}$ Only members of officially recognized political parties could participate in elections

157. Law No. 38 of 1972 requires "workers" to submit a certificate from the employer, certified by the Office of Social Insurance, listing the candidate's benefit of employment, remuneration, and qualifications; a certificate from the union to which they belong; and proof that he/she began working there before they acquired a university degree. See id. The certificate must also indicate whether the employee is still registered in the particular union. Id.

158. Law No. 38 of 1972 requires "farmers" to submit official documentation for the acquisition of agricultural land held by the candidate, his wife, and minor children, whatever the type of property owned or rented, with a maximum of ten feddans (acres). Id. Farmers must also submit a certificate stating that agriculture is the main source of livelihood and that he/she resides in the village or rural area. Id.

159. Analysis of The 2011 Parliamentary Electoral System, supra note 76 , at 3.

160. See id. at 3, 9 (explaining the process and consequences of the occupational requirements); see also Kochan, supra note 33, at 908 (noting that post-revolution elections take time).

161. See Analysis of the 2011 Parliamentary Electoral System, supra note 76, at 3.

162. Jano Charbel, Eye on Elections: Does the Workers and Farmers Quota Help Workers and Farmers?, EGYPT INDEP. (Nov. 27, 2011), http://www.egyptindependent.com/node/520876.

163. Moustafa, supra note 64 , at 96. 
through party lists. ${ }^{164}$ Parties had to obtain at least $8 \%$ of the votes cast nationally to win a parliamentary seat-a high threshold that most opposition parties could not meet. ${ }^{165}$ When parties fell short of this threshold, their votes were transferred to the party that won a plurality of the seats. ${ }^{166}$ Law No. 40 of 1977 granted the Political Parties Affairs Committee the authority to adjudicate a political party's application for official party recognition. ${ }^{167}$ The NDP, as ruling party, manipulated this process by appointing pro-NDP members to the Committee, which in turn recognized political parties that posed little threat to the NDP's grip on power. ${ }^{168}$ Altogether, these factors enabled the NDP to thwart serious political challengers. ${ }^{169}$

In 1987, the SCC struck down the proportional representation list system as unconstitutional. ${ }^{170}$ The Court held that the system infringed on citizens' constitutional right to participate in public life because it denied them the opportunity to run for office unless they joined an official political party. ${ }^{171}$ Following the Court's ruling, the People's Assembly dissolved, new electoral laws were drafted, and new elections were held in 1987.172

The 1987 amendments to Law No. 38 of 1972 minimally complied with the SCC's ruling. ${ }^{173}$ The amendments divided the country into twenty-four multiple-member districts for proportional distribution among party lists and reserved two seats per district for independent candidates. ${ }^{174}$ The amendments, however, maintained the $8 \%$ minimum threshold that was required for gaining a parliamentary seat and gerrymandered electoral districts in a manner that significantly disadvantaged opposition parties. ${ }^{175}$ For

164. Id.

165. Id. Notably, post-revolution amendments decreased this threshold to $5 \%$ of the votes cast nationally, making it easier for minority parties to field candidates. See id. at 210-11.

166. Id. at 96 .

167. Law No. 40 of 1977 (Concerning the Political Parties System), Al-Jarida Al-Rasmiyya art. 8 (Egypt).

168. See Moustafa, supra note 64 , at 94 .

169. See id. at 93-97 (noting how the populace felt there was a lack of competition in the political process).

170. Id. at 97.

171. Id.

172. Id.

173. Id.

174. Id. at 97-98.

175. Id. at 98 . Egypt has a history of gerrymandering by the dominant party to weaken opposition candidates. Id. at 190 (describing the blatant gerrymandering that occurred in the lead up to the 1999 presidential elections and 2000 parliamentary elections). 
example, the amendments allocated thirteen People's Assembly seats to a district with five million residents while allocating sixteen seats to another district with only two million residents. ${ }^{176}$ Other districts with as few as 350,000 residents received as many as five seats. ${ }^{177}$

The SCC struck down these amendments in 1990.178 As a result, Egypt abandoned the proportional representation system altogether and adopted a winner-take-all system for elections to the People's Assembly. ${ }^{179}$ Each of the country's 222 districts was allocated two seats. ${ }^{180}$ Farmers and workers had to win at least one seat per district, as required under Article 87 of the 1971 Constitution. ${ }^{181}$ Opposition parties initially welcomed these changes and pushed for further electoral reforms. ${ }^{182}$ Instead, the Mubarak regime issued Law No. 206 of 1990 that gerrymandered district boundaries to the advantage of the then-ruling NDP. ${ }^{183}$

In November 2010, the Mubarak regime amended Law No. 38 of 1972 to increase the number of seats in the People's Assembly to 518 in order to accommodate a new sixty-four-seat quota for female candidates. ${ }^{184}$ Six months prior, in February 2010, the UN criticized Egypt for its dismally low female representation in government. ${ }^{185}$ As discussed in more detail below in Part IV(A)(1), the Mubarak regime consequently adopted and touted a gender quota as a mechanism for politically empowering women. ${ }^{186}$ In practice, however, the quota was merely an additional means by which to install more Mubarak loyalists (albeit women) into the parliament. ${ }^{187}$ Under the 2010 amendments, the Egyptian president retained the right to appoint ten seats with the remaining 508 seats elected through the two-member district system discussed

\footnotetext{
176. Id.

177. Id.

178. Id. at 99 .

179. Id. at 100 .

180. Id.

181. Id.

182. Id.

183. Id.

184. Adam Morrow, Egypt: Disputes Rise over Quotas for Women MPs, InTER Press Serv. (July 27, 2009), http://www.ipsnews.net/2009/07/egypt-disputes-rise-over-quotas-forwomen-mps.

185. Concluding Observations, supra note 39

186. See infra Part IV.A.

187. Amnesty Int'l, Women Demand Equality in Shaping New Egypt 7 (2011) (noting that all of the seats reserved for women under the quota system went to members of the ruling NDP party).
} 
above. ${ }^{188}$ Although not required by law, President Mubarak traditionally reserved seven of the ten presidentially appointed seats for Coptics. ${ }^{189}$ In the end, Egyptians viewed the 2010 parliamentary elections as the most fraudulent under Mubarak's rule, which ultimately led to his demise. ${ }^{190}$

D. Changes to the People's Assembly after the Revolution-Law No. 38 of 1972

On September 25, 2011, the SCAF issued Decree No. 108 of 2011, which amended Law No. 38 of 1972 to reduce the People's Assembly from 518 to 508 seats. ${ }^{191}$ The amendments authorize the SCAF to appoint up to ten seats; and of the remaining 498 seats, two-thirds (332 seats) are elected through proportional party representation and one-third (166 seats) through an independent candidate system. ${ }^{192}$ To the detriment of female representation, Decree No. 108 abolishes the pre-revolution 64-seat quota for female candidates. ${ }^{193}$ The following Sections highlight Decree No. 108 's failure to promote female and minority representation in Egypt's parliament and the continuation of the worker/farmer quota, which increases the risk of election fraud.

As discussed in further detail below, ${ }^{194}$ five months after Egypt's first post-revolution 2011 parliamentary elections, the SCC struck down portions of the election law as unconstitutional and ordered a dissolution of the People's Assembly. ${ }^{195}$ This has only exacerbated political uncertainties and further deepened the divide between the Muslim Brotherhood, who dominated the People's Assembly, and the SCAF.

188. Elections Held in 2010, supra note 127.

189. See Analysis of the 2011 Parliamentary Electoral System, supra note 76, at 1. In the 2011 People's Assembly elections, the SCAF followed this precedent by appointing five Coptics. Results of Egypt's People's Assembly Election, Carnegre ENDOWment for INT'L PeAcE (Jan. 25，2012), http://egyptelections.carnegieendowment.org/2012/01/25/ results-of-egypt $\% \mathrm{E} 2 \% 80 \% 99$ s-people $\% \mathrm{E} 2 \% 80 \% 99$ s-assembly-elections.

190. Bassiouni, supra note 133 , at 15 .

191. Law No. 38 of 1972 (Concerning the People's Assembly), Al-jarida Al-Rasmiyya, 28 Sept. 1972 (Egypt). Despite the remaining flaws in Egypt's post-revolution electoral system, an unprecedented $70 \%$ of the electorate participated in the 2011-2012 parliamentary elections. BASSIOUNI, supra note 133, at 6 .

192. Bassiouni, supra note 133 , at 16 .

193. Analysis of the 2011 Parliamentary Electoral System, supra note 76, at 2.

194. See infra Part III.D.3.

195. Case no. 20/34/Constitutional Court (Egypt), available at http://www.earla.org/ news_events_detail.php?id=79 (unofficial English translation). 


\section{The Proportional Party Representation System}

In theory, proportional systems favor party agendas over a candidate's charisma, wealth, or personal political connections. Presumably, political parties will select the candidates most likely to succeed and be reelected in the next election. In contrast, an independent candidate system tends to favor wealthy individuals who may not be qualified to hold political office but are able to selffinance a political campaign. Because Egypt is in dire need of feasible solutions that address the intractable combination of rapid increases in poverty, overpopulation, a contracting industrial sector, and a dysfunctional education system, ${ }^{196}$ a proportional representation system may produce a more competent parliament. However, the proportional system excludes independent political activists operating outside the constraints of an arrangement where the dominant party retains control of government. ${ }^{197}$

Under the proportional party representation system, Law No. 38 of 1972 divides Egypt into forty-six proportional representation districts with the "average size of the People's Assembly multi-member districts is 7.2 seats per district, while the two-member majoritarian districts are much larger in size." 198 Within each district, the percentage of the total number of votes received by a given party determines the proportional number of seats allocated to that party. ${ }^{199}$ For example, if a party receives $25 \%$ of the votes in a fourseat district, that party is allocated one of the district's four seats.

196. See U.N. Dev. Programme, Reg'l Bureau for Arab States, Arab Human Development Report 2009: Challenges to Human Security in the Arab Countries (2009). Egypt's unemployment rate rose from $7.6 \%$ in the $1980 \mathrm{~s}$ to $9.6 \%$ in the 1990 s, and it is estimated that from 1980 through 2002, the Egyptian unemployment rate grew 2.2\%. Id. at $108-09$. Based on the upper national poverty line of $\$ 2.70$ per day, $40.93 \%$ of Egypt's total population and $52 \%$ of its rural population is living in poverty. Id. at 114 . The urban growth rate as of 2005 was close to a $2 \%$ annual increase, and from 2000 through 2005 Egypt had population growth close to $2 \%$. Id. at 35-36. The current state of Egypt's industrial development is significantly weaker compared to the 1960s and 70s. Id. at 103-05. National data from the region is heavily skewed due to the oil producing nations, of which Egypt is not a participant. Id. at 103. Egypt's informal, non-industrialized section makes up $40-50 \%$ of the country's economy. Id. at 11; see also The Role of Education in the Arab World Revolutions, BRoOKINGs INST. (June 1, 2011), http://www.brookings.edu/research/ opinions/2011/06/10-arab-world-education-winthrop ("These revolutions [in the Arab world] were not propagated by well-educated youth, ... [but] by the needs and demands of poorly educated youth, whose knowledge and skills do not meet the rising demands of a rapidly-advancing world.").

197. Moustafa, supra note 64, at 96.

198. Analysis of the 2011 Parliamentary Electoral System, supra note 76, at 3.

199. Law No. 38 of 1972 (Concerning the People's Assembly), Al-jarida Al-Rasmiyya, 28 Sept. 1972, art. 15 (Egypt). 
The proportional system vests significant discretion in party leadership who determine the order of candidates on party lists. ${ }^{200}$ Each party creates and publishes a candidate list for each district, with the number of listed candidates equal to the total number of seats in that district. ${ }^{201}$ Should a party win in a particular district, those candidates listed higher on the list receive priority placement over those listed below. ${ }^{202}$ For example, in a candidate list numbered one through six, the candidate listed third is given a seat only after the first and second candidate on the list are seated and before any candidates listed fourth, fifth, or sixth. Therefore, a candidate's positioning on the list determines his or her chances of attaining a seat. After determining its allocated number of seats based on the percentage of votes received, a party fills those seats according to its candidate list. ${ }^{203}$ Notably, most female candidates in the 2011 elections appeared at the bottom of each party's closed candidate list, ${ }^{204}$ resulting in only twelve women elected to the People's Assembly and five to the Shura Council. ${ }^{205}$ This is a significant reduction compared to the sixty-four women in the People's Assembly ${ }^{206}$ and eleven women in the Shura Council before the revolution. ${ }^{207}$

\section{The Independent Candidate System}

Under the independent candidate system, Law No. 38 of 1972 now divides Egypt into eighty-three districts with one seat contested by professionals and one seat contested by a farmer or worker in each district. ${ }^{208}$ Pursuant to a winner-take-all process, the candidate who obtains a majority of all valid votes wins a seat to the People's Assembly. ${ }^{209}$ Historically, independent candidate slots

200. Moustafa, supra note 64 , at 96 .

201. Law No. 38 of 1972 (Concerning the People's Assembly), Al-Jarida Al-Rasmiyya, 28 Sept. 1972, art. 15 (Egypt).

202. Id.

203. Id

204. Reem Leila, On Their Own, Al-Ahram WEEKLY (Nov. 24-30, 2011), http://weekly. ahram.org.eg/2011/1073/fo1 12.htm (listing the parties that placed female candidates at or near the bottom of their party list in the People's Assembly elections).

205. Results of Egypt's People's Assembly Election, supra note 189; Press Release, Carter Ctr., Preliminary Statement on Egypt's Shura Council Election (Feb. 28, 2012), http://www. cartercenter.org/news/pr/egypt-022812.html [hereinafter Press Release, Carter Ctr., Preliminary Statement].

206. Elections Held in 2010, supra note 127.

207. 44 Shura Appointments Include 8 Copts, EGrPT INDEP. (June 22, 2010), http://www. egyptindependent.com/node/51103.

208. Analysis of the 2011 Parliamentary Electoral System, supra note 76, at 3.

209. Id. (noting that majority vote is met by obtaining at least $50 \%$ plus one of votes). 
offered the only avenue for banned parties, such as the Muslim Brotherhood, to seek political representation in government. ${ }^{210}$ Hence, parties like the Muslim Brotherhood depended largely on a candidate-centered system for fielding independent candidates in parliamentary elections. ${ }^{211}$ In the post-revolution context, candidates with liberal or progressive leanings are likely to benefit from the independent candidate system because either the liberal parties are unable to compete with the Muslim Brotherhood's formidable party infrastructure or the candidate cannot find a political party with a similar political agenda. ${ }^{212}$

Meanwhile, the pre-revolution occupational requirement still applies as at least half of the seats in the People's Assembly remain allocated to "farmers" and "workers." 213 Under the proportional representation system, workers and farmers need not appear at the top of each party's candidate list; worker/farmer candidates, however, may not appear consecutively on a given list. ${ }^{214}$ Such favoritism towards farmers and workers incentivizes ambitious candidates to mischaracterize themselves to increase their chances of winning a parliamentary seat. ${ }^{215}$ As described in Part III(C) above, for seats contested through this form of independent candidate system each electoral district must seat at least one worker or farmer, complicating how votes are cast and winners are selected. ${ }^{216}$

The most significant post-revolution amendment to Law No. 38 governing the People's Assembly elections is the removal of the sixty-four-seat quota for female candidates, which effectively shuts out women from the lower house of parliament. ${ }^{217}$ Without the quota, only a handful of women will be elected to office-as exem-

210. Hany Besada, Egypt's Constitutional Test. Averting the March Toward Islamic Fundamentalism 3 (Ctr. for Int'l Governance Innovation, Working Paper No. 28, 2007), available at http://cigionline.cigiprojects.org/publications/2007/8/egypts-constitutional-test-avertingmarch-toward-islamic-fundamentalism.

211. Id.; Moustafa, supra note 64, at 197 (describing the Muslim Brotherhood's historic win of seventeen independent seats in the 2000 parliamentary elections, which was more than all candidates standing for election from the formal opposition parties combined).

212. Amr Hamzawy, for example, was a candidate of the Egypt Freedom Party. Amr Hamzauy, Ahram Online (Nov. 19, 2011), http://english.ahram.org.eg/NewsContent/33/ 102/26711/Elections-/Whos-who/Amr-Hamzawy.aspx.

213. Law No. 38 of 1972 (Concerning the People's Assembly), Al-jarida Al-Rasmiyya, 28 Sept. 1972, art. 1 (Egypt).

214. Analysis of the 2011 Parliamentary Electoral System, supra note 76, at 3.

215. Charbel, supra note 162 (highlighting the fraudulent use of broad union recognition to allow business people to run as "workers"; the very small amount of land needed to qualify as a "farmer"; and the abuse of these lax standards by business people and officers).

216. See Analysis of the 2011 Parliamentary Electoral System, supra note 76, at 3.

217. See Leila, supra note 204. 
plified in the 2011 elections where only nine women were elected to the People's Assembly. ${ }^{218}$ It is worth acknowledging the paradox created by quotas. On the one hand, purely democratic elections are not constrained by quotas that advantage a particular group over another. On the other hand, it is a fallacy that all citizens have equal opportunity to run for political office. ${ }^{219}$ Disparities in income and social status coupled with cultural bias against particular groups impede equal opportunity, thereby warranting affirmative measures that remedy entrenched disadvantages. ${ }^{220}$ Thus, a purely democratic system adopted after years of authoritarian rule merely reinforces inequities that are the byproducts of authoritarianism.

In the 2011 parliamentary elections, women performed poorly under the proportional representation system because parties, required by law to include them, consistently placed women candidates at the bottom of their lists. ${ }^{221}$ Furthermore, few women have the economic resources and political clout to be elected under the independent candidate system by voters who are disinclined to vote women into political office. ${ }^{222}$ Such distorted outcomes undermine the legitimacy of the government as Egyptian women question the parliament's ability to adequately represent their interests in a country where women's rights have historically been marginalized.

218. Results of Egypt's People's Assembly Election, supra note 189 (documenting that nine women were elected to the People's Assembly and that SCAF appointed three).

219. Analysis of the 2011 Parlamentary Electoral System, supra note 76, at 10-11 (noting that Egypt's electoral laws deny certain societal groups representation (e.g., Coptics and women)).

220. See Drude Dahlerup \& Lentta Freidenvall, Directorate Gen. Internal Policies of the Union, Electoral Gender Quota Systems and Their Implementation in Europe 19,48 (2008).

221. Analysis of the 2011 Parliamentary Electoral System, supra note 76, at 10 (explaining that women placed second or third on a party's candidate list have a far less chance of winning than those listed first or simply higher).

222. See Nazra for Feminist Studies, She and Elections: Mentorinc on the Ground WITH THE CANDIDATES 2011/2012, at 3, 5, 11, 15 (2012); AMnesty INT'L, supra note 187, at 1 (noting that "misguided views about women's ability or right to be involved in politics are also prevalent, especially in rural areas"). Such outcomes are precisely why the quotas were instituted. Hala Mustafa et al., Int'l Inst. for Democracy \& Electoral Assistance, Building Democracy in Egypt: Women's Political Participation, Political Party Life and Democratic Elections 14 (2005), available at http://www.idea.int/publications/ dem_egypt/upload/Egypt_country_report_English.pdf. 


\section{Creation of a Mixed Electoral System for Parliamentary Elections}

As the prior two Sections illustrate, the SCAF's Decree 108 of 2011 created a mixed electoral system for both houses of parliament comprised of winner-take-all independent candidates and proportional party representation districts. Decree No. 108 was a compromise law promulgated after a highly contentious debate between the Muslim Brotherhood's Freedom and Justice Party, the SCAF, liberal parties, and civil society organizations. ${ }^{223}$ In May 2011, the SCAF proposed a draft parliamentary election law that preserved the winner-take-all-district system and the occupational requirements applicable to two-thirds of the People's Assembly. ${ }^{224}$ Candidates would contest the remaining one-third of the seats through a proportional representation system. ${ }^{225}$ In response to political parties' concerns that the former regime misused gender quotas to select female NDP supporters, rather than as a mechanism to empower women in politics, Decree 108 of 2011 abolished the sixty-four-seat quota reserved for female candidates. ${ }^{226}$

With regard to the proportional representation system, political parties and the SCAF were unable to agree on the minimum number of votes required for a party to obtain a parliamentary seat. ${ }^{227}$ The initial draft law failed to address many important facets of the electoral process, including the size of parliament, the allocation of seats to each governorate, the formula for allocating proportional representation seats, and the issue of Egyptian expatriates voting abroad. ${ }^{228}$ Thus, most political parties rejected the May $2011 \mathrm{draft}$ law. ${ }^{229}$

In July 2011, the SCAF proposed a second draft election law that set the People's Assembly at 504 members and the Shura Council at 390 members, of which 260 would be elected and 130 appointed. ${ }^{230}$ Under this draft, $50 \%$ of all parliamentary seats

223. Analysis of the 2011 Parliamentaky Electoral System, supra note 76, at 2-3.

224. See id. at 2.

225. See id.

226. What Does Egypt's Parliament Look Like?, BBC (Jan. 24, 2012), http://www.bbc.co. $\mathrm{uk} /$ news/magazine-16701937. With the dissolution of the NDP, concern over abuse of the quota became moot and served only to penalize women by excluding them from elected office. See id. (noting that women only hold around 1 percent of the seats in the new assembly). Moreover, alternative means exist to address quota abuse concerns without penalizing women for the NDP's corruption.

227. Analysis of the 2011 Parliamentary Electoral System, supra note 76, at 2.

228. See id.

229. See id.

230. See id. 
would be elected through the proportional representation system and the other $50 \%$ through the independent candidate district system. ${ }^{231}$ To facilitate this dual system, the law created fifty-eight proportional representation districts for the People's Assembly and twenty-eight Shura Council proportional representation districts. $^{232}$ The July 2011 draft maintained the occupational requirement, and, while it also abolished the quota for women, it required that each party include at least one woman anywhere on their party lists in proportional representation districts. ${ }^{233}$

Political parties and civil society organizations opposed the July 2011 draft election law out of concern that prominent ex-NDP members would take advantage of the independent candidate system applicable to half the seats of parliament, resulting in the reemergence of the NDP in parliament. ${ }^{234}$ Instead, political parties demanded a "closed-list" 235 proportional representation system where voters choose a candidate from a party's fixed list of candidates, rather than an individual candidate. ${ }^{236}$ The parties argued that this system simultaneously weakens the significance of individual candidates, including former NDP members, and empowers political parties to control which candidates run in parliamentary elections. ${ }^{237}$

This concern has particular salience in Egypt because voters historically select candidates based on familial allegiances, instructions by village elders, or the candidates' political connections. ${ }^{238}$ Deeply entrenched cronyism has produced little by way of economic and social development for constituents. ${ }^{239}$ To the contrary,

231. See id.

232. See id.

233. See id.

234. See id. at 3.

235. A closed list is one in which the order of the candidates on the list is fixed at the time of registration. See $i d$. at 6 .

236. News Wires, Egyptian Military Amends Controversial Election Law, FR. 24 (Oct. 9, 2011), http://www.france24.com/en/20111008-egypt-military-election-law-president-legislative-candidates.

237. Analysis of The 2011 Parliamentary Electoral System, supra note 76, at 3; see also Charles Levinson, Surprise Rise of Mubarak Loyalist, WaLl St. J. (May 30, 2012), http:// online.wsj.com/article/SB10001424052702303674004577434562867892748.html (reporting that Coptic "vote for Shafiq was spread by word of mouth, in churches"); Richard Spencer, Egypt Decides Between Army and Mosque, Telegraph (May 22, 2012), http://www. telegraph.co.uk/news/worldnews/africaandindianocean/egypt/9283646/Egypt-decidesbetween-army-and-mosque.html (reporting the observation of an imam in a small town giving a public sermon implying who the congregation should vote for).

238. Lisa Blaydes, Elections and Distributive Politics in Mubarak's Egypt 107 (2011).

239. Id. at 108 . 
elected officials typically use their positions to engage in self-dealing and personal enrichment. ${ }^{240}$ Hence, requiring voters to select political parties, instead of individuals, presumably shifts political power to those with developed political agendas. ${ }^{241}$

In September 2011, the SCAF introduced a third draft election law following its official announcement that parliamentary elections would begin in November 2011.242 Partially accepting the political parties' demands, the amendments allocated a third of the seats through the independent candidate winner-take-all system and the remaining two-thirds through a "closed list" proportional representation system. ${ }^{243}$ The amendments also reduced the size of the elected People's Assembly and Shura Council to 498 and 180 , respectively. 244

Political parties again rejected these changes. Members of the Freedom and Justice Party, the Wafd Party, and other political parties criticized the amendments for failing to incorporate their suggestions made during consultations with the SCAF. ${ }^{245}$ As a result, the parties threatened to boycott parliamentary elections altogether if the September 2011 draft became law.246 Much of the criticism focused on Article 5 of Decree No. 120 of 2011, which prohibited any candidate belonging to a political party from running in a two-member independent candidate district and forbade any elected independent candidate from subsequently joining a political party while in parliament. ${ }^{247}$ Civil society organizations and political parties sought to repeal the article, arguing that the exclusion of party-backed candidates favors wealthy businessmen

240. See David D. Kirkpatrick \& Heba Afify, Steel Tycoon with Links to Mubarak Is Sentenced, N.Y. Times (Sept. 15, 2011), http://www.nytimes.com/2011/09/16/world/middleeast/egypt-sentences-mubarak-era-tycoon-ahmed-ezz-to-prison.html (noting that during the Mubarak regime, prominent NDP Parliamentarian Ahmed Ezz used his political clout to engage in self-dealing transactions that benefitted Ezz Steel, the leading steel producer in the Middle East, which was owned by Ezz).

241. BLAYDES, supra note 238, at 54 (noting that elections in Egypt are a sorting mechanism for the distribution of resources and access to state largess and that electoral competition came to be viewed less as a means for reforming the government or the economy than as a way to enhance social prestige and personal wealth and influence).

242. Analysis of the 2011 Parliamentary Electoral System, supra note 76, at 2.

243. Parliamentary Elections Law, Carnegie Endowment for Int'L Peace, http:// egyptelections.carnegieendowment.org/2011/10/04/parliamentary-elections-law (last visited Jan. 9, 2012).

244. See id.

245. See id.

246. Analysis of the 2011 Parliamentary Electoral System, supra note 76, at 3.

247. Decree Law No. 120 of 2011 (To Amend Provisions of Law No. 38 of 1972 on the People's Assembly and Law No. 120 of 1980 on the Shura Council), 27 Sept. 2011, art. 5 (Egypt). 
and former NDP members whose financial resources and political clout would give them an unfair advantage over other independent candidates. ${ }^{248}$ In the wake of this collective rebuke and the election boycott threat, the SCAF repealed Article 5 of Decree No. 120 of 2011 in Decree No. 123 of 2011.249 The decision to remove the bar on independent candidates joining political parties and to permit party candidates to run for independent slots districts with two seats proved fatal, as it later became the basis for the SCC's dissolution of parliament in June 2012. ${ }^{250}$

The final versions of Decrees No. 108, 110, and 120 created a mixed electoral system for both houses of parliament comprised of winner-take-all independent candidates and proportional party representation districts. ${ }^{251}$ The Decrees set the People's Assembly's membership to 504, with 498 members elected through the mixed electoral system and ten members appointed by the president of the republic. ${ }^{252}$ The Shura Council's membership was set to 270 , with 180 members elected through the mixed electoral system and ninety appointed by the president of the republic. ${ }^{253}$ For both the People's Assembly and the Shura Council, two-thirds of the elected seats are elected through proportional party representation with "closed" party lists and a one-third by winner-take-all independent candidate process. ${ }^{254}$

As described above, the Decrees also abolish the sixty-four-seat quota for female candidates, requiring instead that parties place at least one female candidate on each party list. ${ }^{255}$ However, females were consistently listed at the bottom of party lists during the 20112012 parliamentary elections. ${ }^{256}$ As a result of those elections, only

248. Analysis of the 2011 Parlamentary Electoral System, supra note 76, at 3.

249. Decree Law No. 123 of 2011, 8 Oct. 2011, art. 1 (Egypt).

250. Case no. 20/34/Constitutional Court (Egypt), available at http://www.earla.org/ news_events_detail.php?id=79 (unofficial English translation).

251. See Decree Law No. 108 of 2011 (Concerning Amendments to Law No. 38)), art. XV (Egypt); Decree Law No. 120 of 2011 (To Amend Provisions of Law No. 38 of 1972 on the People's Assembly and Law No. 120 of 1980 on the Shura Council), 27 Sept. 2011, art. 12 (Egypt).

252. See Law No. 38 of 1972 (Concerning the People's Assembly), Al-Jarida Al-Rasmiyya, 28 Sept. 1972, art. 1 (Egypt).

253. Decree Law No. 120 of 2011 (To Amend Provisions of Law No. 38 of 1972 on the People's Assembly and Law No. 120 of 1980 on the Shura Council), 27 Sept. 2011, art. 3 (Egypt); Law No. 120 of 1980 (Concerning the Shura Council), Al-jarida Al-Rasmiyya, 3 July 1980 , art. 1 (Egypt).

254. Analysis of the 2011 Parliamentary Electoral System, supra note 76, at 3.

255. Bassiouni, supra note 133 , at 16 .

256. Lourdes Garcia-Navarro, In Egypt's New Parliament, Women Will Be Scarce, NPR (Jan. 19, 2012), http://www.npr.org/2012/01/19/145468365/in-egypts-new-parliament-womenwill-be-scarce. 
twelve women were elected or appointed by the SCAF to the People's Assembly and two to the Shura Council.257

Ultimately, after a protracted three month election process involving three rounds of voting across the country, the parliament was dissolved by an SCC decision that struck down Decrees No. 120 and 123 as unconstitutional. ${ }^{258}$ The SCC found two fundamental flaws with the new election laws. First, granting independent candidates a chance to win only one-third of the People's Assembly violated the principle of equality and equal opportunity ensured by Article 7 of the Constitutional Declaration. ${ }^{259}$ Second, allowing independent candidates to join political parties after being elected created an unequal advantage where parties ran purportedly independent candidates who later formally joined the party. ${ }^{260}$ By permitting those belonging to political parties to choose two separate paths to gain membership into the People's Assembly-the closed party list system as well as the individual candidacy systemDecrees No. 120 and 123 violated Article 7 of the Constitutional Declaration. ${ }^{261}$

To the surprise of the political class, the SCC's recommended remedy was dissolution of the People's Assembly instead of disqualification of independent candidates. ${ }^{262}$ The Court reasoned that Decrees No. 120 and 123 violated all citizens' political rights, including the rights of candidacy and voting in elections and referenda. ${ }^{263}$ The Court found that preserving citizens' political rights was critical to ensure their participation in public life, as such rights are the democratic means to express their opinions and elect their representatives in the administration of government in the country. ${ }^{264}$ Thus, a voter's right to choose the candidates that represent their interests was tantamount to their constitutionally protected political rights. Moreover, any distinction based on party affiliation created an unfair advantage to some candidates based on political opinion, which was constitutionally prohibited. ${ }^{265}$ As a

257. Results of Egypt's People's Assembly Election, supra note 189; Press Release, Carter Ctr., Preliminary Statement, supra note 205 (noting that of the 678 members of parliament, only fourteen are women).

258. See Case no. 20/34/Constitutional Court, (Egypt), available at http://www.earla. org/news_events_detail.php?id=79 (unofficial English translation).

259. Id.

260. Id.

261. Id.

262. Id.

263. Id .

264. Id.

265. Id 
result, the Court found that the formation of the parliament in its entirety was invalid, thereby ordering its dissolution. ${ }^{266}$

\section{E. Minimal Changes to the Shura Council after the Revolution-Law No. 120 of 1980}

Upon taking office in 1970, President Anwar al-Sadat embarked on a series of reforms that began an era of political and economic liberalization. ${ }^{267}$ Known as infitah al-iqtisadi, Sadat's reforms allowed previously banned political parties to re-enter political life under a tightly controlled process that ensured the dominance of the executive branch. ${ }^{268}$ Sadat sought to create a "state of institutions," whereby citizens would have access to justice and participation in public life through executive agencies and procedures within the executive branch. ${ }^{269}$ In furtherance of his vision, Sadat expanded the Egyptian parliament by establishing an upper house known as the "Shura Council" that was comprised of 264 members. ${ }^{270}$ Subsequently, Articles 194 through 205 were added to the constitution and Law No. 120 of 1980 was promulgated to fulfill Sadat's political agenda. ${ }^{271}$

\section{A Powerless Legislative Body}

Articles 194 through 205 of the 1971 Constitution create the Shura Council and specify its responsibilities as the upper house of parliament. ${ }^{272}$ Legislatively, the Shura Council is limited to approving the following ${ }^{273}$ : (1) proposed constitutional amendments; (2)

266. $I d$.

267. Thomas W. Lippman, Egypt After Nasser: Sadat, Peace and the Mirage of ProsPERITY, ch. 1 (1989).

268. See Moustafa, supra note 64 , at 90 .

269. See Lippman, supra note 267, ch. 1 .

270. Law No. 120 of 1980 (Concerning the Shura Council), Al-jarida Al-Rasmiyya, 3 July 1980 (Egypt).

271. See Constitution of the Arab Republic of Egypt, 11 Sept. 1971, as amended, May 22, 1980, May 25, 2005, March 26, 2007; Law No. 120 of 1980 (Concerning the Shura Council), Al-jarida Al-Rasmiyya, 3 July 1980 (Egypt).

272. Law No. 120 of 1980 (Concerning the Shurah Council), Al-Jarida Al-Rasmiyya, 3 July 1980 (Egypt). Law No. 120 of 1980 governs the Shura Council. Id. art. 1. It establishes a 264-member upper house of parliament, with two-thirds of the members elected by the people and the remaining one-third appointed by the president. Id. art. 3 . All members serve six-year terms. Id. art. 6 . Law No. 120 stipulates that a candidate must be at least thirty-five years old, hold a basic education completion certificate, and complete the obligatory military service. Id. arts. 7-8. It also establishes the method for nominating a candidate for appointment to the Shura Council. See id.

273. Constitution of the Arab Republic of Egrpt, 11 Sept. 1971, as amended, May 22, 1980, May 25, 2005, March 26, 2007; Law No. 120 of 1980 (Concerning the Shura Council), Al-jarida Al-Rasmiyya, 3 July 1980 (Egypt). 
draft laws designed to implement certain constitutional provisions; ${ }^{274}$ and (3) peace and alliance treaties, and any treaty that affects the territorial integrity or sovereign rights of the State. ${ }^{275}$ The Shura Council merely consults with the president of the republic and the People's Assembly regarding276: (1) drafts of general plans for social and economic development; (2) draft laws submitted to the People's Assembly by the president; and (3) matters referred to the People's Assembly by the president relating to the general policy of the State. ${ }^{277}$ In addition, the Shura Council issues reports and submits non-binding recommendations to the president and People's Assembly on matters it deems necessary to preserve national unity and the basic foundations of society. ${ }^{278}$ None of the Shura Council's recommendations are binding on the president or the People's Assembly, ${ }^{279}$ making it a relatively powerless institution.

The Shura Council has long been the subject of criticism by the Egyptian people for its lack of legislative power and susceptibility to political cronyism and patronage. ${ }^{280}$ When it was established in 1980, President Sadat envisioned it as a body of intellectuals and technocrats offering non-binding advice to the ministerial cabinet and the People's Assembly. ${ }^{281}$ Beyond its executive advisory role, the Shura Council oversees various government-run "national councils," whose duties range from establishing journalistic guidelines to approving new political parties. ${ }^{282}$ Within these regulatory authorities, the Shura Council has the potential to significantly influence civil society and the democratic process, but remains outside of the formal legislative process. ${ }^{283}$ For instance, the Shura Council controls the committees that regulate the media and regis-

274. Constitution of the Arab Republic of Egypt, 11 Sept. 1971, as amended, May 22, 1980, May 25, 2005, March 26, 2007.

275. Id.

276. Id.

277. Id:; see Law No. 120 of 1980 (Formation of the Shura Council), Al-Jarida Al-Rasmiyya, 3 July 1980, art. 195 (Egypt).

278. Constitution of the Arab Republic of Egypt, Sept. 11, 1971, as amended, May 22, 1980, May 25, 2005, March 26, 2007; Law No. 120 of 1980 (Concerning the Shura Council), Al-Jarida Al-Rasmiyya, 3 July 1980, art. 195 (Egypt).

279. Heba Affify, Abdel Rahman Hussein \& Christine Kassasseya, Shura Council Elections Underway, but Many Ask: What's the Point?, Egrpt INDEP. (Jan. 30, 2012), http://www.egypt independent.com/node/628356.

280. See id.

281. See id.

282. Id .

283. See id. 
tration of new political parties. ${ }^{284}$ The Mubarak regime used these powers to quash political dissent and creation of viable political opposition parties. 285

The rampant corruption under Mubarak and his predecessors inhibited the Shura Council's potential to strengthen civil society and bolster democracy in Egypt. Critics often described the Shura Council as little more than a patronage tool employed by President Mubarak and the ruling NDP to reward loyal members. ${ }^{286}$ A notorious example is Safwat El-Sherif, who served as Mubarak's minister of information for twenty-two years, beginning in 1981.287 In 2004, Mubarak promoted El-Sherif to chairman of the Shura Council's High Consultative Committee. This made El-Sherif by law the chairman of the influential Political Parties Committee, which licenses political parties, and the Supreme Press Council, which appoints chief editors and board chairmen of state-owned press organizations. ${ }^{288}$ As chairman of the Political Parties Committee, El-Sherif blocked many opposition forces from obtaining licenses to form opposition parties. ${ }^{289}$ As chairman of the Higher Press Council, El-Sherif wielded his influence to ensure that state-owned newspapers and magazines drummed up support for Mubarak as Egypt's indispensable leader. ${ }^{290}$

Through vote-rigging and elections fraud, the NDP won most of the Shura Council's contested two-third seats. ${ }^{291}$ Meanwhile, President Mubarak routinely exercised his power to appoint one-third of the Shura Council in favor of NDP members, giving the ruling party a virtual monopoly over the Shura Council. ${ }^{292}$ The NDP exploited its political dominance of the Shura Council to regulate the press and deny licenses for political opponents seeking to form new political parties. ${ }^{293}$ As a result, there have been numerous calls for its abolition before and after the January 25 Revolution. ${ }^{294}$

284. Toby Mendel, Political and Media Transitions in Egypt: A Snapshot of Media Policy and Regulatory Environment 7-10 (2011) (reporting the Shura Council's regulation of the media).

285. See id. at 5-10.

286. Affify, Hussein \& Kassasseya, supra note 279.

287. Gamal Essam El-Din, El-Sherif, Sorour and Azmi: Mubarak's Top Henchmen at Jail's Doors, Ahram Online (Apr. 10, 2011), http://english.ahram.org.eg/NewsContentP/1/ 9673/Egypt/ElSherif,-Sorour-and-Azmi-Mubaraks-top-henchmen-at.aspx.

288. Id.

289. Id.

290. Id.

291. BLAYDES, supra note 238 , at 40 .

292. Affify, Hussein \& Kassasseya, supra note 279.

293. Blaydes, supra note 238, at 40, 112.

294. Affify, Hussein \& Kassasseya, supra note 279. 


\section{The Same Shura Council after the Revolution}

In contrast to those concerning the People's Assembly, the laws governing the Shura Council elections underwent minimal postrevolution changes. In Decree No. 120 of 2011, the SCAF decreased the minimum age for Shura Council candidates from thirty to twenty-five, ${ }^{295}$ increased the total seats from 264 to 270 seats, and increased the number of appointed seats from eightyeight to ninety. ${ }^{296}$ Consequently, the president continues to wield significant influence over the Shura Council. Nevertheless, the post-revolution Shura Council still lacks the authority to promulgate legislation, ${ }^{297}$ thus limiting its ability to affect legal reforms. As a consequence, only $10 \%$ of eligible voters participated in the 2012 Shura Council election, compared with the $70 \%$ that participated in the People's Assembly elections. ${ }^{298}$

Of the 180 contested seats, two-thirds (120 seats) are elected through the proportional representation system and one-third (sixty seats) are elected through the independent candidate system. ${ }^{299}$ The 180 elected members elected from thirty-two-member independent candidate districts and thirty-four-member proportional representation districts. ${ }^{300}$ The same rules and considerations governing the independent candidate and proportional systems in the People's Assembly, including the workers and farmers quota, apply to the Shura Council elections. ${ }^{301}$

To the extent that Egyptians have the political will to transform the Shura Council into a traditional upper house of parliament with attendant legislative powers, there is much room for reform. ${ }^{302}$ One of two reforms should occur. Either the Shura Council should be transformed into an upper house of parliament with legislative authorities to make law, or the Shura Council should be abolished to prevent the executive branch from exploit-

295. Bassiouni, supra note 133 , at 15.

296. Decree Law No. 120 of 2011 (To Amend Provisions of Law No. 38 of 1972 on the People's Assembly and Law No. 120 of 1980 on the Shura Council), 27 Sept. 2011 (Egypt).

297. See generally Law No. 120 of 1980 (Concerning the Shura Council), Al-jarida AlRasmiyya, 3 July 1980 (Egypt) (illustrating the Shura Council's inability to make laws by way of enumerating all of its responsibilities).

298. See Bassiouni, supra note 133, at 19, 22.

299. Id. at 15. The population in each district is approximately the same, thereby justifying an equal number of political representatives per district. Carter Ctr., Preliminary

Report on All Three Phases of the People's Assembly Elections 7 (2012).

300. Analysis of the 2011 Parliamentary Electoral System, supra note 76, at 6.

301. See supra Part III.D-E (describing Egypt's proportional representation and independent candidate election systems in detail).

302. Affify, Hussein \& Kassasseya, supra note 279. 
ing it to diminish powers of the People's Assembly, unduly politicize civil society, and impede the formation of a free press. ${ }^{303}$

\section{F. Presidential Elections before the Revolution-Law No. 174 of 2005}

Before the January 25 Revolution, it was onerous for a non-NDP candidate to get on the presidential ballot. Law No. 174 of 2005 created numerous regulatory hurdles for newcomers to overcome, resulting in the de facto dominance of the ruling NDP party. A presidential candidate had to obtain at least 250 written endorsements from elected members of the People's Assembly, the Shura Council, and local popular councils at the governorate level. ${ }^{304}$ Of the 250 endorsements, at least sixty-five must come from members of the People's Assembly, twenty-five from members of the Shura Council, and ten from every local council in at least fourteen governorates. ${ }^{305}$ Similarly, a candidate's political party must have been "founded at least five years before the starting date of candidature and have been operating uninterruptedly for this period," and its members must "have obtained at least $5 \%$ of the elected members of both the People's Assembly and the Shura Council[.]"306

Although the revolution effectively purged the NDP from its ruling party status, existing laws can foreseeably produce the same result, but for a different ruling party. Hence, there is merit to ongoing calls for reform of the presidential election law. Specifically, parliament should reform the presidential nomination process to allow more minority parties and independent candidates to enter the presidential race..$^{307}$ In addition, reformation of the presidential election monitoring would assure fair and free elections. ${ }^{308}$

\section{The Presidential Nomination Process}

Pre-revolution, Law No. 174 of 2005 established the qualifications for presidential candidates and the mechanism for supervis-

303. Ammar Ali Hassan, Written on the Wall, Al-Ahram WeEkly Online (Feb. 23-29, 2012), http://weekly.ahram.org.eg/2012/1086/op7.htm; Affify, Hussein \& Kassasseya, supra note 279; Egypt's New Constitution Likely to Retain Shura Council, Global Times (Sept. 30, 2012), http://www.globaltimes.cn/content/736157.shtml (reporting on the contentions within the Constitutional Assembly committee about the future role of the Shura Council).

304. Law No. 174 of 2005 (Regulating the Presidential Elections), Al-Jarida Al-Rasmiyya, 2 July 2005, art. 2 (Egypt).

305. Id.

306. Id. art. 3 (emphasis added).

307. See Stilt, supra note 24 , at 354-55.

308. Id. at 363-64. 
ing the presidential elections. ${ }^{309}$ Under this law, a candidate for president could qualify in one of two ways. Under the first nomination method a candidate was required to: (1) be an Egyptian citizen with Egyptian parents and not hold any other nationality; ${ }^{310}$ (2) complete his obligatory military service or receive an exemption certificate; ${ }^{311}$ and (3) receive written endorsement from at least 250 elected members of the People's Assembly, Shura Council, and local popular councils on the governorate level. ${ }^{312}$ Alternatively, a political party that obtained a single seat in the People's Assembly or the Shura Council in the most recent elections could nominate a presidential candidate who has been a member of its board for at least one year. ${ }^{313}$

The pre-revolution presidential nomination process favored large parties with a significant representation in parliament. ${ }^{314}$ Unless the parliament was composed of numerous political parties, small or new parties were unlikely to obtain the required 250 signatures to nominate a presidential candidate under the first nomination method. ${ }^{315}$ Similarly, independent candidates were de facto excluded from running for president. ${ }^{316}$ As discussed in more detail below, this was problematic because the presidential nomination process should provide the electorate with meaningful choices beyond the most powerful and entrenched political parties. ${ }^{317}$

The second nomination method required a nominee to be a senior board member of a political party with at least one seat in parliament. ${ }^{318}$ In 2005, this nomination method resulted in eight presidential candidates running against President Mubarak in

309. Id. at 353 .

310. See Law No. 174 of 2005 (Regulating the Presidential Elections), Al-Jarida Al-Rasmiyya, 2 July 2005, art. 13 (Egypt) (emphasis added) (requiring applicant to declare that "he is an Egyptian citizen from Egyptian parents that he does not hold any other nationality").

311. See id. (requiring a document verifying "a military service completion or exemption certificate").

312. Id. art. 2; Stilt, supra note 24 , at 349-50, 354-55.

313. Law No. 174 of 2005 (Regulating the Presidential Elections), Al-jarida Al-Rasmiyya, 2 July 2005, art. 13 (Egypt) (emphasis added).

314. Stilt, supra note 24 , at $346,349-50,353-55$.

315. Id. at 349-50, 353-57.

316. Id. at $349-50$.

317. See infra Part V.

318. Law No. 174 of 2005 (Regulating the Presidential Elections), Al-Jarida Al-Rasmiyya, 2 July 2005, art. 4 (Egypt); Stilt, supra note 24 , at 349-50, 353-57. 
Egypt's first multi-party presidential elections. ${ }^{319}$ Ayman Nour, ${ }^{320}$ leader of the liberal Al-Ghad Party, fared best among non-NDP candidates, garnering $12 \%$ of the vote despite reports of widespread election fraud and voter intimidation. ${ }^{321}$ In the year of the election, Nour was charged by the government for forging documents used to create his political party, resulting in a five-year prison sentence. ${ }^{322}$ Nour's plight was widely criticized by foreign governments as politicized attempts to stifle political dissent in Egypt. ${ }^{323}$

The enactment of Law No. 173 in 2005 also fortified the ruling NDP's domination of the parliament. ${ }^{324}$ Indeed, in 2010, non-NDP parties won about 3\% (15 of 504 seats) in the People's Assembly as opposed to $22 \%$ in 2005 (98 of 444 seats). ${ }^{325}$ Parliamentary representation by non-NDP parties became virtually non-existent. The New Wafd Party, for example, held a mere six seats $1.1 \%$ of all seats) despite being the largest opposition party in $2010 .{ }^{326}$ As a practical matter, the overwhelming NDP presence in the parliament prohibited any political party with less than $5 \%$ of the parliamentary seats from fielding a presidential candidate. ${ }^{327}$ Thus, the NDP monopolized the Presidency. ${ }^{328}$

Alternatively, Law No. 174 of 2005 allowed a political party with at least a single seat in parliament to nominate a senior member of its board as a presidential candidate, thus providing an avenue for

319. The eight candidates standing against President Mubarak in 2005 were Ayman Nour (Al-Ghad Party), Numan Gumaa (Wafd Party), Osama Shaltut (Solidarity Party), Ibrahim Turk (Democratic Union Party), Ahmad Al-Sabahi (Umma Party), Fawzi Ghazal (Egypt 2000 Party), Mamduh Qinawi (Constitutional Party), and Rifaat Al-Agrudi (National Concord Party). Profiles: Egypt's Presidential Hopefuls, BBC News, http:// news.bbc.co.uk/2/hi/middle_east/4193132.stm (last updated Sept. 2, 2005).

320. Ayman Nour is an Egyptian lawyer, former parliamentarian, and founder of the liberal Al-Ghad Party. Ayman Nour, CARnegie Endowment for INT'L Peace, http:// egyptelections.carnegieendowment.org/2010/09/09/profile-of-ayman-nour (last visited Jan. 9, 2013); Profile: Ayman Nour, BBC (Dec. 24, 2005), http://news.bbc.co.uk/2/hi/ $4558054 . \mathrm{stm}$.

321. Mubarak Wins Egypt Vote, CBS News (Feb. 11, 2009), http://www.cbsnews.com/ stories/2005/09/08/world/main828234.shtml.

322. Ayman Nour, supra note 320.

323. See Profile: Ayman Nour, supra note 320.

324. Egypt's Election Primer, CARnegie Endowment for INT'L Peace, http://egyptelections.carnegieendowment.org/2010/09/10/egypt's-elections-primer (last visited Jan. 9, 2013); Stilt, supra note 24, at 346.

325. Egypt's Election Primer, supra note 324.

326. See id.

327. Stilt, supra note 24 , at 349-50.

328. See id. 
minority parties to nominate a presidential candidate. ${ }^{329}$ With these changes to nomination requirements, in the 2005 presidential elections, several political parties were able to run a presidential candidate against Hosni Mubarak. ${ }^{330}$ Prior to these changes, the only nomination method available required political parties to operate for at least five consecutive years and obtain at least $5 \%$ of the seats in both houses of parliament. ${ }^{331}$ Consequently, political parties faced the specter of meeting a significantly higher threshold in order to nominate a candidate, which would have effectively prohibited many small-party candidates from running in presidential elections. ${ }^{332}$ This may incentivize smaller parties to form coalitions. Law No. 174 of 2005, however, was silent as to whether a coalition of parties that collectively could meet this heightened standard may nominate a candidate.

Both nomination methods effectively prevented independent candidates from running in presidential elections. ${ }^{333}$ Under the nomination method requiring endorsement of 250 members of parliament, independent candidates often lacked the political connections and party ties needed to secure support from a sufficient number of parliament members. ${ }^{334}$ Similarly, the nomination method through membership in a political party offered no avenue for independent candidates to run for president because they would have to officially create a party, but with the strict guidelines, creating a party was rarely a feasible option. ${ }^{335}$

Both nomination methods also granted major political parties significant advantages. Under the pre-revolution version of Law 174 , the field of presidential candidates would be limited to those who compromise their party's platform in exchange for support from the major parties. Large parties could also leverage their influence to extract political concessions from smaller parties. Under the pre-revolution law, voters were denied the opportunity to select from a diverse candidate pool. ${ }^{336}$

329. Law No. 174 of 2005 (Regulating the Presidential Elections), Al-jarida Al-Rasmiyya, 2 July 2005, art. 4 (Egypt); see also Stilt, supra note 24, at 349-50, 353-57.

330. Int'l Republican Inst., Final Report: 2005 Presidential Election Assessment in EGYPT 3 (2005).

331. Law No. 174 of 2005 (Regulating the Presidential Elections), Al-Jarida Al-Rasmiyya,

2 July 2005, art. 3 (Egypt) (Article 3 was abrogated in 2012 by Decree Law No. 12.).

332. Stilt, supra note 24 , at $354-57$.

333. Id.

334. Id. at 349-50, 353-57.

335. Id.

336. Mallat et al., supra note 1 , at 186 . 


\section{The Presidential Elections Commission}

Article 76 of the abrogated 1971 Constitution establishes the PEC to supervise presidential elections. ${ }^{337}$ Similar to the HEC, the PEC prior to the revolution was a distinct legal entity composed of judges and individuals beholden to the dominant political party that appointed them. ${ }^{338}$ The PEC was composed of: (1) the Head of the SCC, as chair;339 (2) the Head of the Cairo Court of Appeal; ${ }^{340}$ (3) the most senior deputy judge of the SCC; ${ }^{341}$ (4) the most senior deputy judge of the Supreme Court ("Court of Cassation"); ${ }^{342}$ (5) the most senior deputy judge of the State Council;343 and (6) five public figures "recognized for their impartiality," three of whom are chosen by the People's Assembly and two by the Shura Council upon a recommendation of the bureaus of both chambers. ${ }^{344}$

The PEC's primary functions were to: (1) declare the opening of the candidate selection process and supervise procedures for fixing the final list of candidates; ${ }^{345}$ (2) supervise balloting and votecounting procedures; ${ }^{346}(3)$ receive and examine candidate applications, and verify that they meet relevant requirements; ${ }^{347}$ (4) announce election results; ${ }^{348}(5)$ rule on appeals, challenges, and all matters related to its jurisdiction, including conflicts of jurisdiction; ${ }^{349}$ and (6) develop by-laws and the procedures for the discharge of its functions. ${ }^{350}$

337. See Constitution of the Arab Republic of Egypt art. 76, Sept. 11, 1971, as amended, May 22, 1980, May 25, 2005, Mar. 26, 2007; Stilt, supra note 24, at 351.

338. Stilt, supra note 24 , at 363.

339. Law No. 174 of 2005 (Regulating the Presidential Elections), Al-Jarida Al-Rasmiyya, 2 July 2005 , art. 5 (Egypt).

$340 . \quad I d$.

341. Id.

342. Id. The Supreme Court's (Court of Cassation) jurisdiction includes consideration of appeals brought to it from the Court of Appeals by either an adversarial party or public prosecutor and examination of lawsuits that arose from a judge's action. Wahab, supra note $8, \S 6.4$.

343. Law No. 174 of 2005 (Regulating the Presidential Elections), Al-Jarida Al-Rasmiyya, 2 July 2005, art. 5 (Egypt).

344. Id. Article 5 does not specify what qualifications a political must have to be "recognized for their impartiality." Stilt, supra note 24, at 351.

345. See Constitution of the Arab Republic of Egrpt art. 76, Sept. 11, 1971, as amended, May 22, 1980, May 25, 2005, Mar. 26, 2007; Stilt, supra note 24, at 351.

346. Stilt, supra note 24 , at 351 .

347. Law No. 174 of 2005 (Regulating the Presidential Elections), Al-Jarida Al-Rasmiyya, 2 July 2005, art. 8 (Egypt); Stilt, supra note 24 , at 350-51.

348. Stilt, supra note 24 , at 351 .

349. See id.

350. Id. 
As Egypt's 2012 presidential elections neared, the PEC became the target of criticism by various Egyptian stakeholders. ${ }^{351}$ The PEC lacked credibility because political parties selected half of its members via a highly politicized system favoring the dominant party. ${ }^{352}$ Thus, minority parties were structurally disadvantaged by the non-judicial PEC appointees' inevitable loyalty to the majority party. This became the basis for demands to transform the PEC into a fully judicial entity. ${ }^{353}$

\section{G. The Post-Revolution Presidential Elections Law-Law No. 174 of 2005}

The protracted negotiation process for amending parliamentary election laws informed and expedited the process for amending presidential election laws. The SCAF's initial proposed law included many of the same reforms passed for parliamentary elections, including depoliticizing the PEC by making it judicially managed. ${ }^{354}$ Notwithstanding the negotiations between the SCAF and political parties, the SCAF established the rules that dictated the manner and time of the elections as part of the Constitutional Declaration issued on March 30, 2011.355

On January 18, 2012, just five days before the new People's Assembly took office, the SCC declared unconstitutional the SCAF's draft law regulating the 2012 presidential elections. ${ }^{356}$ The Court's objections were largely technical rather than substantive. ${ }^{357}$ In particular, the Court struck down a provision mandating that the chairmanship of the PEC should pass to the president of the Cairo Court of Appeals in the event that the chief justice of the

351. Al-Masry Al-Youm, MP Says Provision Regulating Presidential Election Committee Will Not Be Modified, Ecypt INDEP. (Feb. 22, 2012), http://www.egyptindependent.com/node/ 675941; Stilt, supra note 24, at 363.

352. Stilt, supra note 24 , at 350 .

353. Election Administration, Carnegie Endowment for INT'L Peace, http://egyptelections.carnegieendowment.org/2011/09/27/election-administration (last visited Jan. 9, 2013) (highlighting that opposition figures included judicial supervision of election in their demands).

354. Constrtutional Declaration, supra note 21, art. 28 (listing the judicial figureheads composing the PEC).

355. BASSIOUNI, supra note 133, at 6.

356. Al-Masry Al-Youm, Presidential Election Draft Law Unconstitutional, Says Egyptian Court, EGYPT INDEP. (Jan. 18, 2011), http://www.egyptindependent.com/news/presidential-election-draft-law-unconstitutional-says-egyptian-court.

357. Nathan J. Brown \& Mara Revkin, Egypt's Supreme Court Ruling on the Presidential Election Law: Road Block or Minor Speed Bump for the Military?, Atlantic Council (Jan. 19, 2012), http://www.acus.org/egyptsource/egypt\%E2\%80\%99s-supreme-court-ruling-presidential-election-law-road-block-or-minor-speed-bump-mi. 
SCC steps down as PEC chair. ${ }^{358}$ The Court held that this stipulation violates articles of the March 30 Constitutional Declaration, ${ }^{359}$ which required that the chairmanship transfer to the oldest vice presidents of the Court. ${ }^{360}$ The Court also clarified the eligibility requirements for presidential candidates through an anti-fraud mechanism that required notarization of the 30,000 signatures submitted by a potential presidential candidate. ${ }^{361}$ Moreover, the Court instituted a more restrictive definition of Egyptian citizenship. ${ }^{362}$ Finally, the Court authorized a two-day voting period. ${ }^{363}$

The Court's rejection of the draft law left the SCAF in a race against time to draft and pass a presidential election law that would pass constitutional muster before the first session of parliament commenced on January 23, 2012.364 In fact, the SCAF did just that, and on January 19, 2012, the SCAF issued Decree No. 12 of 2012, which comprehensively amended Egypt's presidential election law.

Most notably, the Decree changes the presidential qualifications and the mechanism for supervising presidential elections. ${ }^{365}$ Postrevolution, a presidential candidate must: (1) be an Egyptian citizen without dual citizenship and have Egyptian parents, neither of which can hold dual citizenship; ${ }^{366}$ (2) complete his or her obligatory military service or receive an exemption certificate; ${ }^{367}$ and (3) receive written endorsement from at least thirty elected members of parliament or a total of 30,000 eligible voters from fifteen governorates. ${ }^{368}$ The 30,000 eligible voters must include at least 1,000 eligible voters from each of the fifteen governorates. ${ }^{369}$ Neither an elected member of parliament nor an eligible voter

358. Id.

359. Constitutional Declaration, supra note 21, art. 28. Referendum mandates the commission to be initially chaired by the president of the SCC. Id. In striking down the provision mandating the chairmanship transfer to the president of the Cairo Court of Appeals, the SCC held that Article 28's mandate implies that the chairmanship should transfer to the next senior most judge of the SCC, not to the president of the Cairo Court of Appeals. Id.

360. Brown \& Revkin, supra note 357.

361. Id.

362. Id.

363. Id.

364. Id.

365. Id.

366. Law No. 174 of 2005 (Regulating the Presidential Elections), Al-jarida Al-Rasmiyya, 2 July 2005, art. 13 (Egypt).

367. Id.

368. Decree Law No. 12 of 2012 (Concerning Amendments to the Presidential Elections Law), art. 2 (Egypt).

369. Id. 
may endorse more than one presidential candidate. ${ }^{370}$ Moreover, a candidate cannot be married to a non-Egyptian and must be at least forty years old. ${ }^{371}$

Alternatively, a political party that obtains a single seat in the People's Assembly or the Shura Council in the most recent elections may nominate a presidential candidate from their party membership. ${ }^{372}$ The changes to the endorsement requirements lower the threshold for becoming a presidential candidate, enabling smaller parties to nominate presidential candidates more easily. Indeed, over five hundred individuals sought a place on the 2012 presidential ballot. ${ }^{373}$

Post-revolution law also imposed a 10 million Egyptian pound limit on campaign budgets to curtail the advantages of wealthy candidates, although the requirement was not fully enforced in the 2011-2012 elections. ${ }^{374}$ In addition, future presidents cannot serve more than two four-year terms and the president is required by law to appoint a vice president within the first month of taking office. $^{375}$ These two provisions are especially salient in Egypt because Mubarak ran for six-year terms indefinitely and refused to appoint a vice president for almost his entire thirty-year tenure. ${ }^{376}$

In addition to providing laxer nomination requirements, Decree No. 12 of 2012 makes significant changes to the composition and function of the PEC. ${ }^{377}$ The Decree removes political appointees from PEC membership, limiting the PEC's composition to the fol-

370. Id.

371. Constitutional Declaration, supra note 21, art. 26.

372. Decree Law No. 12 of 2012 (Concerning Amendments to the Presidential Elections Law), art. 3 (Egypt).

373. Hamza Hendawi, Hundreds Prepare Candidacies as Egypt's Presidential Election Campaign Kicks Off, Global Edmonton (Mar. 14, 2012), http://www.globaltvedmonton.com/ hundreds+prepare+candidacies+as+egypts+presidential+election+campaign+kicks+off/ $6442600717 /$ story.html.

374. Bassiouni, supra note 133, at 6. But see Yang Xin, High Expenses of Election Campaigns, CCTV (May 23, 2012), http://arabic.cntv.cn/program/news_ar/20120523/115137. shtml (noting that all of the presidential candidates violated the ten million Egyptian pound limit on campaign expenses); Yasser Barakat, Illegal Wealth Rules Egypt (May 21, 2012), http://www.elmogaz.com/weekly/26/may/12/30829 (reporting that Shafiq spent over 300 million Egyptian pounds and Morsi spent 250 million Egyptian pounds on the first round of the 2012 presidential elections).

375. See Constitutional Declaration, supra note 21, arts. 77, 139.

376. Peter Kenyon, Egypt's Mubarak: A Cautious, Heavy-Handed Ruler, NPR (Feb. 11, 2011), http://www.npr.org/2011/02/11/133665161/egypts-mubarak-a-cautious-h eavyhanded-ruler (noting Mubarak did not appoint a vice president until January 2011).

377. See Constitutional Declaration, supra note 21, art. 28. 
lowing judges ${ }^{378}$ : (1) the head of the SCC, as chair; (2) the head of the Cairo Court of Appeals; (3) the most senior deputy judge of the SCC; (4) the most senior deputy judge of the Court of Cassation; and (5) the most senior deputy judge of the State Council. ${ }^{379}$ In the event that the head of the SCC is unable to serve as chair, the most senior deputy of the SCC shall replace him or her in this role. ${ }^{380}$ If any member other than the chair is unable to serve on the PEC, the next most senior judge of the same court shall replace that member. ${ }^{381}$

Critics of the PEC had long complained that the political appointments undermined the PEC's independence by giving the ruling party great influence in how the PEC supervised presidential elections and investigated voting irregularities. ${ }^{382}$ Decree No. 12 of 2012 depoliticizes the PEC's membership by eliminating the requirement that the People's Assembly and Shura Council appoint five public figures to the PEC. ${ }^{383}$ The transition to full judicial membership is supposed to strengthen the PEC's ability to carry out its duties without undue influence from political parties.

Despite these constructive developments, Decree No. 12 of 2012 has two major flaws. First, the decree immunizes PEC decisions from appeal because Article 28 of the interim Constitutional Declaration bars the right to appeal a PEC decision, thus vesting the PEC with unchecked authority and no oversight. ${ }^{384}$ Proponents of this

378. Decree Law No. 12 of 2012 (Concerning Amendments to the Presidential Elections Law), art. 5 (Egypt).

379. Constitutional Declaration, supra note 21, art. 28.

380. See Nathan Brown \& Mara Revkin, Egypt's Supreme Court Ruling on the Presidential Election Law: Road Block or Minor Speed Bump for the Military?, Atlantic Council (Jan. 19, 2012), http://www.acus.org/egyptsource/egypt\%E2\%80\%99s-supreme-court-ruling-presidential-election-law-road-block-or-minor-speed-bump-mi; see also Decree Law No. 12 of 2012 (Concerning Amendments to the Presidential Elections Law) (Egypt).

381. See Decree Law No. 12 of 2012 (Concerning Amendments to the Presidential Elections Law) (Egypt).

382. See Int'l Found. for Electoral Sys., Elections in Egypt: Key Challenges for Credible and Competitive Elections 9-10 (2011).

383. Compare Decree Law No. 12 of 2012 (Concerning Amendments to the Presidential Elections Law) (Egypt) (omitting requirement of Shura Council and People's Assembly to appoint members to the PEC), with Law No. 174 of 2005 (Regulating the Presidential Elections), Al-Jarida Al-Rasmiyya, 2 July 2005 (Egypt) (regulating the presidential elections and requiring the Shura Council and the People's Assembly to appoint members of the PEC).

384. Gamal Essam El-Din, Legitimacy of Egypt's Presidential Elections Commission Questioned, Ahram OnLine (Mar. 16, 2012), http://english.ahram.org.eg/NewsContent/1/64/36859/ Egypt/Politics-/-Legitimacy-of-Egypts-presidential-elections-commi.aspx [hereinafter ElDin, Legitimacy]; Gamal Essam El-Din, Idiot's Guide to Egypt's Presidential Elections 2012, AswAT MASRIYA (Mar. 12, 2012), http://en.aswatmasriya.com/news/view.aspx?id= febeea0e-7064-4f5f-b395-acd683b42adc [hereinafter El-Din, Idiot's Guide]. 
rule have argued that a right to appeal would leave the legitimacy of the newly elected president on uncertain grounds and is otherwise unnecessary because the PEC is already comprised of judges from Egypt's highest courts. ${ }^{385}$ Opponents of a judicially-run commission are calling for an independent elections commission similar to those found in North Africa, India, and Ghana. ${ }^{386}$ Meanwhile, even supporters of a judicially-run system challenge the Decree's anti-democratic method (i.e., the SCAF amending a law passed by public referendum). ${ }^{387}$ This argument, however, is belied by the numerous decrees unilaterally passed by the SCAF without any input from the public, much less a parliament. In any event, the point is moot because the new constitution replaces the PEC with a new body that is subject to regulation by the parliament. ${ }^{388}$

The absence of independent oversight of PEC decisions risks a repeat of past abuses of authority, even given the replacement of PEC's political appointees with judicial appointees. Although Egyptians trust the judiciary, the process remains structurally flawed and prone to politicization, particularly if the judiciary lacks independence. ${ }^{389}$ Indeed, the presiding head of the SCC at the time, Farouk Sultan, was perceived by some Egyptians as loyal to the Mubarak regime. ${ }^{390}$ Specifically, Sultan was suspected of rigging the past elections of the Lawyers' Syndicate to prevent Islamists from winning. ${ }^{391}$ Prior to Sultan, Mubarak had appointed

385. El-Din, Idiot's Guide, supra note 384 (quoting PEC's Farouk Sultan as justifying the no appeals rule by saying: "This immunity is necessary because members of HEC represent the highest judicial authorities in Egypt and also because opening the door to filing appeals leaves the legitimacy of the newly-elected president on shaky grounds").

386. KHALIL ET AL., supra note 100 , at 15 (recommending that all administrative decrees, including decrees from the PEC, be subject to judicial review).

387. El-Din, Legitimacy, supra note 384.

388. See Constitution of the Arab Republic of Egypt arts. 208, 228, 26 Dec. 2012, translated by Nivien Saleh, The 2012 Constitution of Egypt, Translated by Nivien Saleh, with Index, NIVIEN SALEH, http://niviensaleh.info/constitution-egypt-2012-translation (last visited Feb. 12, 2013) (unofficial translation).

389. See Chazli \& Chazu, supra note 19 (highlighting the numerous ways in which Egypt's judiciary is vulnerable to improper interference by the executive branch); see also Egypt: Widespread Military Torture of Protestors Arrested in May, Hum. RTs. Watch (May 19, 2012), http://www.hrw.org/news/2012/05/19/egypt-widespread-military-torture-protesters-arrested-may [hereinafter Widespread Military Torture of Protestors] (reporting the judiciary's failure to act on violent, arbitrary, and unlawful military action against protestors).

390. Kareem Fahim, Turmoil in Egypt Race Puts Spotlight on Panel's Motives, N.Y. TIMES (Apr. 19, 2012), http://www.nytimes.com/2012/04/20/world/middleeast/turmoil-inegypt-elections-puts-spotlight-on-panels-motives.html; see also KHALIL ET AL., supra note 100, at 15 (recommending a restriction on the president's discretionary power to appoint the chief justice of the SCC as a means of bolstering the independence of the judiciary).

391. El-Din, Legitimacy, supra note 384. 
Fathi Nagib in 2001, Mamduh Mara'i in 2003, and Prosecutor General Maher 'Abd al-Wahed in 2006 as the SCC's chief justice, all of whom had demonstrated their loyalty to the Mubarak regime during their careers in the Ministry of Justice. ${ }^{392}$

In response to reformers' demands and presumably behind the scenes lobbying by the judiciary, the military in June 2011 issued a decree that restricts the president's choices for the position of chief justice of the SCC to the Court's three most senior members and requires the agreement of the General Assembly of the Court's justices for the appointment to proceed. ${ }^{393}$ Despite this reform, the SCC has faced political pressure from the parliament to reverse its disqualification of ten presidential candidates. ${ }^{394}$ Should such incidents become the norm, the judiciary's independence will be in jeopardy. Therefore, an independent elections commission, instead of a judicial body, may be a better option that permits de novo judicial review and avoids ensnaring the judiciary in election disputes. ${ }^{395}$

The significant legitimacy deficit surrounding past presidential elections warrants reforms that ensure a fair and neutral elections oversight process. Because the PEC has exclusive authority to monitor all stages of the election, ranging from the registration process to the counting of votes and announcing the results, an independent appeal process is essential. ${ }^{396}$ The next few presidential elections will determine if Egypt can shed its authoritarian history and permit the people to peacefully remove an unpopular or incompe-

392. Moustafa, supra note 64 , at 198-99, 205, 216.

393. Brown, supra note 119.

394. Dina Ezzat, The Final Countdown, Al-Ahram Weekly Online (May 10-16, 2012), http://weekly.ahram.org.eg/2012/1097/frl.htm.

395. But see Fahim, supra note 390 (noting how currently the election commission has broad powers to oversee the election with little to no oversight).

396. See id. (noting the populace's distrust of the current system and the lack of available review). In light of the Muslim Brotherhood's sweeping victory in the post-revolution parliamentary elections, Egyptians are rightfully wary of abuses committed by any new dominant party. Results of Egypt's People's Assembly Election, supra note 189. The Muslim Brotherhood's Freedom and Justice Party and the Salafi al-Nour Party collectively secured 356 seats, or $71.47 \%$, of the total 498 elected seats in the People's Assembly. Id. Similarly, these two parties combined won 150 seats, or $83.3 \%$, of the total 180 elected seats in the Shura Council. Results of Shura Council Elections, Carnegie Endowment for Int'L Peace (Feb. 29, 2012), http://egyptelections.carnegicendowment.org/2012/02/29/results-ofshura-council-elections. Thus, for opposition parties to nominate a presidential candidate, they will need the endorsement of the Freedom and Justice Party or the Al-Nour Party. Law No. 174 of 2005 (Law on Regulating the Presidential Elections), Al-jarida Al-Rasmiyya, 2 July 2005, art. 2 (Egypt) (mandating that presidential candidates need 250 written endorsements-at least sixty-five from the People's Assembly and twenty-five from the Shura Council-to be an eligible candidate). 
tent president-making the legitimacy and efficacy of the PEC all the more important.

\section{The Gase for Election Reforms in Egypt}

While post-revolution amendments to election laws improve transparency and independent oversight of Egypt's electoral system, additional legislative improvements are needed to establish a fair, free, and accessible electoral process for all Egyptians. In particular, women and Copts are currently unlikely to attain representation in parliament in proportion to their percentage of the population. Historic biases coupled with structural impediments to elected office warrant remedial programs to ensure adequate representation of women's diverse interests. ${ }^{397}$ As women's participation in electoral politics normalizes over time, remedial measures such as quotas or gender ordering on party lists can be phased out. Moreover, the increasing calls for political interference with the judicially-run PEC warrant creation of an independent elections commission whose decisions are subject to judicial review. This common international practice preserves the independence of the judiciary while preventing the executive branch from corrupting the elections process.

The following sections examine the shortcomings of election laws insofar as they adversely impact women and Egyptian Copts, hinder transparency, compromise the independence of the judiciary, and create electoral uncertainties that engender political instability. Section A examines election laws' failure to meaningfully broaden access to political office beyond a class of elite and politically connected Muslim males. Section B analyzes the adverse impact of the abolition of the sixty-four-member quota for female representation in parliament and discusses whether a similar quota is needed for Coptic candidates. Sections $\mathrm{C}$ highlights additional shortcomings of the recent reforms by focusing on the reforms' failure to mandate that the HEC implement transparent procedures for promulgating electoral rules and tallying votes.

397. See, e.g., Egyptian Ctr. for Women's Rights, In 2012 Parlament. . What Women LOST AND WHAT EGYPT LosT?! 1 (2012) (noting that Egypt is ranked 121 out of 134 countries in gender disparities in economic participation, among other indicators of gender empowerment). 


\section{A. Inadequate Representation of Women and Coptics in Parliament}

Historically, Egypt has failed to meaningfully include women and Copts in political life. ${ }^{398}$ After decades of international advocacy calling for more female representation in parliament, ${ }^{399}$ as well as a UN recommendation that nations take special measures to increase women's representation in public life ${ }^{400}$ the Mubarak government relented in 2010 and mandated a quota for sixty-four women to serve in the People's Assembly. ${ }^{401}$ While a quota is not a flawless option for increasing women's representation, it facilitates normalization of female participation in elected office until such time that intervention is no longer needed to produce proportional representation of women. ${ }^{402}$

Soon after taking control of the executive branch in 2011, the SCAF eliminated the female quota, which resulted in a dismally low number of women in the 2012 People's Assembly. ${ }^{403}$ Political parties exacerbated this regression in gender rights through a refusal to list female candidates at the top of their party lists, which nearly guaranteed women's exclusion from parliament. ${ }^{404}$ Many women, therefore, view the 2011 election results as a betrayal of Egyptian women's significant sacrifices in the January 25 Revolution. ${ }^{405}$

398. Julie Tomlin, Egypt Election: No Revolution for Women, Guardian (Dec. 1, 2011), http://www.guardian.co.uk/world/2011/dec/01/egypt-revolution-women-elections.

399. See generally Convention on the Elimination of All Forms of Discrimination against Women, supra note 37. Egypt became a signatory party to CEDAW on July 16, 1980. Id.

400. "[The CEDAW] [r]ecommends that States Parties make more use of temporary special measures such as positive action, preferential treatment or quota systems to advance women's integration into education, the economy, politics and employment." Int'l Human Rights Instruments, Compilation of General Comments and General Recommendations Adopted by Human Rights Treaty Bodies, General Recommendation No. 5, U.N. Doc. HRI/GEN/1/Rev.9 (Vol. II) (May 27, 2008).

401. See Evan Hill, Women Make Leap in Egypt Parliament, Al Jazeera (Nov. 29, 2010), http://www.aljazeera.com/news/middleeast/2010/11/2010111813029420433.html. But see Aili Mari Tripp, Do Arab Women Need Electoral Quotas, Foreign Policy (Jan. 19, 2012), http://mideast.foreignpolicy.com/posts/2012/01/19/do_arab_women_need_electoral_ quotas (noting how Egypt has since done away with its quota law altogether).

402. Beydoun, supra note 35, at 74; see also Tripp, supra note 401.

403. Beydoun, supra note 35, at 73; Trudy Rubin, Egyptian Women Fighting for Rights, Phicly.Com (June 11, 2012), http://articles.philly.com/2012-06-11/news/32157062_1_ ahmed-shafik-egyptian-women-head-scarf (noting that women only occupied $2 \%$ of the seats parliament after the quota-less election in fall 2011).

404. Beydoun, supra note 35, at 99; Rubin, supra note 403 (noting that nearly all parties put female candidates low on their lists).

405. Garcia-Navarro, supra note 256 (quoting female youth activist Dalia Ziada, "It really hurts so much when the same people you were within that square that day, who fighting against the regime ... are now turning against you. It's like betrayal, betrayal from our companions."); Egypt Women's March Attacked on Tahrir Square, AFP (June 8, 2012), http://www.google.com/hostednews/afp/article/ALeqM5iNe-ZYNym0eZXOulh9mvGgF 
Despite the millions of women who protested beside their male compatriots, only twelve women are in the People's Assembly and five in the Shura Council in 2012.406

For Egypt's Coptic minority, proportional representation is particularly problematic because of their geographic concentration in a few districts. ${ }^{407}$ Coptic candidates may be able to win some seats in Cairo, Upper Egypt, and Alexandria, where they constitute a critical mass of the population. ${ }^{408}$ However, in areas where Copts are not concentrated, they are unlikely to be nominated to a party's list. Even when they do manage to appear on a party's list, they will join women at the bottom. ${ }^{409}$ As a result, their representation in the parliament is not proportional to their percentage in the population. ${ }^{410}$

\section{Proactive Measures Are Necessary to Ensure Gender Parity in Politics}

Other countries' experiences suggest that a proportional representation system is best suited for promoting election of female

WoRCA?docId=CNG.995fdb44bf33365f355136a6af69b2c9.221 (reporting that women faced and still face sexual and physical assaults as a result of participating in protesting); Rubin, supra note 403 (noting that military brutalized peaceful female demonstrators and forced them to take virginity tests). "On Jan. 25, me and my mother and sisters convinced my father and brothers to join us .... . We women stood at the forefront of the security barriers so the men could pass behind us .... We broke the security barriers till we got to Tahrir Square," said Sondos Asem, editor of the Muslim Brotherhood's English-language site. Josh Dzieza, 'After the Arab Spring, Are Egypt's Women Losing Ground?, DaILY BEAST (Mar. 9, 2012), http://www.thedailybeast.com/articles/2012/03/09/after-the-arab-spring-areegypt-s-women-losing-ground.html.

406. Results of Egypt's People's Assembly Election, supra note 189. Two of the twelve women were appointed to the People's Assembly: Maryann Malaak Kemaal and Suzy Adly Nashed. Egypt's Military Leader Directly Appoints Five Copts to Parliament, Assyrian InT'L News AgenCy (Jan. 22, 2012), http://www.aina.org/news/20120122123929.htm; see also, e.g., Press Release, Carter Ctr., Preliminary Statement, supra note 205 (noting that only five women were elected to the Shura Council); Widespread Military Torture of Protestors, supra note 389 (offering victims' direct accounts of the military's arbitrary, unjustified arrests, beatings, and torturing of female protestors following the early May 4, 2012, protest near the Defense Ministry, including testimony of whipping, electroshocking, and physical beating).

407. Mohammad Abu Dahab, Gharbia Copts Reluctant to Run in Elections, Egrpt Votes (Jan. 11, 2012), www.egyptvotes.org/en/politics/item/430-gharbia-copts-reluctant-to-runin-elections.html.

408. Results of Egypt's People's Assembly Election, supra note 189.

409. See Dahab, supra note 407 (finding in the Gharbia governorate only five Copt candidates for parliamentary elections out of a total of 521 candidates).

410. Copts make up approximately $10 \%$ of Egypt's population but they represent less than $2 \%$ of members of parliament. Abdel Rahman Youssef, Egyptian Copts: It's All in the Numbers, AL-AkHBar EnGLiSH (Sept. 30, 3012), http://english.al-akhbar.com/node/12728; see also infra notes 463-470 and accompanying text. 
and ethnic minority candidates. ${ }^{411}$ Female representation in parliaments is approximately twice as high in countries with proportional representation electoral systems than in countries that use majority or plurality electoral systems. ${ }^{412}$ However, Egyptian political parties' refusal to include female candidates at the top of their party lists, despite initial promises to do so, ${ }^{413}$ evinced that more affirmative measures are needed. In order for Egypt to adequately recognize Egyptian women's contributions to the nation, the government should either reinstate its previous female candidate quota or follow a model used by Tunisia that mandates as a matter of law that every other candidate be a woman on political party lists. ${ }^{414}$ Absent such measures, Egyptian women will continue to be denied their rightful place in government despite their substantial contribution to the January 25 Revolution and society at large. ${ }^{415}$

Despite attaining suffrage in 1956, Egyptian women have not been sufficiently represented in parliament. ${ }^{416}$ The Mubarak regime established the female candidate quota in 2010, which increased the percentage of females in the People's Assembly from $8 \%$ in $2007^{417}$ to $12.70 \%$ in 2010.418 The quota system was in effect for only two legislative terms, or ten years, and some viewed the system as an attempt to change deep-seated popular views opposing women serving in elected office. ${ }^{419}$

Employing quotas to increase women or minority representation in public life is a subject of contention among academics and policymakers. While the underlying theories on the efficacy of gender quotas are not the focus of this Article, it is worth highlighting the key arguments in favor and against the use of gender quotas. Proponents argue that quotas are not preferential treatment or positive discrimination, but rather affirmative action and

411. Karen Bird, The Political Representation of Women and Ethnic Minorities in Established Democracies: A Framework for Comparative Research 17 (Acad. for Migration Studies in Den., Working Paper Series, 2004); see also Tripp, supra note 402.

412. Dahlerup \& Freidenvall, supra note 220, at 10.

413. Egyptian CTr. for Women's Rights, supra note 397 (reporting Egyptian political parties' broken promises to support a requirement that at least one woman be listed at the top of each party list).

414. Tripp, supra note 401; see also Beydoun, supra note 35, at 66 (finding Tunisia has the highest percentage of female participation in the Arab region).

415. See Rubin, supra note 403 (quoting the president of Egypt's National Council for W'omen, who observed that parliament must be monitored to ensure they do not make further attempts to revoke rights for women).

416. Analysis of the 2011 Parliamentary Electoral. System, supra note 76, at 10.

417. See id.

418. Elections Held in 2010, supra note 127.

419. ANalysis of the 2011 Parliamentary Electoral System, supra note 76, at 10. 
attempts to remedy inequities produced by deep-rooted privilege and to achieve justice.420 Proponents highlight the distinction between "equal opportunities" and "equality of results." 421 While equal opportunity may offer women the legal right to fully participate in the electoral process, it does not necessarily follow that Egypt will achieve equality of results just because representation of women is demanded or expected. ${ }^{422}$

Meanwhile, opponents of quotas start from the position that political representation is about the representation of ideas and interests, not gender or the representation of social groups. ${ }^{423}$ Of course, this assumes that the interests of men and women in society do not diverge according to their different social status and experiences. Those opposed to quotas argue they contradict the principle of equal opportunity and equal treatment because women are given priority over men. ${ }^{424}$ Thus, quotas become discriminatory as one group of candidates is favored at the expense of better-qualified candidates. ${ }^{425}$ The common response to this critique is to highlight the disparities in treatment, social status, and opportunities for women that contribute towards a candidate's qualifications. ${ }^{426}$ Hence, failing to take affirmative measures perpetuates the underlying disparities that prevent women from winning without such measures. Some critics also point out that affirmative measures such as quotas cast a suspicion on all women who have attained positions of power that their success is due to special treat-

420. Dahlerup \& Freidenvall, supra note 220, at 20.

421. Drude Dahlerup, Quotas - A Jump to Equality? The Need for International Comparisons of the Use of Electoral Quotas to Obtain Equal Political Citizenship FOR WOMEN 4 (2002). Proponents have proffered four primary arguments in support of women's equal representation in governance. Id. The "justice argument" takes the position that women represent half of the population and thus have the right to half the seats. Id. The "experience argument" contends that women have different experiences (either biologically or socially constructed) that ought to be represented in government. Id. The "interest group argument" accepts that women and men have partly conflicting interests and thus men cannot adequately represent women. Id. Finally, the "role model argument" focuses on the utility of women politicians serving as role models to pave the way for other women to serve in government. Id. Moreover, proponents argue quotas do not discriminate, but rather compensate for existing barriers that hinder women from receiving their fair share of political seats as well as prevent further barriers and mechanisms of exclusion. Id. In the end, proponents believe that quotas offer an effective mechanism to integrate women into all facets of society so long as they are thoughtfully implemented and perceived as legitimate by the electorate. Id.

422. Id.

423. Dahlerup \& Freidenvall, supra note 220, at 104.

424. Id. at 20 .

425. Id. at 18 .

426. Dahlerup, supra note 421 , at 2. 
ment instead of competency. ${ }^{427}$ Finally, there is the slippery slope argument that warns of demands for quotas by other groups thereby resulting in the balkanization of politics based on group interests. ${ }^{428}$ The glaring flaw in this argument is that special interest politics already occurs independent of quotas for reasons unrelated to gender inequities.

In Egypt, opponents of quotas prevailed. In July 2011, the SCAF revoked the quota, leaving little incentive for political parties to nominate female candidates. ${ }^{429}$ Instead, the law requires political parties participating in proportional representation districts to include at least one female candidate anywhere on their party lists. ${ }^{430}$ Parties consistently place women at the bottom of their list. 431 Electoral districts that are often too small to allow more than one or two parties to win more than one or two seats per district exacerbate the dim election prospects for female candidates. ${ }^{432}$

Tunisia's experience offers valuable insights into another potential method for expanding female political representation in parliament. 433 Tunisia's post-revolution caretaker government crafted an innovative system to ensure women were represented in the new Tunisian parliament. 434 Candidates for 217 seats divided among thirty-three districts ran as members of party lists under a proportional representation system. ${ }^{435}$ The electoral rules mandated that every other candidate on a party list be a woman. ${ }^{436}$ Despite these

427. Dahlerup \& Freidenvall, supra note 220 , at 18 (explaining the argument that women candidates are less qualified than their male competitors and should not be ushered into office simply because they are women).

428. Id. at 19.

429. See Male-Dominated Parliament Wories Experts, Candidates, Daily News Egypt (Dec. 7, 2011), http://dailynewsegypt.com/2011/12/07/male-dominated-parliament-worriesexperts-candidates (quoting Maya Morsy, U.N. Women Country Coordinator, as saying: "Many factors hinder women's political participation, such as political parties being slow to respond to women's interest, under-investment in women's campaigns and cultural barriers."); see also Beydoun, supra note 35, at 73.

430. BASSIOUNI, supra note 133 , at 16 (reporting the SCAF's abolition of the women's quota requirement).

431. Rubin, supra note 403.

432. See Egypt's Election Primer, supra note 324; Results of Egypt's People's Assembly Election, supra note 189 (reporting that no women won seats in individual member district races).

433. Tunisia Election Raises Hope for Arab Women and Democracy: Vietv, Bloomberc (Oct. 26, 2011), http://www.bloomberg.com/news/2011-10-26/view-tunisia-election-raiseshopes-for-arab-women-democracy.html.

434. Id:; Beydoun, supra note 35, at 66 .

435. Tunisia Election Raises Hope for Arab Women and Democracy: View, supra note 433.

436. Daphne McCurdy, Project on Middle E. Democracy, A Guide to the Tunisian ELECTIONS 3-4 (2011). 
remedial measures, in 2011 only forty-nine women $(22.5 \%)$ were elected to Tunisia's 217-member National Constituent Assembly, which was the body tasked with creating a new Tunisian constitution after President Zine El Abidine Ben Ali was deposed. ${ }^{437}$ These disproportionately low numbers were a result of parties consistently listing women second in districts where only one seat was available, thereby guaranteeing only the male candidate a seat upon the party's victory. 438

Political parties in Egypt oppose a gender ordering mandate similar to Tunisia's because their success derives from the popularity of their male candidates. ${ }^{439}$ In smaller districts where parties tend to win no more than one or two seats, any perceived external interference with the formulation of the party list will be met with strong opposition by the predominantly male party leadership. A gender ordering mandate would also add an additional layer of complexity to an already complicated electoral system that imposes occupational requirements on each district through a mix of proportional representation and independent candidates. ${ }^{440}$ Notwithstanding these challenges, women should not collectively bear the burden of entrenched male interests. ${ }^{441}$ Requiring alternating

437. Duncan Pickard, How Well Did Women Really Fare in Tunisia's Elections?, POWER \& PoL'y (Dec. 6, 2011), http://www.powerandpolicy.com/2011/12/06/how-well-did-womenreally-fare-in-tunisia\%E2\%80\%99s-elections. Forty-two of the forty-nine women are from the El-Nahhda Party, Tunisia's largest Islamist party, which won $47 \%$ of all National Constitutional Assembly seats. Eileen Byrne, The Women MPS Tipped to Play Leading Roles in Tunisia's New Assembly, Guardian (Oct. 28, 2011), http://www.guardian.co.uk/world/2011/ oct/29/women-mps-tunisia-government; Lessons from Constitution Making in Tunisia, AtLANTIC Council. (Dec. 13, 2012), http://www.acus.org/event/lessons-constitution-makingtunisia.

438. MCCuRdy, supra note 436, at 3-4 (explaining political parties' strategic manipulation of candidate list gender requirements by listing male candidates in the top position where only winning one seat was expected). The strategic ordering of candidates ensured that a man would likely be the only winner from that party's candidate list in that district, putting female candidates at a disadvantage. Id.; see also Eymen Gamha, The Candidates: Heads of Lists by Party and District, Tunisia Lrve (Oct. 5, 2011), http://www.tunisia-live.net/ 2011/10/05/head-of-lists.

439. See Tunisia Election Raises Hope for Arab Women and Democracy: View, supra note 433; see also Islamist, Liberal Parties Fielded Few Female Candidates, Says Report, Daily News Egypt (Feb. 1, 2012), http://www.dailynewsegypt.com/2012/02/01/islamist-liberal-partiesfielded-few-female-candidates-says-report/.

440. See supra Part III.B (providing a detailed description of the occupational requirements in Egypt's electoral system).

441. See Beydoun, supra note 35, at 64-65 ("Arab women remain effectively disenfranchised from the salient processes that shape governance in their respective states.... If we consider political representation as a form of empowerment, a historical survey of the compositions of Arab parliaments reveals that women have had little or no place in the most vital political institutions of their home state.") As one well-known Egyptian woman activist stated, "Egypt needs equality. . this is the main problem that the new constitution 
women on party lists would be a minor burden compared to the significant sacrifices made by Egyptian women both during the January 25 Revolution and in its aftermath. ${ }^{442}$

Given the political hurdles inherent in implementing Tunisia's gender ordering model, perhaps the most practical option for Egypt is to reinstate the 2010 quota for female candidates for the next parliamentary elections. ${ }^{443}$ That quota provision called for the expansion of the People's Assembly to include sixty-four new seats for female candidates. ${ }^{444}$ The law created two new seats for women in twenty-six out of Egypt's then twenty-nine governorates. $^{445}$ Female candidates were elected through a simple majority vote and the occupational requirement did not apply. ${ }^{446}$ This system led to a $1500 \%$ increase in the number of female par-

must address, whether that's between men and women or Muslim or Christians, regardless of social status." Bel Trew, Egyptian Women Demand Representation at Parliament Gates, AL. BAWABA (Mar. 10, 2012), http://albawaba.com/editorchoice/egyptian-women-demandrepresentation-parliament-gates-416222 (quoting Dr. Laila Soueif).

442. One scholar has aptly framed the nature of such efforts used to achieve gender equality as follows:

The fast track model implies a shift from one concept of equality to another .... [Where] the classic liberal notion of equality stressed 'equal opportunity' or 'competitive equality,' [fast track] quotas represent a shift towards 'equality of results.' According to the former concept, the removal of formal barriers for women's political participation, such as providing women voting rights, was considered sufficient. It was then up to individual women to act . . . Equal opportunity does not exist just due to the removal of formal barriers, it is argued. Direct discrimination and a complex pattern of hidden barriers prevent women from attainting a fair share of political power and influence. Quotas and other measures aiming at an increased level of women's political participation are this regarded as means towards equality of results. Equality as a goal cannot be reached by formal equal treatment solely as a means. If barriers exist, compensatory measures must be introduced as a means to reach equality of result. In this perspective, quotas are not regarded as discrimination (of men), but as a compensation for structural barriers that women face in the electoral process. Thus, quotas as a fast track do not only challenge the Scandinavian model of women's representation, it also questions the concept of equal opportunity by providing the concept of equality with new significance and implications.

Beydoun, supra note 35, at 72.

443. See, e.g., Press Release, Carter Ctr., Preliminary Statement, supra note 205.

444. Bureau of Democracy, Human Rights, \& Labor, 2010 Human Rights Report: Egypt, U.S. Dep't State (Apr. 8, 2011), http://www.state.gov/j/drl/rls/hrrpt/2010/nea/154460. htm.

445. Evan Hill, Women Make Leap in Egyptian Parliament, Al JAZEERA (Nov. 29, 2010), http://www.aljazeera.com/news/middleeast/2010/11/2010111813029420433.html.

446. In 2011, the governorates of "6th of October" and "Helwan" were merged into the governorates of Giza and Cairo, respectively, resulting in twenty-seven total governorates. See Egypt's PM Centralises Helwan and 6 October Governorates, Ahram Online (Apr. 14, 2011), http://english.ahram.org.eg/NewsContent/1/0/10037/Egypt/Egypts-PM-centralisesHelwan-and-October-governor.aspx. 
liamentarians from a mere four female members in 2005 to sixtyfour in 2010.447

Retroactively applying the female candidate quota is impracticable, as members of the People's Assembly were recently elected and took office on January $23,2012 .{ }^{448}$ Thus, a female quota could not realistically be imposed until the next elections in 2016, unless the People's Assembly is expanded to accommodate the quota. Expanding a 508-member lower house to 572, however, risks creating an unwieldy chamber whose large size might inhibit its ability to govern. ${ }^{449}$ As an interim, mitigating measure, the president could be legally mandated to appoint women to all of the ten presidentially appointed positions in the People's Assembly. ${ }^{450}$ While this would not bring women's political representation to its prerevolutionary numbers, it would add ten more members to the dismally low number of women elected to the People's Assembly. ${ }^{451}$

Until the election of women is normalized as part of the Egyptian political experience, remedial measures are necessary to overcome entrenched biases against women serving in political office. $^{452}$ Irrespective of the remedial measure adopted-gender ordering or a quota-Egyptian women deserve to be adequately represented in both houses of parliament. ${ }^{453}$ To deny Egyptian women the right to fully participate in shaping the new Egypt is a denial of their significant contributions to Egyptian society and a recipe for second-class citizenship.

447. Hill, supra note 445 .

448. Jack Shenker, Egyptian Parliament Sworn in Under Heavy Weight of Expectation, GUARDIAN (Jan. 23, 2012), http://www.guardian.co.uk/world/2012/jan/23/egyptian-parliament-sworn-in-expectation.

449. The threat of political paralysis due to parliament's size is well-documented. For example, in the 543-member lower house of India's parliament, known as Lok Sabha, political paralysis frequently occurs, in part due to the body's sheer size. Election Watch, CNN (Feb. 23, 2000), http://articles.cnn.com/2000-02-23/world/election.watch_asiapcf_ india2_1_election-state-assemblies-fiveyear-terms (reporting 545 seats in the Lok Sabha); see also Samanth Subramanian, The Long View: Parliamentary Paralysis, N.Y. Times (Dec. 12, 2011), http://india.blogs.nytimes.com/2011/12/12/the-long-view-parliamentary-paralysis/. In 2011, Lok Sabha passed only fifty-seven out of 200 bills and met just sixty-five days of the year. See Subramanian, supra.

450. The president of the republic has the power to appoint ten members to the People's Assembly. Legal Research Guide: Egypt, LiBr. Congress (July 26, 2012), http://www.loc. gov/law/help/egypt.php.

451. Garcia-Navarro, supra note 256.

452. Beydoun, supra note 35, at 71-72; see also Kochan, supra note 33, at 919.

453. "'Women have virtually no representation in parliament, we need to make sure we are at least half in the constituent assembly, lamented Ghada Shahbender of the Egyptian Organization of Human Rights." Trew, supra note 441. 


\section{Ensuring Proportional Egyptian Coptic Christian Representation in Parliament}

Although Copts make up approximately $10 \%$ of the Egyptian population, their representation in parliament has declined significantly in recent decades. ${ }^{454}$ Coptic representation in parliament peaked in 1942, when Copts comprised $10 \%$ of members of parliament, many of whom belonged to the secular Al-Wafd Party. ${ }^{455}$ Since then, Coptic representation in parliament has gradually declined. ${ }^{456}$

The downward trend began with an official ban in 1953 of all political parties, including the Al-Wafd Party, as part of a series of political reforms under President Nasser's Arab socialist agenda. ${ }^{457}$ These reforms implemented socialist policies while promoting Egypt's Arab character and role as leader of the Arab World.458 Institutional efforts to promote Egypt's Arab heritage marginalized Copts, many of whom identified as Egyptians rather than Arabs. ${ }^{459}$ Although the ban on political parties was officially lifted in 1976, Coptic representation in parliament continued to decline following the adoption of a winner-take-all, independent candidate system in 1990.460 The winner-take-all system disadvantaged minority candidates, who previously only had to win a predetermined minimum number of votes to secure a parliamentary seat under a proportional representation system. ${ }^{461}$ This change, coupled with growing public disillusionment with the government by both Muslims and Copts, further limited Coptic representation. ${ }^{462}$

In 2005, Copts held just $1.5 \%$ of seats (approximately half of which were awarded via presidential appointment) in the People's Assembly and $2.2 \%$ of seats (all of which were appointed) in the

454. Egypt Christians Reject Quota Parliament Seats, Al-Arabiya News (Nov. 21, 2010), http://www.alarabiya.net/articles/2010/11/21/126824.html.

455. See Azmi Bishara et al., Doha Inst., Can We Speak of a "Coptic Question" in

Egrpt? 10, 14 (2011); see also Egypt Christians Reject Quota Parliament Seats, supra note 454.

456. Bishara ET AL., supra note 455 , at $14-15$.

457. Lippman, supra note 148.

458. See Gabriel R. Warburg, Islam and Politics in Egypt: 1952-1980, 18 MiddLE E. STUd. 131,140 (1982).

459. See Bishara et Al., supra note 455 , at 7.

460. See John Ehab, Egypt's Copts Frustrated by Under-Representation in Parliament Polls, EGYPT INDEP. (Nov. 25, 2010), http://www.egyptindependent.com/news/egypts-copts-frustrated-under-representation-parliament-polls.

461. Dunne, supra note 51 , at $4,8,13$.

462. MUSTAFA ET AL., supra note 222, at 79 (noting that when minority groups perceive a type of persecution they tend to withdraw from society). 
Shura Council. ${ }^{463}$ Low Coptic representation in parliament can be attributed in part to political parties' unwillingness to nominate Egyptian Coptic candidates. 464 In the 2005 People's Assembly elections, for example, the then-ruling NDP nominated only two Copts from its list of 444 total candidates. ${ }^{465}$ In 2010, the NDP's list of 839 candidates included only ten Copts. ${ }^{466}$ Out of a total of 5,725 candidates running for election, just eighty-one-less than $2 \%-$ were Copts. ${ }^{467}$ Approximately twenty-four Copts ran as opposition candidates and a number of others as independents, with only two winning a seat. ${ }^{468}$ Due to the abysmally low representation of Copts, debates ensued on whether the government should adopt a quota for Coptic candidates similar to the one for women. 469 While some Egyptians argue a quota would be a useful and necessary corrective measure to ensure greater Coptic representation in parliament, prominent Copts, including the Pope Shenouda III, rejected the idea out of concern it would trigger religious sectarianism in Egypt. ${ }^{470}$

Adoption of the proportional representation system increased Coptic representation in the post-revolution parliament. ${ }^{471}$ In theory, a proportional representation system increases the prospects of small parties and minority groups in gaining representation in

463. Analysis of the 2011 Parlamentary Electoral System, supra note 76, at 11.

464. Joseph Mayton, In Egypt's New Democracy, Copts Feel Sidelined, Persecution.orG (Nov. 17, 2011), http://www.persecution.org/2011/11/19/in-egypt's-new-democracycopts-feel-sidelined (noting that opposition from Islamists, fears by the church establishment of delving too deeply into politics, and growing pessimism among Copts have all contributed to little and low Copt representation on party ballots); see also ANALYSIS OF THE 2011 Parliamentary Electoral System, supra note 76, at 11.

465. Analysis of the 2011 Parlamentary Electoral System, supra note 76, at 11.

466. Amr Hamzawy \& Michele Dunne, The Egyptian Parliamentary Elections: Facts and Figures, CARNEGIE ENDOWMENT FOR INr'L PEACE, http://egyptelections.carnegieendowment.org/2010/11/28/the-egyptian-parliamentary-elections-facts-and-figures (last visited Jan. 9, 2013). Among the twenty-four Copts from opposition parties, five were from $\mathrm{Al}$ Wafd Party, three from Al-Tagammu Party, and four from Al-Ghad Party. Id.

467. Yasmine El-Rashidi, Egypt Elections Obliterate Coptic Voice, AHRAM Online (Dec. 5, 2010), http://english.ahram.org.eg/NewsContent/1/5/1209/Egypt/Egypt-Elections-/ Egypt-elections-obliterate-Coptic-voice.aspx.

468. $I d$.

469. Analysis of the 2011 Parlamentary Electoral System, supra note 76, at 11.

470. Egypt Christians Reject Quota Parliament Seats, supra note 454; Majdi Fikri, NGO Director: I Called for Parliamentary Quota for Copts, ARAB W. REP. (Oct. 6, 2011), http://www. arabwestreport.info/year-2011/week-40/52-ngo-director-i-called-parliamentary-quotacopts.

471. Analysis of the 2011 Parliamentary Electoral System, supra note 76, at 11 (addressing the increase in the number of Copts in parliament from two in 2005 to ten in 2010). 
parliament. ${ }^{472}$ Electoral districts in proportional representation systems are always larger than under a winner-take-all system and fixed according to historical considerations such as traditional geographic boundaries, demographics, and tribal areas. ${ }^{473}$ This promotes greater political participation by minorities because they need not win a majority of the votes in order to win a parliamentary seat. Instead, smaller political parties need only obtain a predetermined minimum number of votes, known as a "baseline." 474 In the case of Copts, multi-member districts increase the chances of election of Coptic candidates in governorates like Minya, Qena, Sohag, and Assiut, where large concentrations of Copts reside. ${ }^{475}$

Egypt's mixed proportional representation and independent candidate system, however, may stunt the possibility for increased minority representation in Egypt's electoral system. The independent candidate system is an American style winner-take-all system where only the highest vote-getter receives a parliamentary seat. ${ }^{476}$ Egypt's mixed system, known as the "German model," combines the close ties enjoyed between representatives and constituents in a winner-take-all system with the fairness and diversity of representation under a proportional representation system. ${ }^{477}$

The absence of a vibrant political environment before the January 25 Revolution favored wealthy businessmen and former NDP members in parliamentary elections. Indeed, in tribal areas, such

472. Douglas J. Amy, Behind the Ballot Box: A Citizen's Guide to Voting Systems $70,72(2000)$.

473. Electoral Systems that Delimit Electoral Districts, ACE Project, http://aceproject.org/ ace-en/topics/bd/bda/bda01/onePage (last visited Jan. 9, 2013) (noting that under plurality and majority systems, minority political parties whose supporters are not geographically concentrated usually obtain fewer seats than their proportion of the vote would suggest they are entitled).

474. See supra Part III.E for more information about the different formulas used for determining the "quota" or "baseline" that each party must obtain to win a parliamentary seat.

475. Al-Gamaa Al-Islamiya, Copts Compete in Minya, Daily News Egypt (Jan. 4, 2012), http://dailynewsegypt.com/2012/01/04/al-gamaa-al-islamiya-copts-compete-in-minya (noting Coptic population in Minya); Yasamine Saleh, Christian Governor Must Go, South Egypt Protesters Say, ReuTERs (Apr. 21, 2011), http://af.reuters.com/article/egyptNews/id AFLDE73K1NS20110421?sp=true (noting Coptic population in Qena); Ahmed Tolba, Egyptian Court Sends Christian Student to Jail for Insulting Islam, Al Arabiya News (Apr. 4, 2012), http://english.alarabiya.net/articles/2012/04/04/205477.html (noting Coptic population in Assiut).

476. ANalysis of the 2011 Parliamentary Electoral System, supra note 76, at 2.

477. For a discussion of the potential advantages proportional representation offers over a winner-take-all system, see AMY, supra note 472, at 69-79. 
as Minya, parties founded by former NDP members ${ }^{478}$ with deep roots to local tribes and large families did particularly well in the 2011 People's Assembly elections, winning fourteen out of twentyfour seats through proportional representation. ${ }^{479}$ Similarly, in tribal areas with large Coptic populations, parties such as the National Party, the Freedom Party, and the Egyptian Citizen Party placed Coptic candidates on the top of their voter lists, resulting in their election to parliament. ${ }^{480}$ In all, six Copts were elected and five appointed in the first post-revolution People's Assembly, and two were elected in the Shura Council. ${ }^{481}$

A comparison of the number of Coptic candidates participating in the People's Assembly elections in 2005 and 2011 highlights both the advantages and shortcomings of the current electoral system. In 2005, the then-ruling NDP nominated just ten Copts out of

478. Former NDP members founded ten different political parties following the dissolution of the NDP in 2011. See generally BAssiounI, supra note 133. Three of these parties won parliamentary seats: the National Party, founded by the late Talaat Al-Sadat, won six seats; the Freedom Party, founded by the sons of former NDP member Mohammad Mahmoud Ali Hussein, fielded over 500 candidates and won four seats; and the Egyptian Citizen Party, founded by former NDP member and construction magnate Alaa Hasaballah, won four seats. See Egyptian Elections: Preliminary Results, Jadalryya, http://www.jadaliyya. com/pages/index/3331/egyptian-elections_preliminary-results_updated\#Table_summary (last updated Jan. 9, 2012).

479. Egyptian Elections: Preliminary Results, supra note 478.

480. Copts, Islamists Face Off in Minya Run-Offs, Daily News Egypt (Jan. 11, 2011), http:/ /dailynewsegypt.com/2012/01/11/copts-islamists-face-off-in-minyas-run-offs. This strategy of appealing to Coptic voters by placing Coptic candidates at the top of party lists simultaneously dilutes the Coptic vote. Id. It entices Coptic voters to choose lists where Coptic candidates were already likely to win a seat and weakens regional parties such as the AlWafd Party, which traditionally enjoys strong Coptic support. Id. Al-Wafd Party won thirtyeight seats in the People's Assembly. SHarp, supra note 319, at 3. The Egyptian Bloc, an alliance between the Free Egyptians Party, Al-Tagammu Party and Egyptian Social Democratic Part, won thirty seats. Id. The Free Egyptians Party, which was founded by prominent Coptic businessman, Naguib Sawiris, had been expected to do well amongst Coptic voters. Bassiouni, supra note 133 , at 50 .

481. L. Lavi, People's Assembly Elections in Egypt Yield Victory for Muslim Brotherhood, Salafis; Down for Liberals, Left, and Revolutionary Youth, MiddeE E. MediA Res. Inst. (Feb. 3, 2012), http://www.memri.org/report/en/print6052.htm; see also Egypt MP Calls for More Women, Copts in Constituent Assembly, AHRAM ONLINE (Mar. 3, 2012), http://english.ahram.org.eg/ NewsContent/1/64/35914/Egypt/Politics-/Egypt-MP-calls-for-more-women,-Copts-in-constituen.aspx (quoting MP Amr Hamzawy calling for representation of women and Coptics in parliament). As of the writing of this Article, twelve Copts were appointed to the Shura Council. Ahmed Aboul Enein, Morsy Appoints 90 Members to Shura Council, Dally News EGYPT (Dec. 23, 2012), http://www.dailynewsegypt.com/2012/12/23/morsy-appoints-90members-to-shura-council. In the now dissolved People's Assembly, five Copts were appointed and two were elected. Tantawi Directly Appoints Five Copts to Parliament, EcypT INDEP. (Jan. 22, 2012), http://www.egyptindependent.com/news/tantawi-directlyappoints-five-copts-parliament. 
more than 839 candidates. ${ }^{482}$ As a consequence, the People's Assembly consisted of just six Copts, five of whom were appointed by President Mubarak and one was elected. ${ }^{483}$ In the 2011 People's Assembly election, 120 Coptic candidates ran for office, marking a significant increase from past years, yet still constituting a small number compared to the thousands of candidates who ran in that election. ${ }^{484}$ While the official results released by the HEC do not provide a breakdown by religious affiliations, political parties with strong Coptic support, like The Egyptian Bloc and Freedom Party, won thirty-four seats combined.485 In addition, the SCAF appointed five Copts, including two women, among its ten appointees to the People's Assembly. ${ }^{486}$

One particular reform could go a long way towards increasing Coptic representation in parliament-requiring that political parties list a Coptic candidate in the top three slots in districts where Copts comprise at least $10 \%$ of the general population. Even with this reform, the success of minority candidates still depends on political parties' commitments to include them in party lists. In a proportional representation system, political parties act as gatekeepers in the electoral process by choosing which candidates will run in elections. ${ }^{487}$ These recommendations also assume there are checks in place that prevent gerrymandering that dilutes the Coptic population in electoral districts. Because Muslim and Christian activists rejected a quota for Coptic candidates for fear it would foment sectarianism, mandatory ordering may be a more politically palatable alternative. ${ }^{488}$

482. Mike Elkin, Egypt's Christians Prepare for New Political Climate, N.Y. Times (Nov. 30, 2011), http://www.nytimes.com/2011/12/01/world/middleeast/egyptian-christians-getpolitical.html.

483. Abdel Monem Said Aly, Brandeis Univ., Crown Ctr. for Middle E. Studies, Prelude to Change: Egyptian Democratization, 2005, at 3 (2006).

484. Andre Azzam, A Thousand Parties Running in Egypt's First (Possibly) Free Elections, AsIA News (Nov. 23, 2011), http://www.asianews.it/news-en/A-thousand-parties-runningin-Egypt\%E2\%80\%99s-first-(possibly)-free-elections-23254.html.

485. The Egyptian Bloc is a political alliance between the liberal Tagaamu and Social Democratic Parties and the Free Egyptians Party, founded by prominent businessman Naguib Sawiris and favored by many Coptics. Bassiouni, supra note 133, at 26, 50. The AlWafd Party, traditionally supported by Coptics, placed third in the elections, winning thirty-eight seats. The New Al-Wafd Party, Geo. U. Berkley Ctr. for Religion, Peace, \& WORLD AFF., http://berkleycenter.georgetown.edu/resources/organizations/the-new-alwafd-party (last visited Jan. 9, 2013).

486. Tantawi Directly Appoints Five Copts to Parliament, supra note 481.

487. $I d$.

488. Egypt Christians Reject Quota Parliament Seats, supra note 454. 


\section{B. Bolstering the Independence and Transparency of the Elections Commissions}

While post-revolution amendments to laws governing the HEC are significant, ${ }^{489}$ additional reforms are needed to strengthen the HEC's independence and transparency. Removal of political appointments to the HEC, and use of judges, is a positive development; ${ }^{490}$ however, Law No. 38 of 1972 lacks express language stipulating that the HEC is a de jure independent entity. ${ }^{491}$ Despite the relative independence of the Egyptian judiciary, judges are still susceptible to political pressure post-revolution, as witnessed in the high profile prosecution of American non-governmental organization (NGO) workers in the spring of 2012.492 In that case, the workers were accused of stoking unrest with foreign funding and the court initially imposed a travel ban on the American defendants. ${ }^{493}$ The SCAF, acting in its capacity as the executive branch, coerced the presiding judges to lift the travel ban due to political pressure from the United States. ${ }^{494}$ Similarly, critics suspected undue SCAF influence on the SCC's decision to dissolve parliament as a broad remedy to its finding that some provisions of the parliamentary election law were unconstitutional. ${ }^{495}$

Thus, an HEC comprised solely of judges does not axiomatically make the HEC immune from political interference that could favor the dominant party. An alternative is to transform the HEC into an independent, non-governmental elections commission imparted with legal safeguards to protect against political interference. ${ }^{496}$ Such a body, used in other comparable developing nations, ${ }^{497}$ would lend legitimacy to the HEC as a neutral arbiter of

489. See supra Part III.B for a detailed discussion of the post-revolution changes to laws governing the HEC.

490. Democracy Reporting Int'L, Greater Transparency, supta note 141 , at 3.

491. Id.

492. Egypt Appoints New Judges for Non-Profit Trial, USA ToDAY (Mar. 4, 2012), http:// www.usatoday.com/news/world/story/2012-03-03/egypt-trial/53346840/1.

493. Id.

494. Ekram Ibrahim, Passing the Buck: Who Lifted the Travel Ban on Indicted Foreign NGO Workers?, Ahram Online (Mar. 6, 2012), http://english.ahram.org.eg/NewsContent/1/0/ 36149/Egypt/0/Passing-the-buck-Who-lifted-the-travel-ban-on-indi.aspx.

495. Nathan J. Brown, The Egyptian Political System in Disarray, Carnegie Endowment FOR INT'L PEACE (June 19, 2012), http://carnegieendowment.org/2012/06/19/egyptianpolitical-system-in-disarray/c073 (discussing the SCAF's political hand in the presidency, the constituent assembly, the parliament, and the SCC).

496. See, e.g., Press Release, Carter Ctr., Preliminary Statement, supra note 205.

497. Nations using an independent election commission include: South Africa, Australia, Canada, India, Indonesia, Nigeria, and Poland. See South Africa: Independent Electoral Commission, Electoral Inst. for Sustainability Democracy Afr., http://www.eisa.org.za/ 
the electoral process and shield judges from the trappings of undue political interference in their work.

\section{Judicial Elections Commissions Jeopardize the Judiciary's Independence}

Until 2007, Article 88 of the Egyptian Constitution mandated that members of the judiciary supervise elections. ${ }^{498}$ A 2007 constitutional amendment created slots for politically appointed nonjudicial members in the HEC and PEC. ${ }^{499}$ Predictably, NDP political appointees to these bodies controlled election supervision, which resulted in an unprecedented level of unchecked fraud and favoritism in the 2010 parliamentary elections. ${ }^{500}$ For these reasons, one of the first demands of reformists after the revolution was the removal of all political appointees from the elections commissions. ${ }^{501}$

Some Egyptian analysts regard the transition of the HEC and PEC from a quasi-judicial to a fully judicial body as a mixed blessing. ${ }^{502}$ On the one hand, the judiciary is one of the few state institutions that retained a degree of public confidence and credibility throughout the Mubarak years. ${ }^{503}$ On the other hand, judges have not been immune from the executive's attempts to monopolize

WEP/souiec.htm (last updated Feb. 2011); Overview of the AEC, Australian Electoral Cомм'N, http://www.aec.gov.au/about_aec/ (last updated Oct. 4, 2012); Sue Nelson, Election Law Enforcement: International Comparisons, Elections CAN. (Mar. 2003), http://www. elections.ca/res/eim/article_search/article.asp?id=59\&lang=e\&frmPageSize=; Electoral System of India, Indian Elections, http://www.indian-elections.com/electoralsystem/presidentandvicepresident.html (last visited Jan. 9, 2013); ACEH, INdON., European UNION Election Observation Mission (2006-2007), available at http://eeas.europa.eu/human rights/election_observation/aceh/final_report_en.pdf; INDEP. NAT'L ELECTORAL COMM'N, http://www.inecnigeria.org/ (last visited Jan. 9, 2013); Arab Spring Activists Observing Poland's Election, EGYPT INDEP. (Sept. 10, 2011), http://www.egyptindependent.com/node/ 503198.

498. Constitution of the Arab Republic of Egypt art. 88, 11 Sept. 1971, as amended May 22, 1980. The complete supervision of elections by judges was a result of a 2000 ruling by the SCC. Case no. 11/13/Constitutional Court (Egypt). After state officials supervising polling stations were convicted of fraud, the SCC held that only judges could supervise every aspect of the elections, including polling stations. CHAZL \& CHAZLI, supra note 19, at 27.

499. Chazli \& Chazli, supra note 19, at 26-27.

500. Int'L Found. for Electoral Sys., Elections in Egypt: Key Challenges for CredIBLE ANd COMPettrive Elections 6 (2011), available at http://www.ifes.org/Content/Publications/White-Papers/2011/ /media/Files/Publications/White\%20PaperReport/2011/ 2011_egypt_briefing_paper.pdf.

501. Brown, supra note 100.

502. See id.

503. Id. 
power; past presidents have deployed various tactics to co-opt the judiciary into their political agenda. ${ }^{504}$

The most powerful tool over the judiciary in the president's arsenal is the authority to appoint senior judges to the highest courts. Unchecked political appointment of senior judges who in turn appoint their deputies in a hierarchical judicial system compromises judicial independence. ${ }^{505}$ Indeed, Mubarak leveraged his appointment authority to select judges more sympathetic to the government's position in cases. ${ }^{506}$ In return for their loyalties, Mubarak renewed their senior appointments and assigned them to lucrative bureaucratic posts both during and after their judicial careers. ${ }^{507}$ It is also worth noting that until the issuance of Law No. 142 of 2006, there was no independent line item in the national budget for the judiciary. ${ }^{508}$ Instead, the judiciary's budget came out of the Ministry of Justice's budget, further compromising the independence of the judiciary. ${ }^{509}$

Similarly, judges appointed to the HEC or PEC receive attractive bonuses that may further compromise their impartiality with regard to the executive appointer. ${ }^{510}$ As further evidence of a compromised judiciary, judges are debating the writing of a new law of judicial organization that either amends or replaces, depending on the version proposed, the notorious Judicial Authority Law No. 142 of 2006 so as to allow the judiciary to institutionalize its own conception of full independence. ${ }^{511}$ Judges want a series of reforms

504. For example, President Nasser issued an executive decree that dismissed over 200 judicial officials, including the board of the Judges Association, some judges on the Court of Cassation, and other key positions in various parts of the judicial system. Moustafa, supra note 64, at 65 .

505. Chazli \& Chazli, supra note 19 , at 29.

506. Id. at 34 .

507. Id. at 32; see also KHALIL ET AL., supra note 100, at 16 (recommending transferring the authority to transfer, assign, or detail judges from the president to the High Judicial Council); Dina Zayed, Egypt's Judges Shoulder Hopes for Democracy, Al Arabiya News (Nov. 2, 2011), http://english.alarabiya.net/articles/2011/11/02/175076.html.

508. KHALIL ET AL., supra note 100 , at 16.

509. Id.

510. See id. at 24-25 (recommending transferring the authority to transfer, assign, or detail judges from the president to the High Judicial Council); Zayed, supra note 507.

511. Ahmed Zaki Osman, Judicial Reform Hits a Bump as Judges Propose Conflicting Draft Laws, EGYPT INDEP. (Sept. 9, 2011), http://www.egyptindependent.com/news/judicialreform-hits-bump-judges-propose-conflicting-draft-laws (reporting that Ahmed Mekki's draft law would amend Article 178 to transfer all the powers of the Minster of Justice to the Supreme Judicial Council, placing judicial affairs in the hands of judges whereas the minister is responsible solely for bureaucratic issues related to courthouses, such as construction, security, and non-judicial staff). 
that remove executive branch control of their affairs and institute a more extensive separation of powers. ${ }^{512}$

Post-revolution, many of these presidentially appointed senior judges are on the HEC and PEC. In 2009, pursuant to Article 5 of Law No. 1979, Mubarak appointed Faruq Sultan as the head of the SCC, who also chaired the PEC. ${ }^{513}$ Sultan's service in the exceptional military courts, state security courts, the "court of ethics," placed him among the group of judges beholden to the regime. ${ }^{514}$ Consequently, Sultan's appointment was seen as a political maneuver by Mubarak to assure transfer of the presidency to his son. ${ }^{515}$

Similarly, the Justice Minister appoints, from among the judges of the appeals courts, the presidents of the High Courts with the approval of the High Judicial Council. ${ }^{516}$ Meanwhile, the most senior judges on the High Judicial Council are appointed by the president. ${ }^{517}$ This concentration of executive power in the appointment of the most influential judges raises questions as to the independence of the judiciary as a whole, notwithstanding the independence of some individual judges.

Because the president's appointment authority has not changed after the January 25 Revolution, except as it relates to the appointment of the chair of the SCC, ${ }^{518}$ no legal mechanism prevents future presidents from using their authority to influence the HEC and PEC to their party's advantage. ${ }^{519}$ If Egyptians decide to retain fully judicial elections commissions, then they should remove the president's appointment powers altogether and allow the judges to internally determine who heads the highest courts based on merit

512. Brown, supra note 119 ("Even the indirect ways of influencing judges, such as doling out attractive secondments, would be placed in judicial rather than executive branch hands. The effect would be to make the judiciary as a body far more autonomous in terms of administration, budgeting, and personnel.").

513. David D. Kirkpatrick, New Turmoil in Egypt Greets Mixed Verdict for Mubarak, N.Y. TImes (June 2, 2012), http://www.nytimes.com/2012/06/03/world/middleeast/egypthosni-mubarak-life-sentence-prison.html (reporting that lawyers and victims outside the courtroom chanted, "The people want to cleanse the judiciary," upon hearing Mubarak's sentence); Mark Lynch, Why Did the Egyptian Regime Appoint a New Chief Justice?, ForEıGN PoL'y (July 21, 2009), http://lynch.foreignpolicy.com/posts/2009/07/21/why_did_the_ egyptian_regime_appoint_a_new_chief_justice.

514. In contrast to appointing other members of the SCC, the president has unfettered discretion to appoint the president of the SCC. Chazli \& CHazli, supra note 19, at 30.

515. Id.

516. Id. at 31 .

517. Id. at 29.

518. Mona El-Nahhas, How Will It End?, AL-Ahram WeEkıy (Oct. 25-Nov. 31, 2012), http://weekly.ahram.org.eg/2012/1120/eg4.htm.

519. See KHALIL ET AL., supra note 100, at 11, 15 (concluding that judicial independence requires that judges alone choose the heads of judicial councils and courts). 
and seniority. In the alternative, the president's judicial appointments should be subject to confirmation by the People's Assembly.

Regardless of the scheme adopted, the judiciary's legitimacy hinges on the fairness and transparency of the elections monitoring process. As the vice president of the Court of Cassation aptly noted, " $[\mathrm{t}]$ he Judiciary must operate without any external influence, whether direct or indirect, that may weaken the resolve of its members and lead them away from truth, whether through inducement or compulsion, enticement or intimidation, threats or promises." 520

\section{A Nontransparent Deliberation Process}

Another significant flaw in the current HEC and PEC is their lack of operational transparency. The HEC fails to consult political parties and other electoral stakeholders before making decisions that affect elections. ${ }^{521}$ For example, the HEC failed to consult stakeholders before promulgating rules regulating the process for registering party lists and coalitions. ${ }^{522}$ In the 2011 elections, this approach was at odds with the principle of open elections in which citizens are the central actors for formulating electoral rules. ${ }^{523}$ At the very least, citizens should have a meaningful opportunity to comment on forthcoming changes to election rules before a final agency decision is issued. ${ }^{524}$

Egypt's laws, unlike those of countries such as Palestine, do not mandate transparent elections. ${ }^{525}$ In fact, some of the provisions of Law No. 73 of 1956 restrict transparency. ${ }^{526}$ For example, Article 3(bis) (d) stipulates that "[d]eliberations of the HEC shall be secret," while Article 35 states that the deliberations of the vote counting committees "shall take place behind closed doors." 527 In contrast, supervisory bodies in other countries generally permit stakeholders, the media, and observers to attend these sessions as it enhances public confidence. ${ }^{528}$ As such, legislative reforms to Law No. 73 of 1956 are necessary to promote transparency, bolster the

520. Id. at $21-22$.

521. Democracy Reporting Int'L, Greater Transparency, supra note 141, at 2.

522. Id. at 3 .

523. Id.

524. Id.; see also Nat'l Democratic Inst., Colloguium on African Elections: Best Practices and Cross-Sectoral Collaboration 20 (2009) [hereinafter Colloquium on AFriCAN ELECTIONS] (citing similar recommendations for African governments).

525. Democracy Reporting Int'l, Greater Transparency, supra note 141 , at 3 \& n.7.

526. Id.

527. Id.

528. See id. 
HEC's independence, and educate voters about their rights in elections.

In the case of the PEC, post-revolution reforms leave much to be desired. Article 28 of the Interim Constitutional Declaration bars the right to appeal a PEC decision, thereby vesting the PEC with unchecked authority and immunity from erroneous decisions. ${ }^{529}$ Reformers are rightfully concerned with avoiding a repeat of Mubarak-era concentrations of power in a few judges who subjectively rule in favor of a particular party. ${ }^{530}$ Such concerns are heightened by allegations against then presiding chair of the PEC, Farouk Sultan, of improperly supervising the 2009 elections of the Lawyers' Syndicate to prevent Islamists from winning. ${ }^{531}$ Similarly, the SCAF pressured the Court in March 2012 to reverse its ruling barring American NGO employees from leaving Egypt pending their trial for violating the NGO law. ${ }^{532}$ To the extent such concerns about Sultan and other judges on the PEC are valid, similar partiality could be exercised in presidential elections. Irrespective of the validity of the specific charges above, concerns over the inability to appeal PEC rulings are compelling. Therefore, new election laws should be amended to provide a right of appeal to the Supreme Court of Cassation.

\section{The Need for an Independent Elections Commission Subject to Judicial Review}

Unless the law is reformed to curb the president's authority to appoint judges, an independent, non-judicial entity may be a better option to preserve the legitimacy of elections. In addition to the problems associated with the appointment process, judges are not well suited for the tedious and politically charged tasks of supervising polls, counting ballots, and announcing election

529. See Mara Revkin, Thousands of Islamists Rally in Tahrirto Denounce Former Regime Candidates, Atlantic Colincil (Apr. 13, 2012), http://www.acus.org/egyptsource/top-newsthousands-islamists-rally-tahrir-denounce-former-regime-candidates (reporting protests that ensued after the SCAF's revision of Article 28 of the Constitutional Declaration because it stated that the PEC was not subject to judicial oversight and was immune to appeal); Gamal Essam El-Din, Sting in the Tail, Al-Ahram WeEkly ONLine (Apr. 25-May 1, 2012), http://weekly.ahram.org.eg/2012/1095/sc3.htm.

530. See Elbaradei Slams Immunity for Presidential Elections Commission, EGYPT INDEP. (Mar. 20, 2012), http://www.egyptindependent.com/news/elbaradei-slams-immunity-presidential-elections-commission; see also Kochan, supra note 33, at 906 (identifying the risk that a post-nonviolent revolution regime may be very similar to the old regime).

531. See, e.g., El-Din, Legitimacy, supra note 384.

532. But see Ibrahim, supra note 494 (noting no government entity claimed responsibility for the reversal). 
results. ${ }^{533}$ Requiring them to engage in fundamentally political activities undermines their role as neutral arbiters detached from politics. Accordingly, Egypt should seriously consider creating an independent elections commission whose decisions are subject to independent judicial review.

The challenge, however, lies in ensuring the commissioners retain their independence from undue legislative or executive interference in light of Egypt's checkered record. Depending on the model selected, Egypt can avoid repeating past mistakes that impeded past elections from being free and fair. Egypt should consider the following five models that scholars have identified for independent elections commissions: (1) the independent model; (2) the electoral branch model; (3) the mixed model; (4) the executive model; and (5) the judicial model.

The independent model would establish the election commission as independent of the executive and with its own budget. ${ }^{534}$ The electoral model would designate the commission as a constitutionally-recognized separate branch of government whose members are appointed by the executive or legislative branch. ${ }^{535}$ The mixed model would involve an independent board that determines policy and an executive department that implements policy under the supervision of the board. ${ }^{536}$ An election commission following the executive model, on the other hand, is directed by a cabinet minister as part of the executive branch with local government officials acting as agents of the central commission. ${ }^{537}$ Under the judicial model, the election commission would be closely supervised by and ultimately responsible to a special electoral court. ${ }^{538}$

The type of model best suited for Egypt depends on its unique political circumstances and its history of authoritarianism. That said, a number of factors will be essential to bolstering the commission's independence. First, the legal and financial framework underpinning the election commission should guarantee its independence. ${ }^{539}$ Second, the executive branch should select commissioners through an inclusive and transparent process. Third, the elections commission must regularly provide accurate information

533. Brown, supra note 119.

534. Alan Wall et al., Int'l INst. for Democracy \& Electoral Assistance, Electoral Management Design: The International IDEA Handbook 6 (2008).

535. See id.

536. Id.

537. Id.

538. See id. at 6-7.

539. Colloquium on African Elections, supra note 524, at 4. 
on the electoral process to the public. In particular, the commission should be proactive in ensuring accessibility to marginalized groups such as the disabled, youth, and women. Finally, the elections commissions must expeditiously and transparently count, tabulate, and announce election results, which should be amenable to challenge through a complaint process that is timely, transparent, and accessible to all voters. ${ }^{540}$ Combined, these good practices would contribute to a legitimate, credible, and independent elections commission.

As a case study, Egypt should look to Ghana's experience. Ghana's election commission has become an internationally recognized exemplar based on its supervision of a series of free and transparent elections. ${ }^{541}$ Ghana uses the mixed model wherein the president appoints the commission's seven commissioners in consultation with the State Council of Ghana, a select group of elders who advise the president on national issues. ${ }^{542}$ The electoral commission is a corporate entity with the capacity to acquire and own property and to sue and be sued. ${ }^{543}$ The commissioners meet regularly to make policy that is implemented by the chairman and the commission's permanent staff. ${ }^{544}$ Ghana's electoral commission's primary responsibilities include: 1) compiling and updating the register of voters; 2) demarcating the electoral boundaries for national and local government elections; 3 ) conducting and supervising all public elections and referenda; 4) educating the people on the electoral process; and 5) leading initiatives to increase voter registration. ${ }^{545}$

Not only is Ghana's independent elections commission subject to judicial review, but it also encourages and facilitates participation in the elections process from the entire country. ${ }^{546}$ Ghana's election commission effectively engages all election stakeholders by cultivating standing relationships with the media, political candidates, political parties, religious leaders, security services, civil society organizations, etc. ${ }^{547}$ The election commission holds regular meetings to reach a consensus and to discuss and review issues in

540. See id. at 21.

541. See id. at 1-2.

542. Constitution of the Fourth Republic of Ghana 1992, ch. 43, 70.

543. Electoral Comm'n of Ghana, Elections 2004: Ghana's Parliamentary and Presidential Elections 7 (2005).

544. Id. at 5 .

545. Id. at 3.

546. Colloquium on African Elections, supra note 524, at 5.

547. Id. 
light of the stakeholders' opinions on national interest (for example, on how to organize the elections to eliminate violence) ${ }^{548}$ The commission also organized candidate debates, working with the media to determine debate questions based on the public's input and to ensure broad coverage of the debates. ${ }^{549}$ These efforts create a universal feeling of collaboration and accountability that increases the credibility and transparency of the electoral process, thereby decreasing tension and violence during elections.

Ghana also has a coalition of election observers and conducts a statistical analysis of election results-known as parallel vote tabulation-that prevents fraud and helps the public accept the announced results, especially when one candidate wins by a close margin. ${ }^{550}$ Egypt must take measures to re-legitimize the elections process, and it can do so by increasing communication between, and participation of, all stakeholders affected by the election, like Ghana's elections commission has done. ${ }^{551}$

While the transition away from a judicially run elections commission warrants more study and internal debate within Egypt, an independent commission with its own budget and independent staff is worth serious consideration. Egypt has a strong interest in preserving the independence and legitimacy of its judiciary. Keeping judges out of politics and the elections process is a necessary prerequisite in meeting that objective.

\section{Training Judges and Educating Voters}

In contrast to Egypt's positive post-revolution amendments to election laws, one adverse change is particularly noteworthy. Postrevolution, the HEC no longer has the authority to educate voters about the electoral process and their rights within it. ${ }^{552}$ In a highly complex and tedious voting process, voter education is paramount to ensure long-term voter turnout. For example, in both chambers' elections, voters are required to cast at least three votes on

548. Id. at 7 .

549. Id. at 7-8.

550. Id. at 11 (highlighting how helpful statistical analysis was in the legitimizing the closeness of the margin in Ghana's 2008 elections).

551. Id.

552. Press Release, Carter Ctr., Preliminary Statement, supra note 205; see also Final Phase Completes Egyptian People's Assembly Elections, InT'L Republican Inst. (Jan. 19, 2012), http://www.iri.org/news-events-press-center/news/final-phase-completes-egyptian-peoples-assembly-elections (recommending that the HEC make an effort to educate voters to ensure that illiterate voters exercise their right to vote). 
two ballot papers. ${ }^{553}$ They must also split their votes between party candidates at the local, district, and national level. ${ }^{554}$ By design, many races go to a second round run-off, which leads to voter fatigue and waning voter participation, as evinced in the second round of the 2011 People's Assembly elections, where voter turnout dropped precipitously. ${ }^{555}$ For these reasons, either the HEC or another body needs authorization and sufficient funding to proactively educate voters, $33 \%$ percent of whom are illiterate, ${ }^{556}$ on how to maneuver through Egypt's complicated election process. ${ }^{557}$

Likewise, the Egyptian government must inform voters of the process for submitting electoral complaints. In the 2011 People's Assembly elections, many Egyptians did not know how to access complaint mechanisms, especially in the early election stages. ${ }^{558}$ Consequently, the deadline for submitting complaints was extended by the courts, delaying the release of final election results. ${ }^{559}$ Solving this problem requires either restoring the HEC's authority or appointing another government entity to educate voters about the electoral process and its complaint procedures. Otherwise, voters have no centralized government entity to turn to for comprehensive information about the elections process, applicable laws, and their rights as voters. While critics of Egypt's bureaucracy raise legitimate concerns about its notorious record for poor public service, ${ }^{560}$ a jurisdictional void for voter education makes voters worse off.

553. Analysis of the 2011 Parliamentary Electoral. System, supra note 76, at 11.

554. Id.

555. See David D. Kirkpatrick, Turnout Falls as Egypt Casts Runoff Ballots, N.Y. Times (Dec. 5, 2011), http://www.nytimes.com/2011/12/06/world/middleeast/egyptian-runoffs-losing-momentum.html; Ernesto Londono \& William Wan, American Workers for Pro-Democracy Organization in Cairo Take Sheller at U.S. Embassy, WASH. Post (Jan. 29, 2012), http://www. washingtonpost.com/world/middle_east/low-turnout-in-second-phase-of-egyptian-vote/ 2012/01/29/gIQAIpLFaQ_story.html; see also, e.g., Press Release, Carter Ctr., Preliminary Statement, supra note 204 (noting the voter turnout for the People's Assembly exceeded $55 \%$, while the Shura Council elections had less than a $14 \%$ turnout in the first round and less than $7 \%$ turnout in the runoff rounds).

556. Egypt Statistics, UNICEF, http://www.unicef.org/infobycountry/egypt_statistics. html (last updated Feb. 21, 2003) (indicating a 66\% adult (individuals over age fifteen) literacy rate in a population of over 81 million).

557. See, e.g., Press Release, Carter Ctr., Preliminary Statement, supra note 204.

558. Id.

559. Id.

560. See Levinson, supra note 237 (mentioning the unreformed, unrestructured state bureaucracy's ability to make one outcome more likely than others without directly dictating outcomes); CHAZLI \& CHAZLI, supra note 19, at 60 (noting that people seeking remedies pushed for use of the legal system because the state bureaucracy is dysfunctional). 
Moreover, the complex and protracted nature of parliamentary elections requires administrators to fully understand the new electoral system in order to competently perform their oversight responsibilities. ${ }^{561}$ With the reinstatement of full judicial supervision of the elections, judges are involved in the electoral process at various levels. They serve as commissioners on the HEC, supervise polling stations, and manage the candidate application and registration process. ${ }^{562}$ As such, judges and election administrators need proper training in supervising elections. ${ }^{563}$ At least one international election-monitoring group found the counting process in the 2011-2012 parliamentary elections chaotic and inconsistent across districts, in large part due to an absence of clear procedures and training for supervising judges. ${ }^{564}$ Voters commonly reported long lines and overcrowded voting precincts caused by a lack of logistical coordination between supervising judges and security personnel. ${ }^{565}$ Rather than argue against assigning a government agency to educate voters and train elections administrators, time is better spent assigning such an agency and improving its performance.

\section{Conclusion}

In light of Egypt's checkered history with legal reform, it is too soon to tell if the post-revolution reforms on paper will translate into meaningful reforms in practice. ${ }^{566}$ Of particular concern is the future role of the new dominant party, the Muslim Brotherhood. If the past is prologue, Egyptians should remain vigilant in preventing the Muslim Brotherhood from becoming the new NDP whereby its control over the levers of power in the executive and legislative branch make democracy unattainable for Egyptians. ${ }^{567}$

561. Chazli \& Chazli, supra note 19 , at 67.

562. Id. See Part III.B for a detailed discussion of judges' roles in the HEC.

563. CARTER CTR., supra note 299 , at 11 (reporting that some judges were neither properly nor uniformly trained in elections monitoring and ballot counting prior to the parliamentary and presidential elections).

564. Press Release, Carter Ctr., Carter Center Witnessing Mission for Egypt's People's Assembly Elections Executive Summary of Findings (Jan. 13, 2012), http://www. cartercenter.org/news/pr/egypt-011312.html.

565. Id.

566. See, e.g., AMNESTY INT'L, supra note 187, at 2 (noting that Egyptian women have had equal rights on paper since the 1956 Constitution, however, those rights have yet to be realized in practice).

567. Moustafa, supra note 64, at 78 (quoting Mustafa Khalil, prime minister from Oct. 1978-May 1980, as saying, "But a major problem was that the NDP, having the majority in the People's Assembly, could push through any legislation it wanted and change the previous laws."). 
Rather than wait until the Muslim Brotherhood, or any other dominant party, manipulates the laws to its advantage to pursue perpetual dominance, Egyptians should make it clear their votes must be earned and any improper meddling with the electoral system is political suicide.

Towards that end, Egypt needs more structural reforms to promote free and fair elections monitored by independent supervisory bodies. Going forward, the HEC and PEC must be restructured to ensure independent oversight of parliamentary and presidential elections. Recent moves to depoliticize the composition of the $\mathrm{PEC}$ and to open the vote-tallying process to third party monitors and party representatives are positive steps towards boosting the credibility of elections results. More importantly, however, the PEC and HEC must have a budget separate from the executive and legislative branch and their decisions must be subject to judicial review.

The underrepresentation of women and minority groups in parliament must also be addressed. ${ }^{568}$ Post-revolution legislative reforms fall short of establishing a transparent and accessible electoral system that promotes women and minority representation in government. Specifically, the SCAF revoked the sixty-four-seat female candidate quota in the People's Assembly but did not replace it with a viable alternative to promote female political participation. This resulted in a significant decrease in women in the 2012 parliament. ${ }^{569}$ As such, a women's quota should be reinstated to ensure greater women representation in parliament. In the alternative, all political parties should be required to alternate between male and female candidates on their party list.

Likewise, political parties must engage Coptic candidates and, in districts where Copts comprise more than $10 \%$ of the population, parties should be required to place a Copt in one of the top three slots on their party list. This measure should be implemented simultaneously with prohibitions on gerrymandering districts to dilute the Coptic vote. Without such remedial measures, Copts will continue to be underrepresented in the Egyptian Parliament.

By removing control over elections monitoring from the executive branch and placing it squarely under the purview of the judici-

568. See, e.g., Press Release, Carter Ctr., Preliminary Statement, supra note 205 (recommending a quota that ensures at least $30 \%$ of the parliament consists of women); see also Kochan, supra note 33, at 904 (explaining that it is essential to protect the rights of minorities, especially when building a constitution).

569. Garcia-Navarro, supra note 256. 
ary, the post-revolution amendments shift Egypt's electoral framework towards a more transparent and independent process. That said, Egyptians should transition the HEC from a purely judicial entity to an independent, non-governmental elections commission. Despite Egyptians' trust in their judiciary, judges have not been immune from improper executive interference in the past. Through appointments of senior judges to the highest courts and assignments to lucrative bureaucratic posts, the executive branch can compromise the independence of the judiciary. Moreover, placing judges in the line of fire for political disputes exposes them to politicization and a loss of independence. ${ }^{570}$

To the extent the HEC and PEC will remain judicially run, supervising judges need better training to manage the electoral process and coordinate with security personnel to ensure transparent and organized voting. At the grassroots level, voters must be educated about the electoral process and the procedures for filing complaints about voting irregularities. Increased voter awareness is a valuable mechanism for protecting against fraud and other election irregularities. Furthermore, the rule-making procedures of the HEC should be more transparent, allowing input from electoral stakeholders such as political parties and civil society organizations before new rules are issued. Amendments to Articles 3(bis) and 35 of Law No. 73 of 1956 requiring the vote tallying process be made open to third-party monitors and party representatives would go a long way towards this end.

Furthermore, the SCAF's adoption of a mixed proportional party representation and independent candidate winner-take-all system marks another substantial advance in the promotion of civic engagement by minority groups, when compared to the previous electoral regime. The mixed system using a "closed list" process simultaneously weakens the significance of individual candidates, including NDP partisans, and empowers political parties to effectively determine who will stand in parliamentary elections. ${ }^{571}$ The lack of a vibrant political sphere over the past thirty years makes it likely that, in the short-term, well-organized Islamist parties will fare well under proportional representation, and well-connected citizens and political partisans from the previous regime will win

570. For example, prior to 2007, judges oversaw elections but even then the executive branch manipulated the judiciary using the judges' prestige to legitimate sham elections, causing a controversy within the Judge's Club. Brown, supra note 119.

571. Egyptian Military Amends Controversial Election Law, supra note 234. 
most of the independent candidate seats. ${ }^{572}$ Indeed, the results from the 2011 election of the People's Assembly confirm this outcome. Egypt's Islamist parties, the Muslim Brotherhood's Freedom and Justice Party and the Salafi Al-Nour Party, ${ }^{573}$ combined to secure 356 seats, or $71.47 \%$ of all seats, in the People's Assembly. ${ }^{574}$ Additionally, former members of Hosni Mubarak's NDP running as independent candidates, won fifteen seats, or $10 \%$ of all seats allotted through the independent candidate winner-take-all system. ${ }^{575}$ Thus, this mixed election model has its limitations in bringing in new political players into the fold.

Notably, many ambiguities in the electoral laws remain unresolved. For instance, while the amended version of Law No. 38 of 1972 envisions the formation of political coalitions, it does not provide any detail on how coalitions can be registered. ${ }^{576}$ Law No. 38 of 1972 also fails to specify how votes garnered by a coalition will be distributed among the coalition's various political parties. ${ }^{577}$ This information is necessary to determine which specific parties meet the minimum number of votes needed for a parliamentary seat. Without a clear and accessible coalition-forming process, smaller parties are disadvantaged because they rely on coalitions to pool their resources to compete against the larger parties for seats in the parliament. ${ }^{578}$ Thus, political disputes among coalition members seeking a seat in the parliament are inevitable. In the end, Law No. 38 deters formations of coalitions, thereby disfavoring smaller parties.

One year after their historic revolution, Egyptians have made great strides towards a transition from entrenched authoritarian-

572. BAssioun,, supra note 133, at 16; see also Kochan, supra note 33, at 906 (stating that after a nonviolent revolution, too often the replacement regime is similar to the displaced regime).

573. For more information about the Muslim Brotherhood's Freedom and Justice Party, see Kristen Stilt, "Islam Is the Solution": Constitutional Visions of the Egyptian Muslim Brotherhood, 46 Tex. INT'L L.J. 73 (2010). For more information about the Salafi Al Nour Party, see Jonathan Brown, Salafis and Sufis in Egypt, Carnegie Endowment for INT'L Peace (Dec. 2011), http://carnegieendowment.org/2011/12/20/salafis-and-sufis-in-egypt/8fj4.

574. Agence France-Presse, Egypt's Islamists Win Parliamentary Elections, Raw STORY (Jan. 21, 2012), http://www.rawstory.com/rs/2012/01/21/egypts-islamists-win-parliamentaryelections.

575. Aya Batrawy, Egypt Elections 2012: Islamists Secure 75 Percent of Parliament, HuFFINGTON Post (Jan. 21, 2012), http://www.huffingtonpost.com/2012/01/21/egypt-elections-2012-islamists_n_1220801.html.

576. Law No. 38 of 1972 (Concerning the People's Assembly), Al-Jarida Al-Rasmiyya, 28 Sept. 1972 (Egypt).

577. Id.

578. Id. art. 15 . 
ism to a democracy uniquely tailored to Egyptian cultural and religious norms. The key to their success will be whether postrevolution reforms are structural, in the sense that they produce a complete upheaval of a corrupt political system as called for by most Egyptians, or merely superficial changes under the false guise of reform. While it is still too soon to predict the outcome, one thing has become quite clear-future political leaders who seek to impose authoritarianism do so at the risk of triggering another revolution. 


$$
\text { . }
$$

